\title{
Satellite-Derived Sea Surface Temperature, Mesoscale Variability, and Foraminiferal Production in the North Atlantic
}

by

\section{Carl Martin Wolfteich}

\author{
B.A., Hamilton College (1980) \\ M.A., Rice University (1982)
}

Submitted to the Massachusetts Institute of Technology/

Woods Hole Oceanographic Institution

Joint Program in Oceanography and Oceanographic Engineering in partial fulfillment of the requirements for the degree of

\author{
Master of Science in Oceanography \\ at the \\ Massachusetts Institute of Technology \\ and the \\ Woods Hole Oceanographic Institution
}

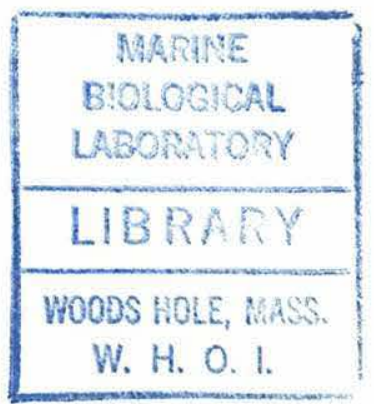

February 1994

(C)Carl M. Wolfteich, 1994

The author hereby grants to MIT and WHOI permission to reproduce and distribute copies of this thesis document in whole or in part.

Signature of Author .............ب

Joint Program in Oceanography and Oceanographic Engineering Massachusetts Institute of Technology/

Woods Hole Oceanographic Institution

Certified by $\ldots \ldots \ldots \ldots \ldots \ldots \ldots \ldots$.
/
Dr. Wifliam B. Curry
Thesio Supervisor

Accepted by

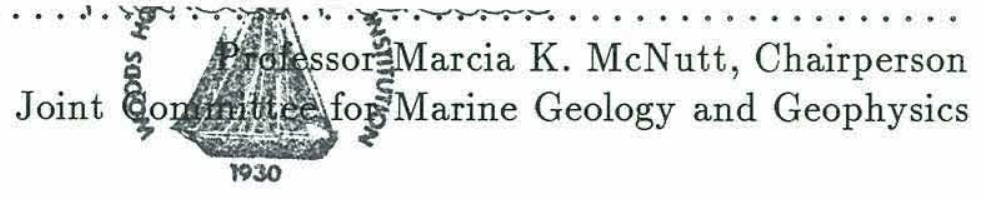




\title{
Satellite-Derived Sea Surface Temperature,
}

\author{
Mesoscale Variability, and Foraminiferal
}

Production in the North Atlantic

by

\author{
Carl Martin Wolfteich
}

\author{
Submitted to the Massachusetts Institute of Technology/ \\ Woods Hole Oceanographic Institution \\ Joint Program in Oceanography and Oceanographic Engineering \\ in partial fulfillment of the requirements for the degree of \\ Master of Science in Oceanography
}

\begin{abstract}
Planktonic foraminiferal flux was collected at four sediment trap locations spanning a $34^{\circ}$ latitude range in the North Atlantic during 1988-1990. Satellite-derived sea surface temperature (SST) and CTD data were integrated with time-corrected flux data to determine the effects of seasonal hydrographic changes on foraminiferal production and species succession in surface waters. The thermal structure of the upper water column controls foraminiferal production by regulating levels of phytoplankton production and by directly influencing the preferred temperature habitats of individual species in the community. Sediment traps deployed at the two southern sites $\left(34^{\circ} \mathrm{N}\right.$ and $48^{\circ} \mathrm{N}$ ) were part of the U.S. Joint Global Ocean Flux Study (JGOFS) and were located in regions influenced by upwelling events induced by mesoscale eddy activity.

The timing of maximum foraminiferal production at each trap location coincides with the northward progression of the spring bloom in the North Atlantic. The magnitude of total flux during bloom periods varies considerably with location and is positively correlated with the amount of primary productivity in surface waters. Foraminiferal production is highest at JGOFS 48 and probably results from the greater influence of mesoscale variability in this region on local hydrographic conditions. The upwelling associated with cyclonic cold-core eddies appears to be an effective mechanism for increasing local foraminiferal production in the North Atlantic by enhancing food availability. The preferred production of individual species during upwelling periods may depend on the vertical distribution of chlorophyll in the water column. Seasonal variation in SST is also an important factor controlling the relative abundance of species with preferred thermal habitats. A distinct seasonal species succession occurs at both JGOFS sites but is absent at higher latitudes due to
\end{abstract}


decreases in both faunal diversity and seasonal temperature variations with increasing latitude in the North Atlantic.

Foraminiferal flux data, expressed in terms of relative abundance, is the best direct method of comparing species distributions of living populations with fossil assemblages in the sedimentary record. Preferred temperature ranges for G. ruber, $G$. bulloides, and $N$. pachyderma are estimated in this study. The tolerance limits for these species and other ecological inferences derived from these flux data may prove useful for paleoceanographic reconstruction in deep-sea cores. Future studies will be necessary, however, to establish the consistency of these results among different ocean basins.

Thesis Supervisor: Dr. William B. Curry 


\section{ACKNOWLEDGMENTS}

First and foremost, I would like to thank Bill Curry for his advice and helpful insight throughout the development of this research. My experience at WHOI, though tortuous at times, was enriched by my associations with Bill and others who offered their helpful support along the way. I was fortunate to work in a lab with someone as knowledgeable and efficient as Rindy Ostermann, who processed some of the initial samples and whose expertise at species identification proved invaluable to this project. Javier Escartin was very helpful in answering questions about quantitative data analysis using Matlab, besides being a supportive office mate. I am grateful to Mike Caruso for his computer programming skills that facilitated the display and analysis of satellite imagery in my research. Many thanks go to Dave Schneider for his helpful comments on this and other manuscripts written at WHOI, as well as his friendly support when the days seemed darker. I also greatly appreciate the computer assistance of Dan Lizarralde, a fellow surfer, whose help came at a time when I most needed it. I would also like to thank Glenn Jones for his guidance and support during the latter stages of my term in the Joint Program. Finally, a special thanks to Stephanie Geller for helping on the Appendix tables and for her continued personal encouragement. The AVHRR satellite data used in this study were obtained from the NASA Physical Oceanography Distributed Active Archive Center at the Jet Propulsion Laboratory, California Institute of Technology. This research was funded by National Science Foundation Grant No. ATM-9115619. 


\section{TABLE OF CONTENTS}

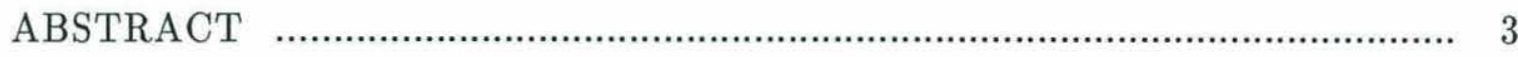

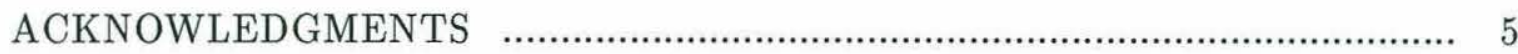

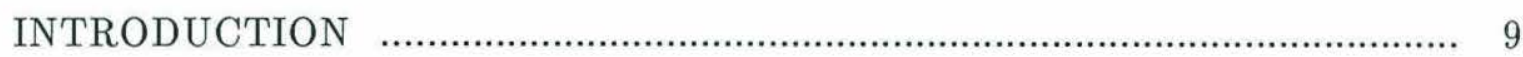

BACKGROUND

Seasonality in Foraminiferal Production .................................................. 10

Mesoscale Variability ......................................................................... 13

Deep Chlorophyll Maximum ..................................................................... 14

METHODS

Sample Processing .............................................................................. 15

Time Correction Factors ...................................................................... 16

Satellite (AVHRR) Data …….................................................................. 17

RESULTS

JGOFS Stations

High Latitude Stations ...................................................................... 29

Species Diversity ............................................................................... 36

DISCUSSION

Total Foraminiferal Flux

and the Spring Bloom ………............................................................. 36

Mesoscale Variability at JGOFS 34 and 48 .............................................. 43

Species Succession and

Preferred Production Periods .................................................................. 48

TEMPERATURE RANGES AND

ECOLOGY OF INDIVIDUAL SPECIES

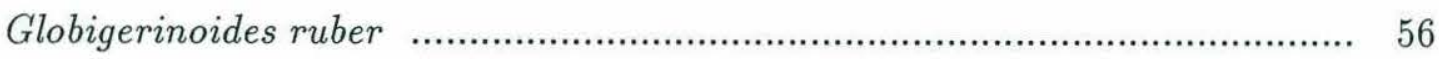

Globigerina bulloides ...................................................................... 58

Neogloboquadrina pachyderma $\quad$............................................................... $\quad 59$

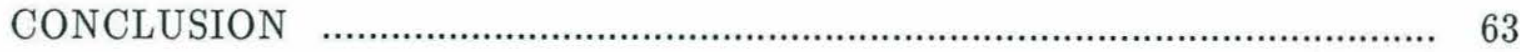

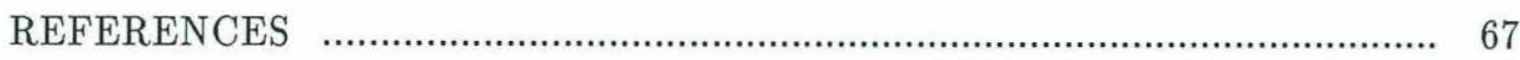

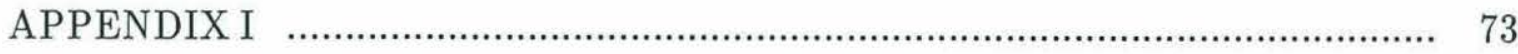

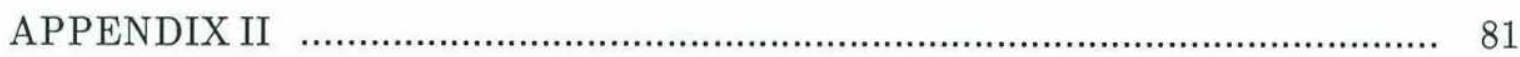




\section{INTRODUCTION}

Fossil assemblages of planktonic foraminifera are utilized extensively by paleoceanographers in the reconstruction of Late Quaternary marine environments. The distribution patterns of living planktonic foraminifera (Bé and Tolderlund, 1971; Bé, 1977; Hemleben et al., 1989) show that modern species each live within certain tolerance ranges of environmental conditions. Seawater temperature is recognized as one important factor controlling the geographic and seasonal distribution of foraminiferal species in surface waters (Tolderlund and Bé, 1971; Bé, 1977; Deuser et al., 1981; Fair-

banks et al., 1982; Thunell et al., 1983; Thunell and Reynolds, 1984; Reynolds and Thunell, 1985; Deuser, 1987; Thunell and Honjo, 1987; Sautter and Thunell, 1989, 1991; Thunell and Sautter, 1992), and on this basis, fossil distributions of foraminifera have been used to reconstruct past sea surface temperature (SST) distributions. $\mathrm{Nu}-$ trient supply and food source availability are also important ecological variables that influence the growth and survival of planktonic species and are considered to be a function of local hydrographic conditions (Valiela, 1984; Hemleben et al., 1989). By determining the response in foraminiferal production to seasonal changes in the thermal structure of surface waters, we can better understand variations in foraminiferal flux which are eventually incorporated into the sedimentary record.

Automated sediment traps are a reliable means of directly measuring deep-sea biogenic flux by collecting time-series samples over a predetermined period of time (Honjo et al., 1982). Sediment trap data have been used in previous work (Deuser et al., 1981; Thunell et al., 1983; Thunell and Reynolds, 1984; Deuser, 1986; Sautter and Thunell, 1989, 1991; Thunell and Sautter, 1992) at single locations to relate the seasonal variability in flux of planktonic Foraminifera to local hydrographic conditions. In this study, seasonal vertical flux variations of Recent planktonic foraminifera are documented during 1988-1990 at four sediment trap locations spanning a $34^{\circ}$ latitude range in the North Atlantic (Figure 1). Four of the five biogeographic zones delineated by Bé and Tolderlund (1971) in the North Atlantic are represented here by the sampling stations. The broad geographic range of these flux data allows the effects of seasonality to be quantified in both a spatial and temporal sense. Satellite-derived sea 
surface temperatures, synchronous with trap deployment, are integrated with the flux data to determine effects of seasonal temperature changes on foraminiferal production and species succession in surface waters. Hydrographic data acquired during the JGOFS (Joint Global Ocean Flux Study) North Atlantic Bloom Experiment (NABE) during 1989 were also utilized in this investigation and provided insight into possible mechanisms causing some of the flux variations in concurrent trap data.

Present upwelling systems have been shown in previous studies (Thunell et al., 1983; Thunell and Reynolds, 1984; Sautter and Thunell, 1991; Curry et al., 1992) to exert a strong influence on the production of planktonic foraminifera. Upwelling events induced by mesoscale variability commonly occur in regions of the North Atlantic where major currents and oceanic fronts are present (Krauss et al., 1990a). The synoptic view afforded by satellite imagery has proven to be a powerful tool for the remote sensing of these mesoscale flow fields (Viehoff and Fischer, 1988; Krauss et al., 1990a, 1990b) which can influence physical and biological processes in the water column. Surface temperature distributions derived from satellite data can be particularly useful for studying upwelling events in regions where hydrographic data are sparse or unavailable. Since Fairbanks et al. (1980) estimates that 50 to $75 \%$ of the foraminiferal flux in the northern Sargasso Sea originates within cold-core rings (eddies), determining the effects of mesoscale circulation fields on foraminiferal production is important for interpreting the sedimentary record in the North Atlantic. The temporal resolution of the flux data in this study is sufficient for recording the imprint of local mesoscale variability on the seasonal hydrographic cycle.

\section{BACKGROUND}

\section{Seasonality in Foraminiferal Production}

Bé and his associates (Bé and Tolderlund, 1971; Tolderlund and Bé, 1971; Bé, 1977) first utilized plankton tows to study the seasonal variability in abundance of foraminiferal species in regions of the North Atlantic. The seasonal succession of species assemblages observed in this early work reflects seasonal changes in the 


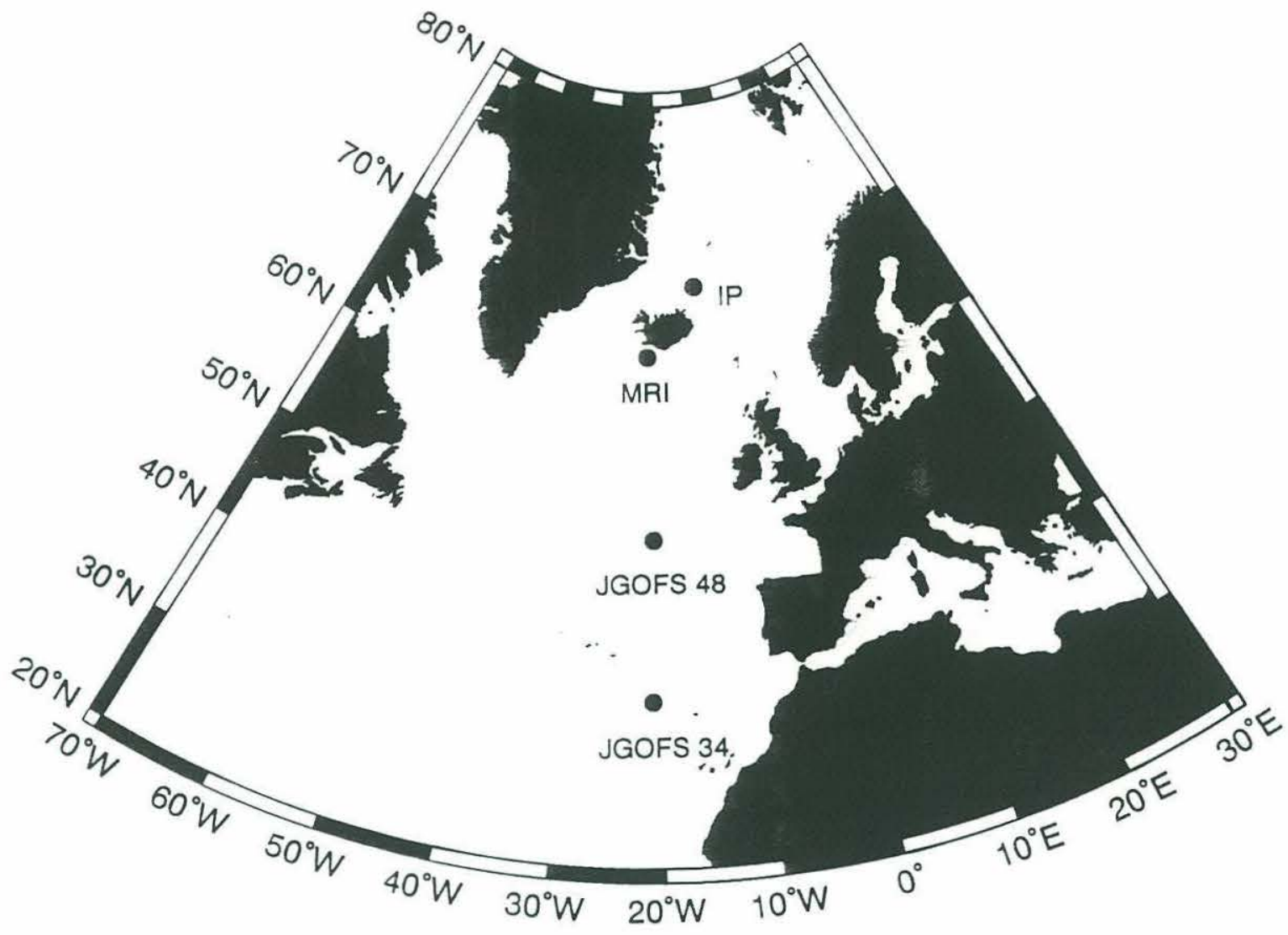

Figure 1. Map of North Atlantic showing locations of the four sediment trap moorings used in this study. 
thermal structure of the water column. The most important effects of hydrographic variability on foraminiferal production appear to be its control on thermocline depth and the transfer of nutrients into the euphotic zone (Hemleben et al., 1989). The global distribution patterns of many individual species in surface waters (Bé and Tolderlund, 1971; Hemleben et al., 1989) and in surface sediments (Bé, 1977) appear as distinct latitudinal belts, implying that species also live within tolerance ranges of seawater temperatures. Measured temperature ranges of planktonic foraminifera in laboratory cultures (Bijma et al., 1990) compare well with the limits observed in these biogeographical studies, suggesting that water temperature plays an important role in the biogeographical distribution of different species. Tolderlund and Bé (1971) investigated the western North Atlantic and found that the seasonal abundance of foraminiferal species is also dependent on the seasonal cycle in primary production. Planktonic foraminifera are dependent on phytoplankton either directly as a food source or indirectly through predation on herbiverous zooplankton (Bé et al., 1977; Spindler et al., 1984). The spring phytoplankton bloom in the North Atlantic occurs in response to the local seasonal development of the thermocline and is one important mechanism for increasing food availability in the euphotic zone. An abundant food source enhances the growth and reproductive capacity of individual foraminiferal species in surface waters of appropriate temperature for their survival (Hemleben et al., 1989).

The time-series capability afforded by sediment trap technology improves the temporal resolution for documenting seasonal variations in foraminiferal production and relating these changes to local hydrographic conditions. Automated time-series sediment traps (Honjo et al., 1980) allow the vertical flux of foraminiferal tests from surface waters to be collected in consecutive short-duration samples. Recent studies of foraminiferal production using automated sediment trap data have been conducted in various regions of the world including the Panama Basin (Thunell et al., 1983; Thunell and Reynolds, 1984), the northeast Pacific (Reynolds and Thunell, 1985; Thunell and Honjo, 1987; Sautter and Thunell, 1989), the San Pedro Basin (Sautter and Thunell, 1991; Thunell and Sautter, 1992), and the Arabian Sea (Curry et al., 1992). These 
flux data confirm the close coupling between the abundance of foraminiferal tests collected by the traps and the primary productivity of overlying surface waters. Laboratory culture experiments on planktonic foraminifera support the field data by showing a positive correlation of the growth rate and size of foraminiferal tests with feeding frequency (Anderson et al., 1979; Hemleben et al., 1989). Sediment trap studies in the Panama Basin (Thunell and Reynolds, 1984) and in the San Pedro Basin (Sautter and Thunell, 1991) show that sharp increases in foraminiferal flux occur in response to periods of intense seasonal upwelling. Upwelling resulted in a shoaling of the thermocline and the advection of nutrient-rich deep water towards the surface which triggered increased phytoplankton production. Similar hydrographic changes occur in the North Atlantic within cyclonic cold-core eddies generated by meanders of major current systems.

\section{Mesoscale Variability}

Branches of the North Atlantic Current are major sources of mesoscale eddy production which exert an important influence on the biological productivity in surface waters of the northeast Atlantic. Satellite-tracked drifting buoys and satellite (AVHRR) imagery used in previous studies (Krauss and Meincke, 1982; Krauss and Käse, 1984; Krauss, 1986; Viehoff and Fischer, 1986; Krauss et al., 1990b) have clarified pathways of the North Atlantic Current and shown the current field to be dominated by mesoscale eddies and meanders. Meanders are generated by the baroclinic instabilities within the frontal zones associated with this current system (Krauss et al., 1990a). Meandering currents can be readily recognized in temperature distributions by the congestion of isotherms along a wavelike course (Dietrich et al., 1980: Fig. 10.44, p. 533). Cyclonic cold-core eddies develop from meanders that intensify and grow into elongated loops that are eventually cut off from the main stream (Dietrich et al., 1980: Fig. 7.23, p. 327). The North Atlantic Current is the direct extension of the Gulf Stream and is associated with the Polar Front, considered the main source of eddy kinetic energy in the northern North Atlantic (Krauss and Käse, 1984). The southern branch of the Gulf Stream recirculation originates in an area southeast of 
Newfoundland and is known as the Azores Current. It is a relatively narrow current that continues eastward along $\sim 35^{\circ} \mathrm{N}$ (Krauss et al., 1990b) and is apparent in seawater temperature distributions as the Azores Front (Käse and Siedler, 1982; Käse et al., 1985; Gould, 1985). Considerable meandering of the Azores Current has been observed (Käse and Siedler, 1982; Gould, 1985), and the associated subtropical front appears to mark the northern limit of the $18^{\circ} \mathrm{C}$ water mass (Gould, 1985). Eddy kinetic energy increases in the eastern North Atlantic from the subtropical gyre toward the Polar Front at $\sim 50^{\circ} \mathrm{N}$ (Krauss and Böning, 1987). Krauss et al. (1990a) also found that satellite (AVHRR) images of higher latitudes in the North Atlantic more commonly reveal eddy structure at the sea surface because of larger horizontal temperature gradients.

\section{Deep Chlorophyll Maximum}

Fairbanks and Wiebe (1980) examined the vertical association of planktonic foraminifera and phytoplankton in the water column and found abundant populations of foraminifera at the chlorophyll maximum in the North Atlantic. The deep chlorophyll maximum (DCM) is a region rich in plant chlorophyll (phytoplankton) that generally coincides with the thermocline at the base of the mixed layer. The DCM develops seasonally in temperate latitudes $\left(>40^{\circ} \mathrm{N}\right)$ where it is usually found only in stratified water columns during the summer (Parsons et al., 1984). The DCM represents an important food source for deeper dwelling planktonic foraminifera (Fairbanks et al., 1982). Because foraminifera are dependent on food availability, the position of the DCM will strongly influence the depth habitats of certain species. Plankton tow studies and oxygen isotope analyses by Fairbanks and his colleagues (Fairbanks et al., 1980, 1982; Fairbanks and Wiebe, 1980) have shown that most species live in the euphotic zone at depths controlled largely by their temperature preference. Changes in the thermal structure of the photic zone that occur during cyclonic eddy circulation can alter the depth of the DCM and thus affect species distributions in the upper water column. A model proposed by Thunell and Honjo (1987) suggests that certain surface layer temperatures and food source associations are optimal for foraminiferal 
production and that maximum production should occur when food availability is high and the thermal structure is optimal for a specific species assemblage.

\section{METHODS}

\section{Sample Processing}

PARFLUX type time-series sediment traps (Honjo and Doherty, 1988) were deployed at four locations in the North Atlantic (Figure 1). Three sediment traps were deployed at each of the two southern stations $\left(34^{\circ} \mathrm{N} 21^{\circ} \mathrm{W}\right.$ and $\left.48^{\circ} \mathrm{N} 21^{\circ} \mathrm{W}\right)$ for one year from April 1989 to April 1990. This deployment was part of the JGOFS North Atlantic Bloom Experiment (NABE) (Ducklow, 1989). The JGOFS moorings (JGOFS 34 and JGOFS 48) each consisted of three automated sediment traps attached to a mooring line at water depths of approximately $1 \mathrm{~km}$ and $2 \mathrm{~km}$, as well as $0.7 \mathrm{~km}$ above the sea bottom. Each sediment trap was designed to collect and store a time series of thirteen consecutive two-week samples with the collection periods synchronized for all six traps. The traps were recovered and redeployed once, allowing a year of particle flux to be collected (Honjo and Manganini, 1993). A more detailed description of station parameters and procedures of trap deployment and sample recovery is contained in Honjo and Manganini $(1992,1993)$.

Sediment traps at the two northern stations were both single trap deployments that collected flux data for this study from October 1988 to October 1989. This deployment period provided an approximate six month time overlap with the two JGOFS stations to the south. The MRI (Marine Research Institute) trap was located off the southwest coast of Iceland on the shelf at $63^{\circ} \mathrm{N} 22^{\circ} \mathrm{W}$. The IP (Iceland Plateau) location is north of Iceland at $68^{\circ} \mathrm{N} 13^{\circ} \mathrm{W}$. The MRI and IP traps were positioned at water depths of 586 meters and 1470 meters, respectively. These mooring stations have been occupied continuously since 1986 . For this study, thirteen consecutive one month samples were collected by each trap. The timing of collection periods was five days earlier at the IP location.

The recovered samples were split into aliquots using a Erez-Honjo precision rotary splitter (Honjo, 1978), and one aliquot of each trap sample was used for faunal anal- 
ysis. All planktonic foraminifera larger than $150 \mu \mathrm{m}$ were picked, identified to the species level, and counted for each aliquot used in this analysis. Specimens smaller than $150 \mu \mathrm{m}$ were not tabulated for this study due to the predominance of juveniles and the difficulty in identifying some species in the smaller size fractions. Right and left coiling forms of Neogloboquadrina pachyderma were each counted as individual species because of their dependence on different thermal environments (Reynolds and Thunell, 1986). Globigerina falconensis was included in the counts for Globigerina bulloides. A clinal relationship exists between these two species (Bé and Tolderlund, 1971) which have very similar morphologies.

Raw specimen counts were converted to shell flux (\# (of tests) $\mathrm{m}^{-2} \mathrm{day}^{-1}$ ) for each individual species and for calculations of total flux. This conversion is based on the duration of the collection period, the cross-sectional area of the sediment trap, and the fractional size of the aliquot used for the sample. Flux data derived from these sediment traps represent averages over individual collection periods. Absolute and relative abundance (percent of total flux) of each foraminiferal species were calculated for each sampling period. Seasonal records of absolute abundance data allow the periods of preferred production to be determined for each planktonic species (Sautter and Thunell, 1991). Relative abundance is also particularly important in this study because it characterizes the changes in faunal composition at a particular location and is the best direct method of comparing species compositions of living populations with fossil assemblages in deep-sea cores.

\section{Time Correction Factors}

The timing of initial shell growth in planktonic foraminifera is important for understanding variations in foraminiferal production and how these changes relate to SST and near-surface hydrography. It is thus necessary to estimate the lag time that occurs between the specimen's initial production and its collection in the sediment trap. This time correction factor must account for both the life span of individuals in surface waters and the settling time of empty tests to trap depth. There is little direct data available that quantifies the life spans of planktonic foraminifera. It is 
known that some species exhibit a lunar or semi-lunar reproductive cycle (Hemleben et al., 1989) which implies a life span of about two to four weeks. Berger and Soutar (1967) estimated an average life span of about one month for four species in the California Current while Berger (1971) suggested that life spans of most planktonic foraminifera in fertile regions were no more than two weeks. The laboratory work of Anderson et al. (1979) and Bé et al. (1981) also suggests that life cycles may be shortened by increased feeding frequency during periods of high fertility (e.g. upwelling) because of rapid growth and early reproductive maturity. Individuals of Globigerinoides sacculifer (a surface-dwelling species) living in laboratory culture under high light intensity with different feeding regimes had mean survival times ranging from 10 days (fed daily) to 31 days (starved) (Bé et al., 1981). On the basis of these previous laboratory and field studies, a conservative life span of three weeks was assumed for this study. Settling speeds were derived from the laboratory data of Takahashi and Bé (1984). An average settling velocity of 350 meters day ${ }^{-1}$ was determined for this study from their estimation of sinking speeds for the "A-group" of planktonic foraminifera. Based on average life span and settling velocity, time correction factors were calculated for the JGOFS middle traps (27 days), the JGOFS 48 deep trap (32 days), the MRI trap (23 days), and the IP trap (25 days). Increases in shell flux recorded in this study thus reflect increases in foraminiferal production occurring about one month prior to collection in the sediment trap. An approximate one month time correction compares well with the isotopic data of Deuser (1986) who found a one month lag between the formation of Globigerinoides ruber tests near the surface and their entrapment at $3200 \mathrm{~m}$ in a trap in the Sargasso Sea.

\section{Satellite (AVHRR) Data}

Satellite-derived multi-channel sea surface temperature (MCSST) data for each sediment trap location during the years 1988-1990 were acquired through the Distributed Active Archive Center at NASA Jet Propulsion Laboratory (Smith, 1992). The database consists of weekly SST composites for the North Atlantic region at approximately $18 \mathrm{~km}$ horizontal pixel resolution. Data were collected by the advanced 
very high resolution radiometer (AVHRR) on board TIROS-N/NOAA series polar orbiting satellites (Smith, 1992). The AVHRR instrument is a multi-channel scanning radiometer that provides sea surface temperatures by passively measuring emitted radiation in visible, near infra-red, and infra-red spectral channels (Bernstein, 1984). The algorithms used to compute the MCSST are described by McClain et al. (1985). Each MCSST value in a weekly composite is the result of block averaging all cloudfree pixels over seven days within an approximate $8 \mathrm{~km} \mathrm{x} 8 \mathrm{~km}$ area around a center grid point. Sea surface temperatures in all open areas (i.e. no cloud-free observations) are interpolated. A separate weekly "mask" data set contains the number of true observations used to calculate the temperature value at each grid point location. The "mask" data for the SST distributions presented in this study are included in Appendix II. SST data at the closest gridpoint to each trap station were used to construct seasonal SST records.

Shipboard-measured CTD data were compared with synchronous MCSST data to determine the degree of accuracy of the satellite measurements (Figure 2). MCSST data within the Transitional and Subtropical zones of the North Atlantic at values greater than $11^{\circ} \mathrm{C}$ exhibit a high degree of accuracy when compared with in situ data. High latitude satellite data in the vicinity of the MRI and IP stations, however, show significant error relative to the CTD data. This error is probably the result of seasonal cloud cover. There was a significant reduction in the number of high latitude MCSST observations due to persistent cloud cover between October and February of each year. High latitude SST data for this study, particularly at the IP location, contain significant error during these months. Fortunately, the flux of foraminifera during the winter at high latitudes is so low that the effects of this error on our data are minimal. NOAA also continuously monitors the quality of the MCSST data with satellite-tracked drifting buoys that measure SST within $25 \mathrm{~km}$ and 4 hours of a pixel location (Halpern et al., 1992). During 1989 there was an average of 384 matchups per month throughout the global ocean with the MCSST averaging only $0.02^{\circ} \mathrm{C}$ higher than the in situ data with a rms (root mean square) difference of $0.72^{\circ} \mathrm{C}$ (Halpern et al., 1992). 


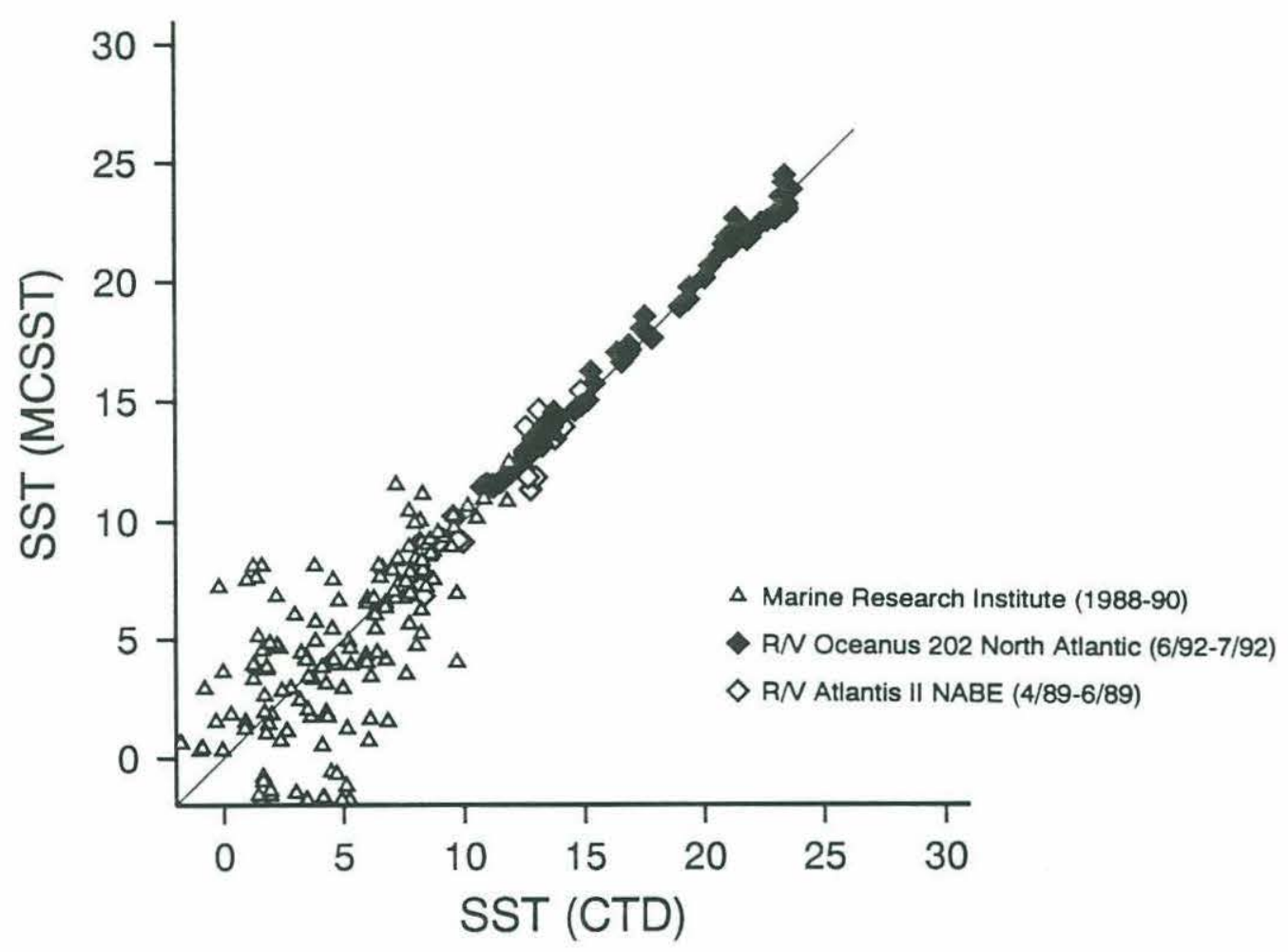

Figure 2. Comparison of in situ SST data from CTD profiles with concurrent satellite-derived MCSST data in the North Atlantic. The solid line indicates matching results. There is a poor correspondence of temperature data below $\sim 11^{\circ} \mathrm{C}$ because of seasonal cloud cover at high latitudes that significantly reduces the number of true MCSST observations. 


\section{RESULTS}

\section{JGOFS Stations}

Total foraminiferal fluxes $(>150 \mu \mathrm{m})$ and SST data for the trap deployments at JGOFS 34 and 48 are presented in Figures 3 and 4 . The horizontal time axis used for all presentations of temperature and flux data is given in cumulative Julian days (JD) with day number one being January 1, 1988. The appropriate time correction factor has been applied to all flux data presented for the four trap stations in this study. Uncorrected flux data from all trap deployments are tabulated in Appendix I. Flux data from the middle trap of the array are shown for the two JGOFS locations with the exception of the last ten collection periods for JGOFS 48. A malfunction in the middle trap prevented sample collection during this interval (Honjo and Manganini, 1993), so results from the deep trap have been substituted. The surface temperature record at JGOFS 34 shows a typical unimodal distribution ranging from a low of about $16^{\circ} \mathrm{C}$ in March to a high of $26^{\circ} \mathrm{C}$ in August (Figure 3a). The SST range at JGOFS 48 is between 11.5 and $20.5^{\circ} \mathrm{C}$ (Figure $4 \mathrm{a}$ ) and shows a similar seasonal pattern. Periods of high foraminiferal flux associated with the annual spring bloom were recorded at both stations. The period of maximum flux $\left(2000 \mathrm{~m}^{-2} \mathrm{day}^{-1}\right)$ at JGOFS 34 occurs as a strong single peak during March and April (Figure $3 \mathrm{~b}$ ) at an SST of $\sim 18^{\circ} \mathrm{C}$. A period of high total flux, peaking at over $5000 \mathrm{~m}^{-2} \mathrm{day}^{-1}$, occurs later at JGOFS 48 during April and May (Figure 4b). Total flux is also increasing sharply at the end of trap deployment at JGOFS 48, probably signifying the beginning of the next spring bloom cycle. Flux increases after JD 700 at JGOFS 34 (Figure 3b) suggest a late fallwinter bloom at this location, but there is no evidence for a similar seasonal bloom at JGOFS 48.

Total flux records of the abundant foraminiferal species collected during the JGOFS trap deployments are presented in Figures 5 and 6 . The periods of high shell flux for individual species reflect preferred periods of production in surface waters. All species shown here exhibit sharp flux increases during the spring bloom period and reach highest production rates at that time. The relative abundances of species that 
individually account for more than $40 \%$ of the total foraminiferal flux during any JGOFS collection period are shown in Figures 7 and 8 to illustrate the seasonal succession of dominant species. Relative abundances are only included in this study for those sediment trap samples with a total flux of greater than $10 \mathrm{~m}^{-2} \mathrm{day}^{-1}$ for the sampling period. This minimizes the statistical inaccuracy of computing percentages for species when only a few individual specimens were actually counted.

G. ruber and $G$. bulloides are the most abundant species of planktonic foraminifera collected at JGOFS 34 (Figure 5). G. bulloides is clearly dominant during the colder winter months and early spring (Figure 7). G. ruber is the most prolific species during the rest of the year and constitutes nearly $100 \%$ of the assemblage during the warmest interval of the summer (Figure 7). Globigerinita glutinata, Globorotalia scitula, and Globorotalia inflata are present at JGOFS 34 (Figure 5c-e) but usually in low relative concentrations that decrease to near zero during the summer months.

G. bulloides and $N$. pachyderma (right coiling) are the most abundant species at JGOFS 48 (Figure 6). G. ruber, an abundant species at JGOFS 34, is nearly absent at this station. G. bulloides is the most dominant species during the spring bloom period (Figure $8 \mathrm{~b}$ ) but does not exhibit any significant periods of production later in the year (Figure 6a). N. pachyderma is also abundant during the spring and continues to be an important population during the summer months (Figure 6b). This species exhibits a secondary peak in production during the late summer that is not associated with any appreciable flux increases of other species. G. inflata, G. glutinata, and G. scitula each have periods of high relative abundance (Figure 8c-e), but these maxima are not associated with any significant increases in their production (Figure 6c-e). However, a pattern of seasonal succession of these species is evident at JGOFS 48 as surface waters cool during the fall and winter. G. bulloides is clearly the dominant species in the early fall, but the dominance shifts in a succession to $G$. inflata, followed by G. glutinata and G. scitula during the winter (Figure 8). 
(a) JGOFS 34 - Sea Surface Temperature

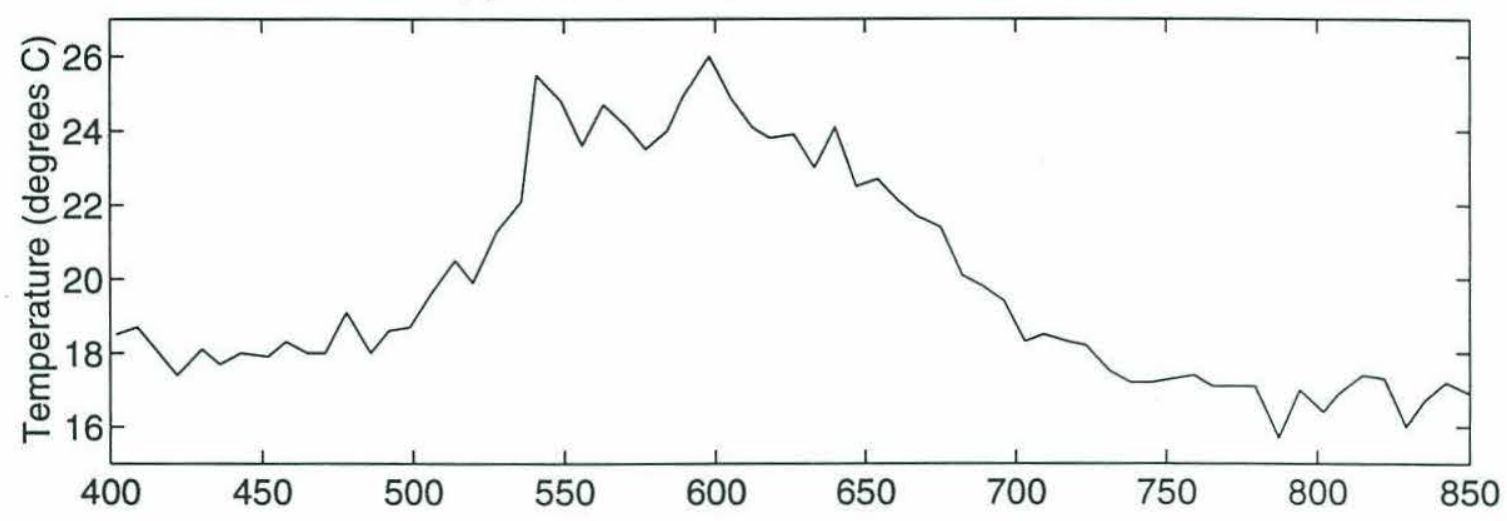

(b) JGOFS 34 - Total Flux

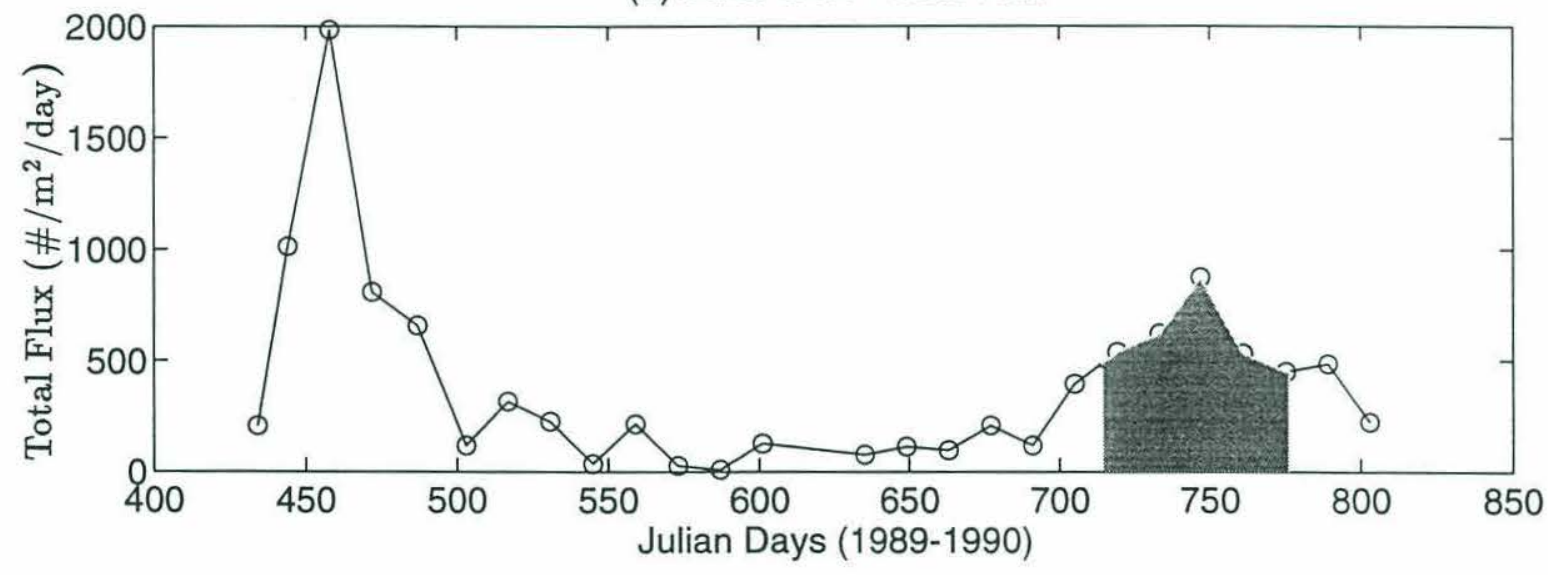

Figure 3. Annual variations in (a) sea surface temperature (SST) and (b) total foraminiferal flux for the JGOFS 34 sediment trap location. The shaded area in (b) represents the interval (JD 714-776) of high mesoscale variability shown in Figure 18 which coincides with a period of high foraminiferal flux at this trap site. 
(a) JGOFS 48 - Sea Surface Temperature

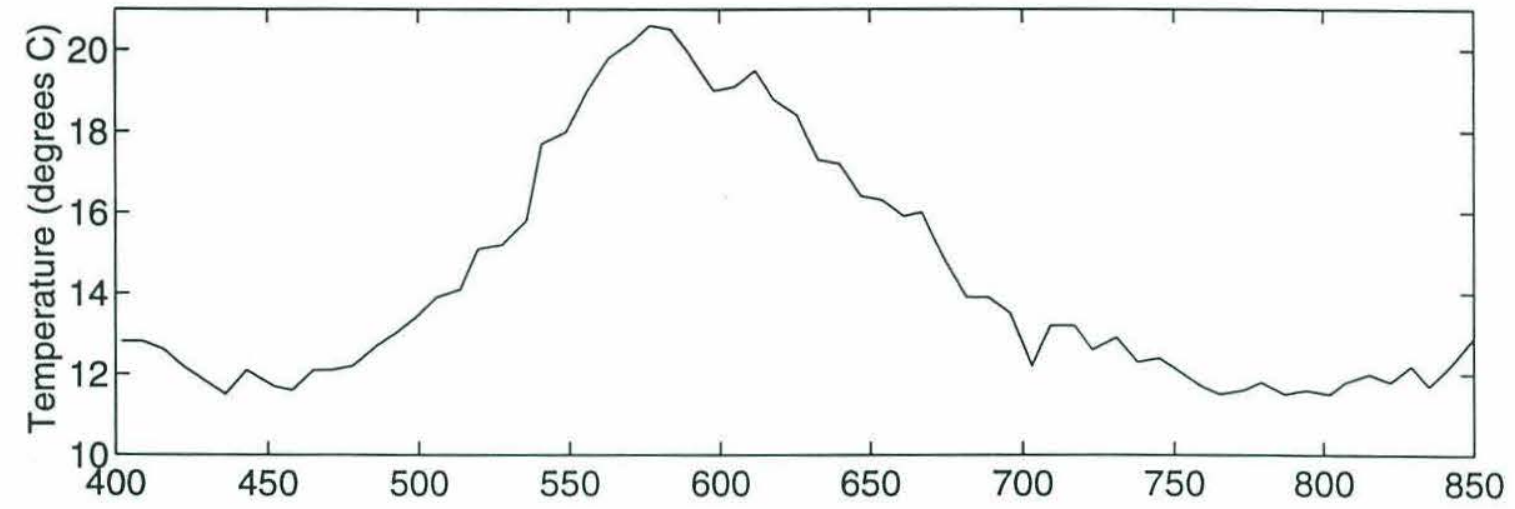

(b) JGOFS 48 - Total Flux

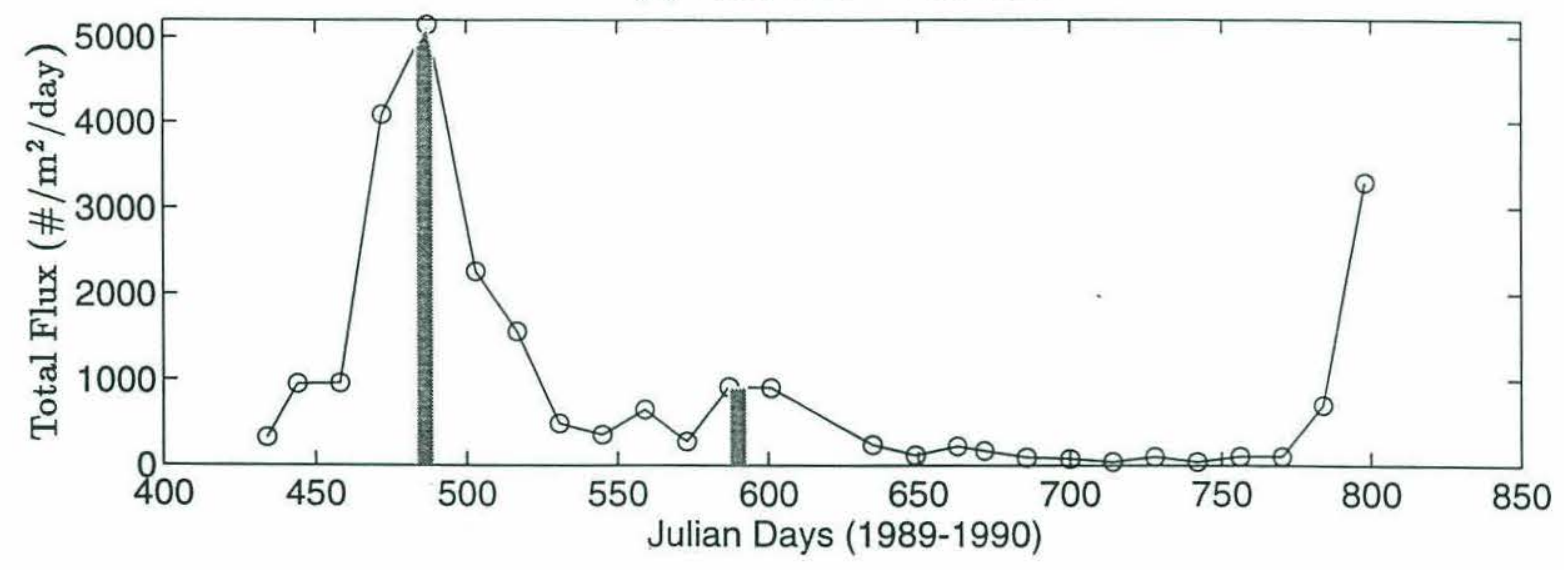

Figure 4. Annual variations in (a) SST and (b) total foraminiferal flux for the JGOFS 48 SST sediment trap location. The shaded areas in (b) represent the intervals of local mesoscale eddy production shown in Figures 16 (JD 483-489) and 17 (JD 587-593) which coincide with peaks in foraminiferal production at this trap site. 
Figure 5. Seasonal shell flux records of the most abundant foraminiferal species collected at JGOFS 34. The time-adjusted peaks in absolute abundance represent periods of preferred production for individual species. Note the different vertical scales. 
(a) JGOFS 34 - G. builoides

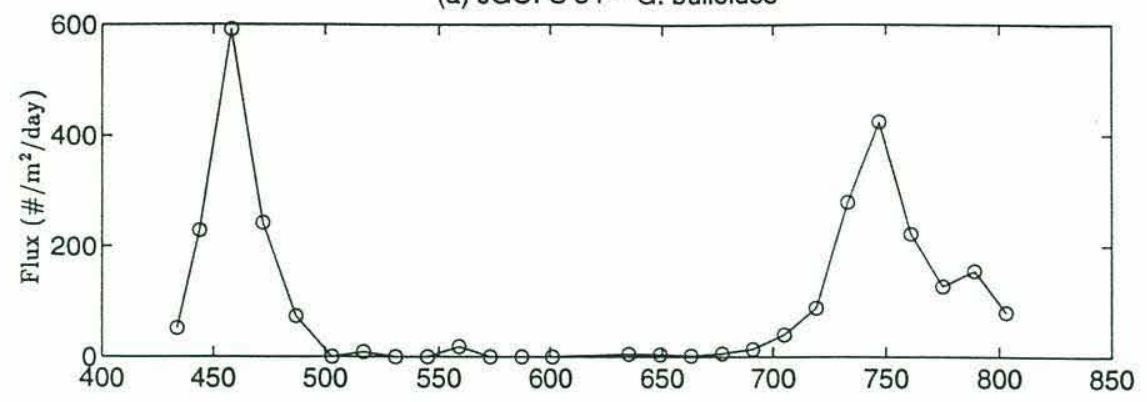

(b) JGOFS 34 - G. ruber

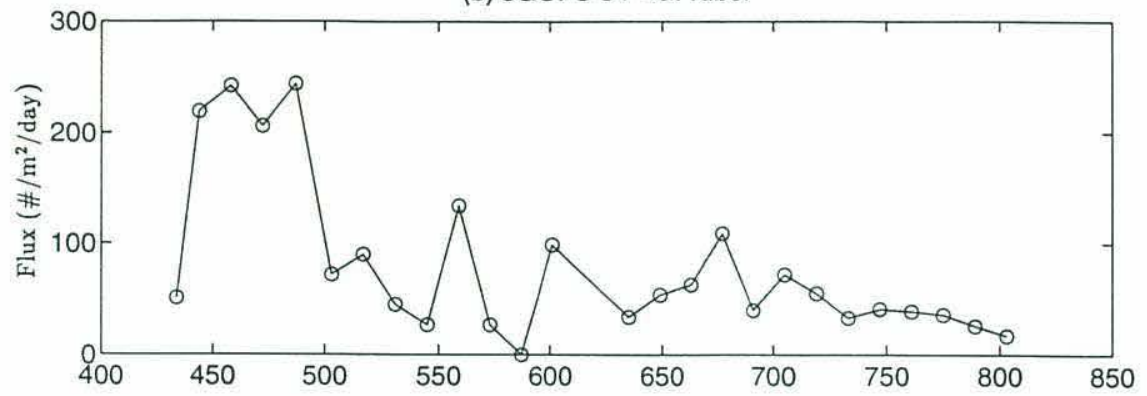

(c) JGOFS 34 - G. glutinata

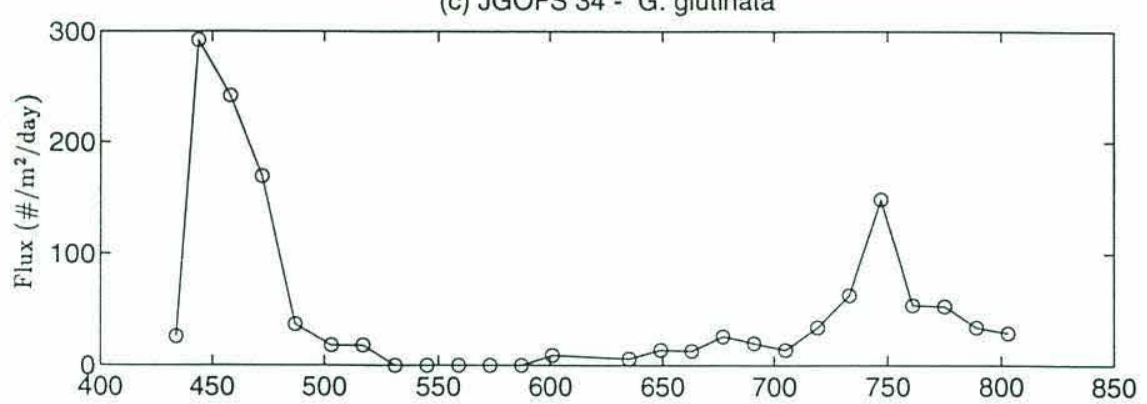

(d) JGOFS 34 - G. scitula

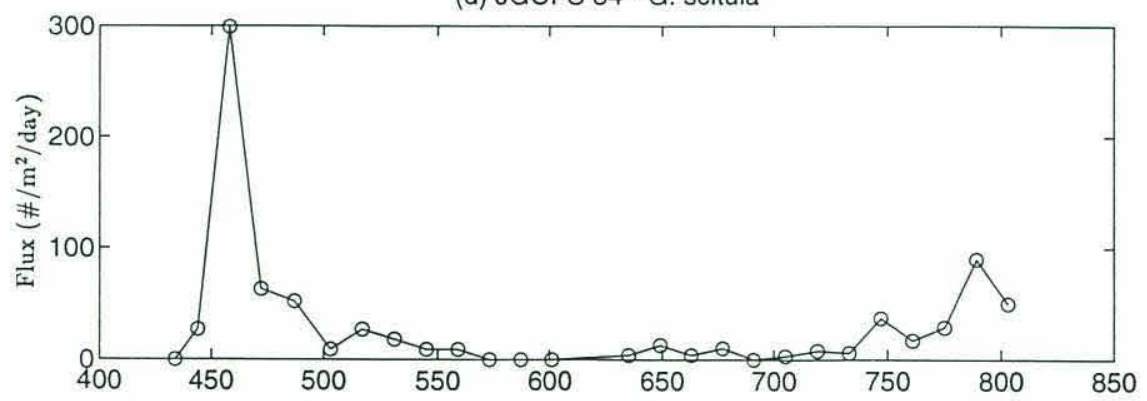

(e) JGOFS 34 - G. inflata

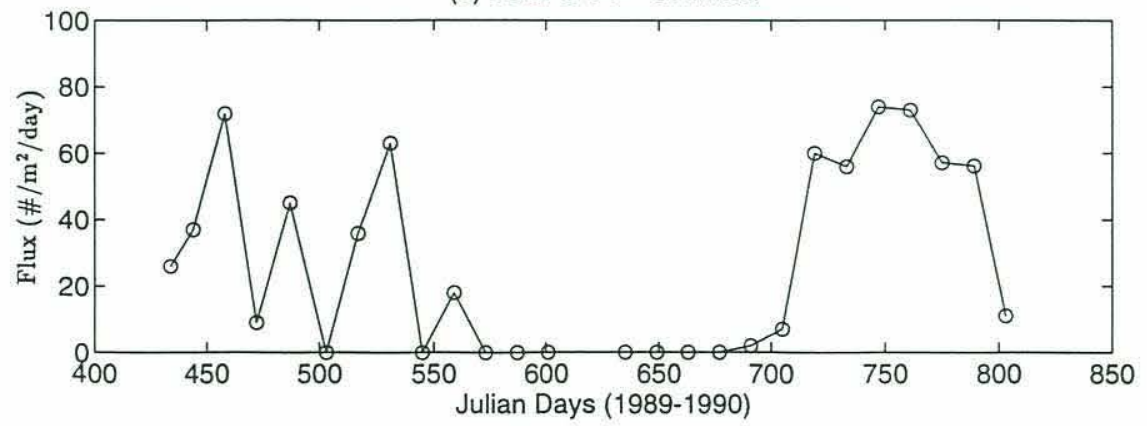


Figure 6. Seasonal shell flux records of the most abundant foraminiferal species collected at JGOFS 48. The time-adjusted peaks in absolute abundance represent periods of preferred production for individual species. The shaded area in (b) represents the interval (JD 587-593) of high mesoscale activity shown in Figure 17 that coincides with a seasonal peak in production of $N$. pachyderma (right coiling) at this location. Note the different vertical scales. 
(a) JGOFS 48 - G. bulloides

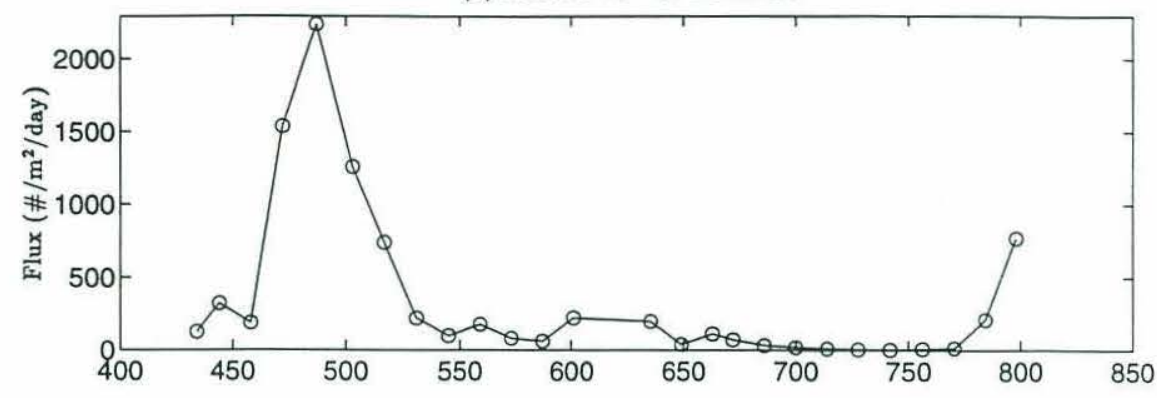

(b) JGOFS 48 - N. pachyderma (right)

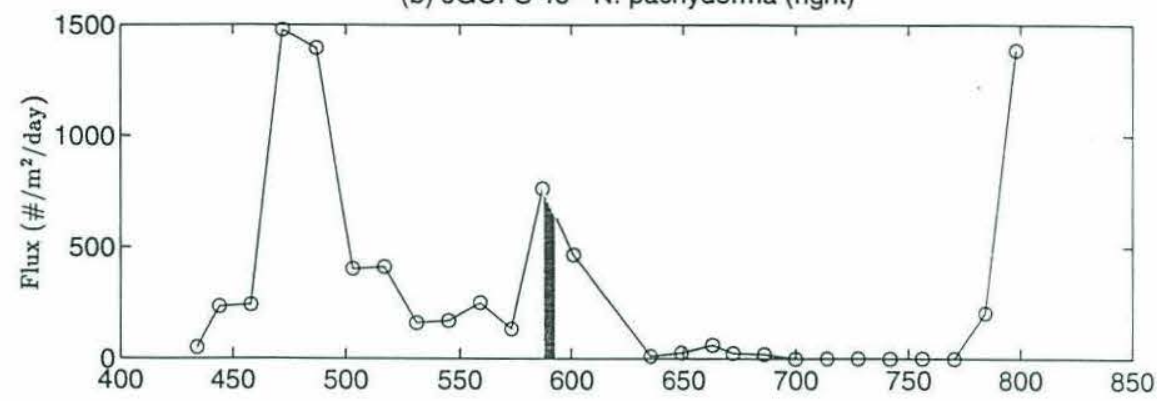

(c) JGOFS 48 - G. glutinata

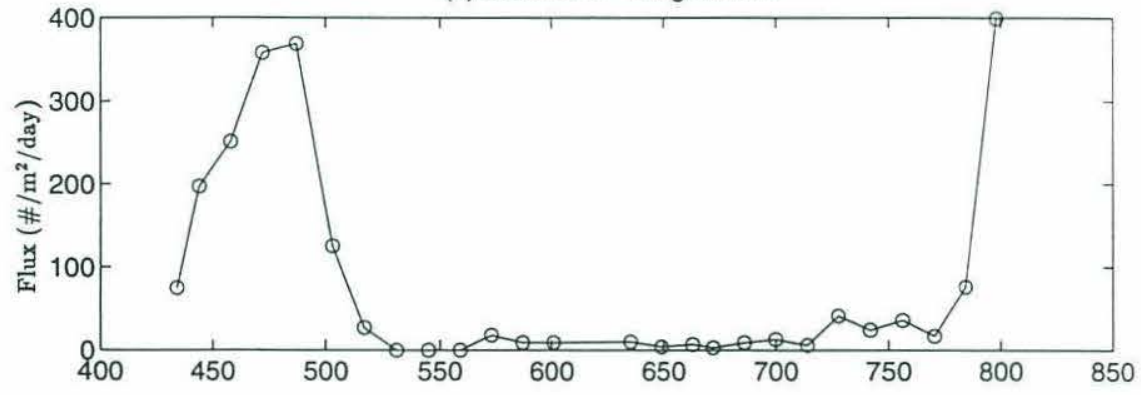

(d) JGOFS 48 - G. inflata

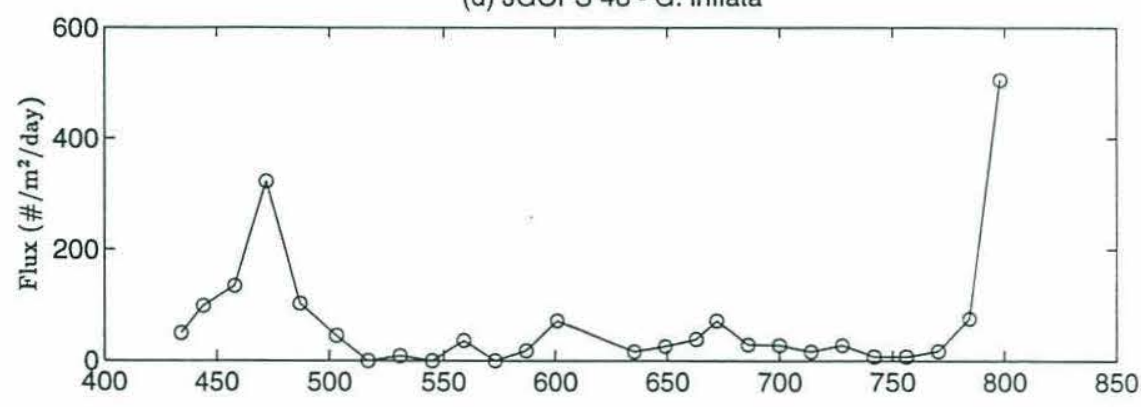

(e) JGOFS 48 - G. scitula

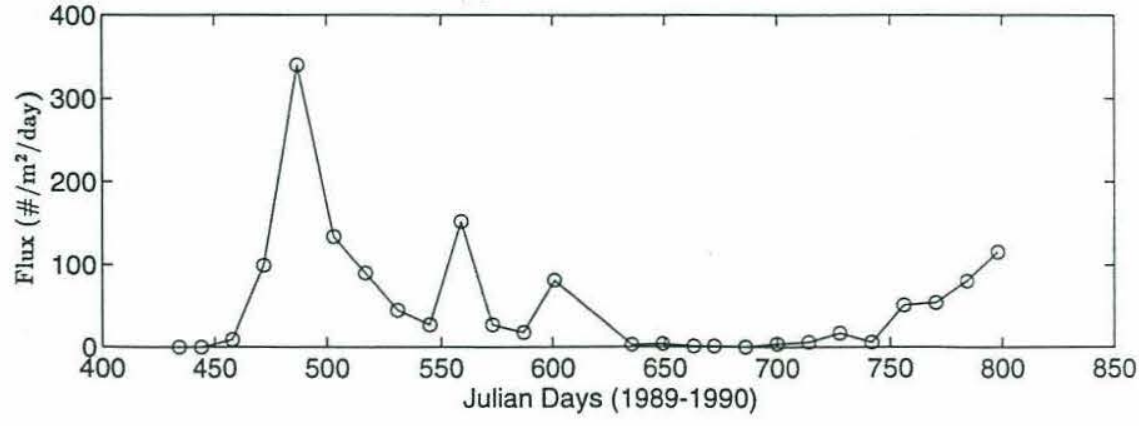




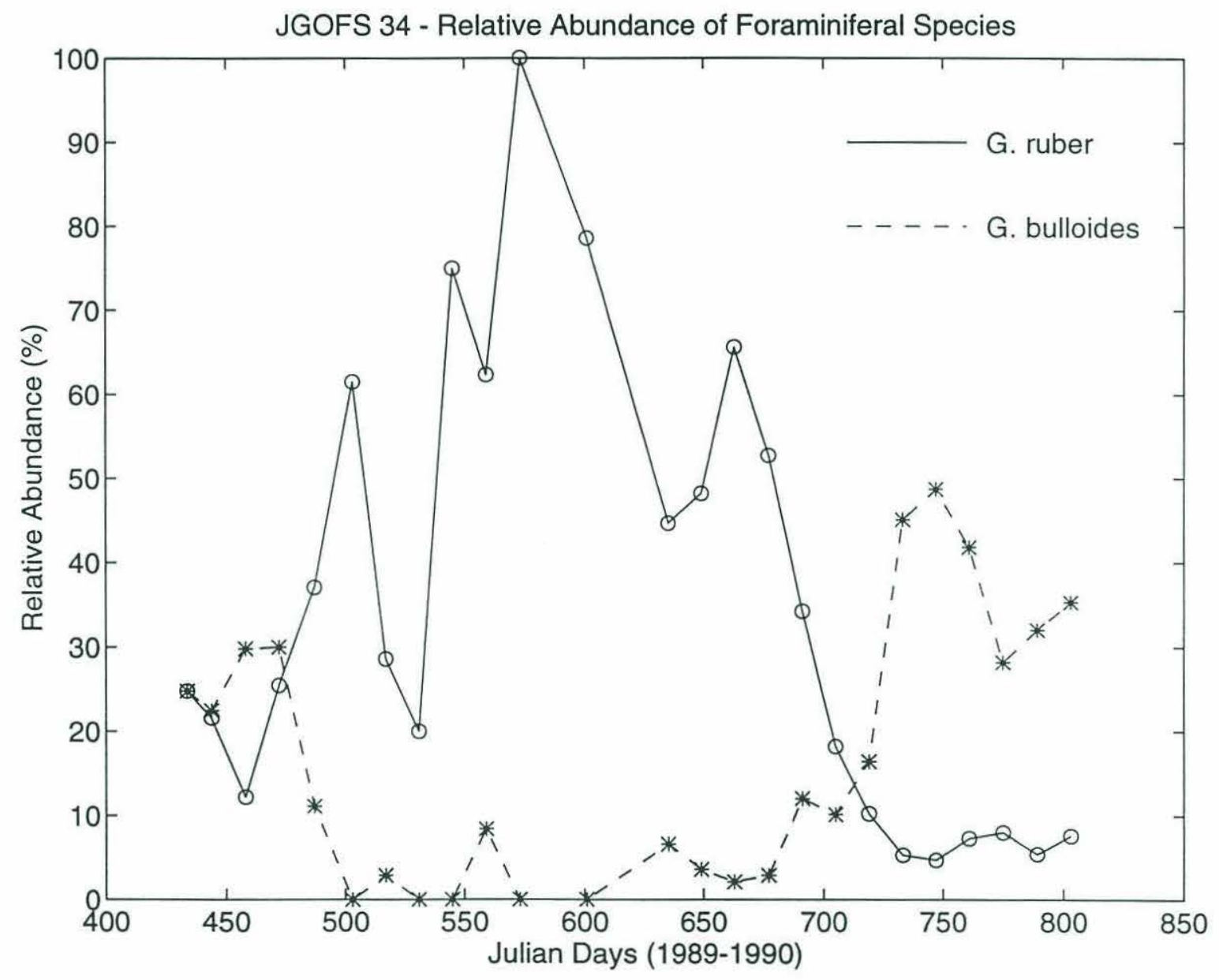

Figure 7. Relative abundances (\% of total flux) of the two most dominant species at JGOFS 34 . Note the distinct seasonal shift in species dominance between $G$. bulloides (winter-early spring) and G. ruber (spring-fall). 


\section{High Latitude Stations}

Foraminiferal flux data $(>150 \mu \mathrm{m})$ and SST records for the high latitude stations (MRI and IP) are shown in Figures 9 and 10. The low diversity of species collected at these two stations allows a more succinct presentation of the data compared with the JGOFS results. The temperature record at the MRI station is more erratic than the records at the JGOFS locations to the south, but it does exhibit a similar seasonal pattern (Figure 9a). The SST ranges from a low in March of about $6^{\circ} \mathrm{C}$ to a high in late August of $11^{\circ} \mathrm{C}$. The total flux collected here is the lowest of any of the four stations (Figure 9b). Foraminiferal flux remains at or near zero for most of the collection period before starting to increase in May. Maximum flux of 127 $\mathrm{m}^{-2} \mathrm{day}^{-1}$ occurs during the month of June, and values remain close to that level for the remainder of the summer. Globigerina quinqueloba is the single dominant species during the five collection periods from May to September, averaging over $60 \%$ of the total flux (Figure 9d). G. bulloides and N. pachyderma (right) are also present at MRI but in much lower concentrations, each averaging less than $15 \%$ of the total assemblage.

The SST at the IP station reflects its location above the Arctic Circle (Figure 10a). Temperature ranges from winter lows consistently below $0^{\circ} \mathrm{C}$ to a high of over $7^{\circ} \mathrm{C}$ in late summer. The anomalous and artificial increase in SST between JD 400 and JD 425 is due to the effects of seasonal cloud cover on satellite data retrieval during the winter months. Foraminiferal flux remains minimal most of the year but starts to increase slowly with the onset of summer (Figure 10b). This slow increase culminates with a large increase in foraminiferal production $\left(>2300 \mathrm{~m}^{-2}\right.$ day $\left.^{-1}\right)$ in late August. The foraminiferal assemblage collected during the summer is composed almost entirely of $N$. pachyderma (left coiling) (Figure 10d). There is evidence that G. quinqueloba is present in higher relative concentrations during the fall, but this is based on only two samples collected during periods of low flux. 
Figure 8. Relative abundances (\% of total flux) of foraminiferal species that account for more than $40 \%$ of the total shell flux during any collection period at JGOFS 48 . The SST record for JGOFS 48 is included in (a) for comparison with these data. The records are arranged according to the temporal position of dominance. These data illustrate the distinct seasonal succession of dominant species that occurs during the cooling of surface waters in the fall and winter at this location. 
(a) JGOFS 48 - N. pachyderma (right)

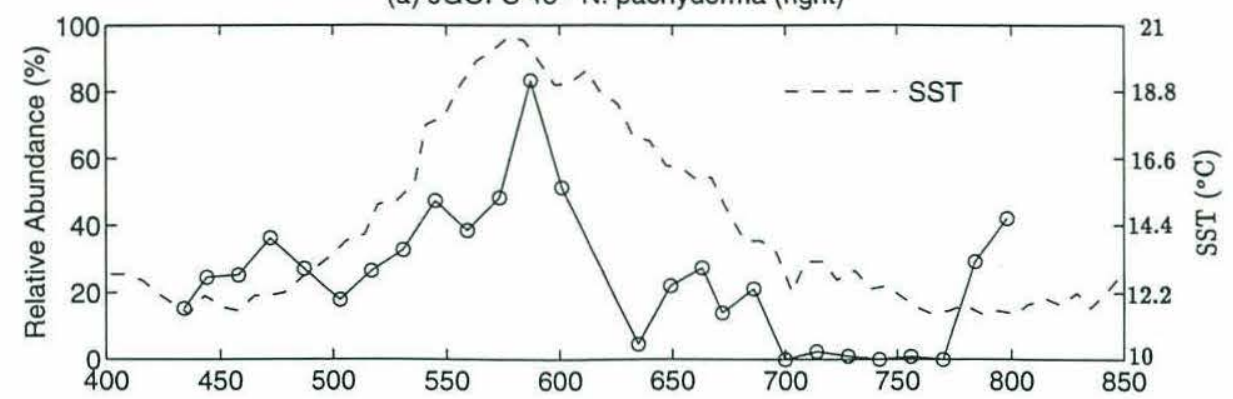

(b) JGOFS 48 - G. bulloides

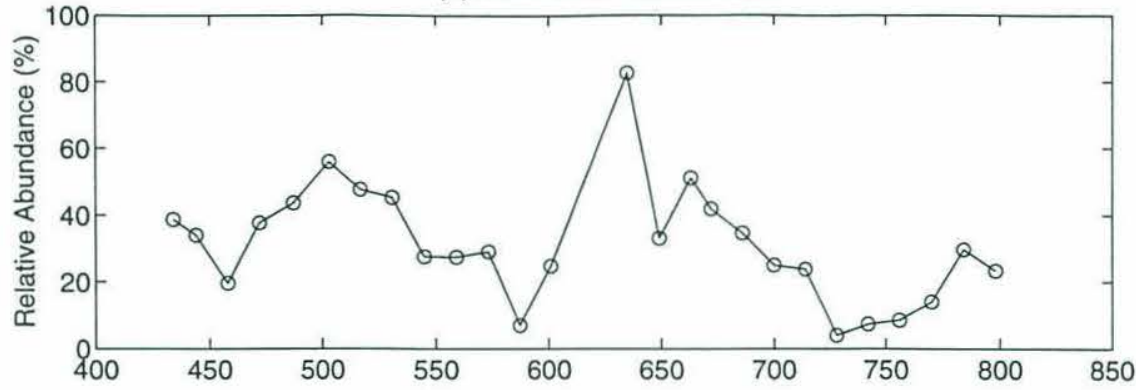

(c) JGOFS 48 - G. inflata

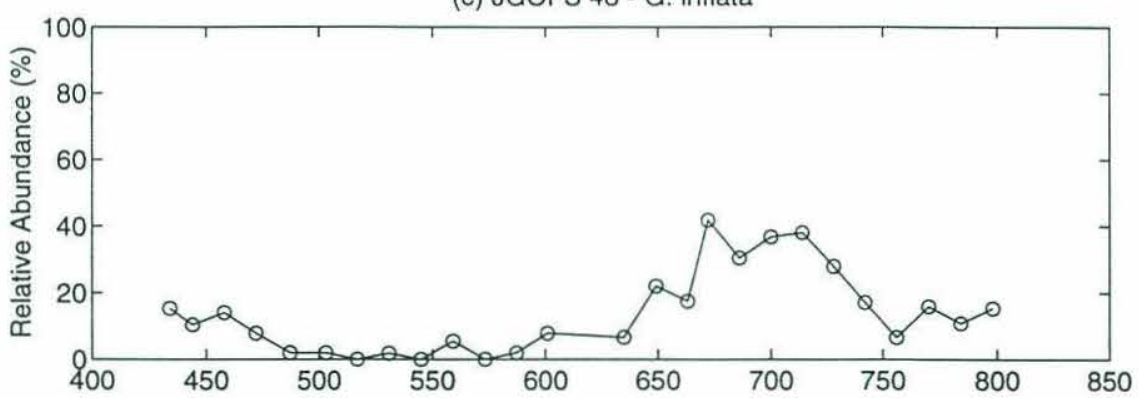

(d) JGOFS 48 - G. glutinata

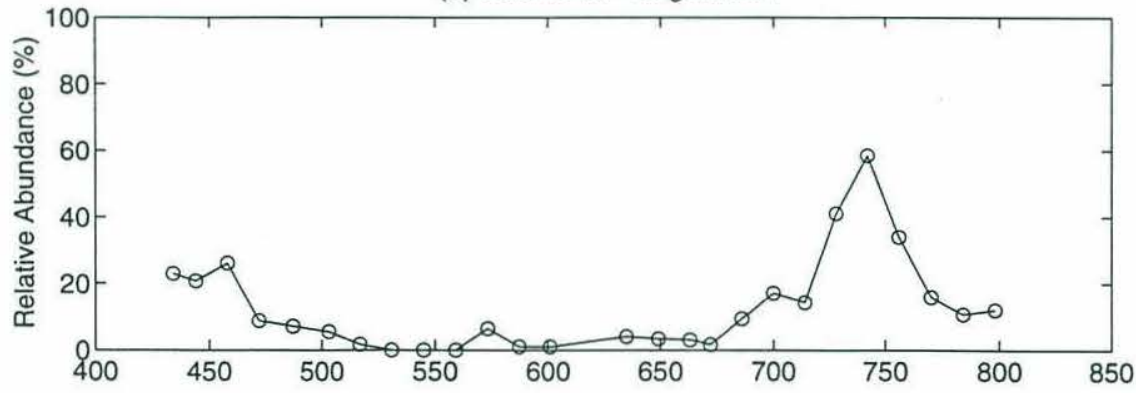

(e) JGOFS 48 - G. scitula

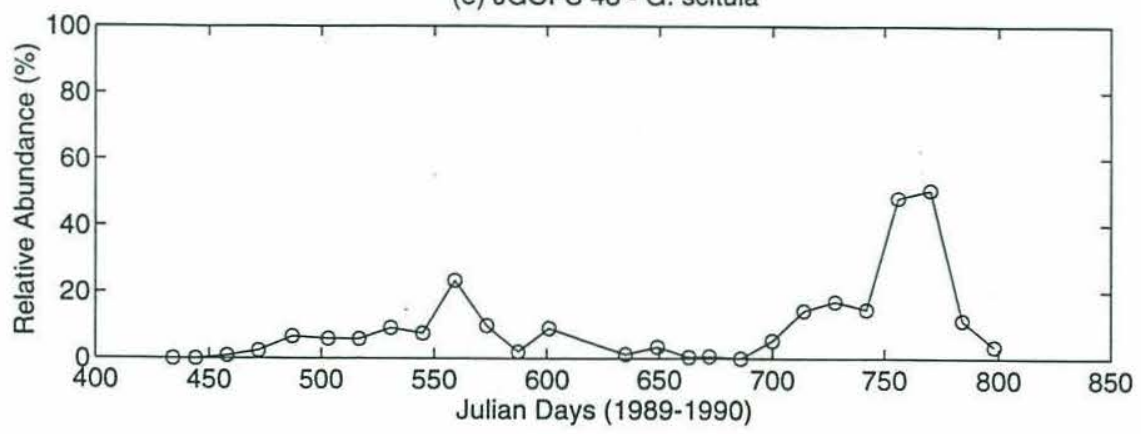


Figure 9. Satellite-derived SST and foraminiferal flux data for the MRI sediment trap location. "Low Total Flux" in (d) indicates that relative abundances were not calculated for samples within this interval because the total flux was less than $10 \mathrm{~m}^{-2}$ day $^{-1}$. 
(a) MRI - Sea Surface Temperature

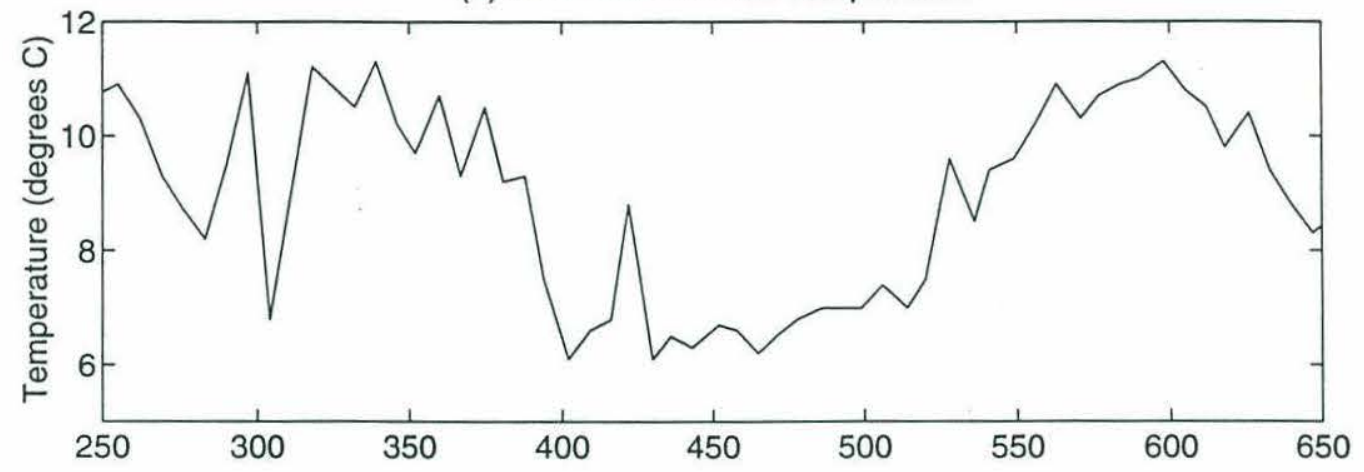

(b) MRI - Total Flux

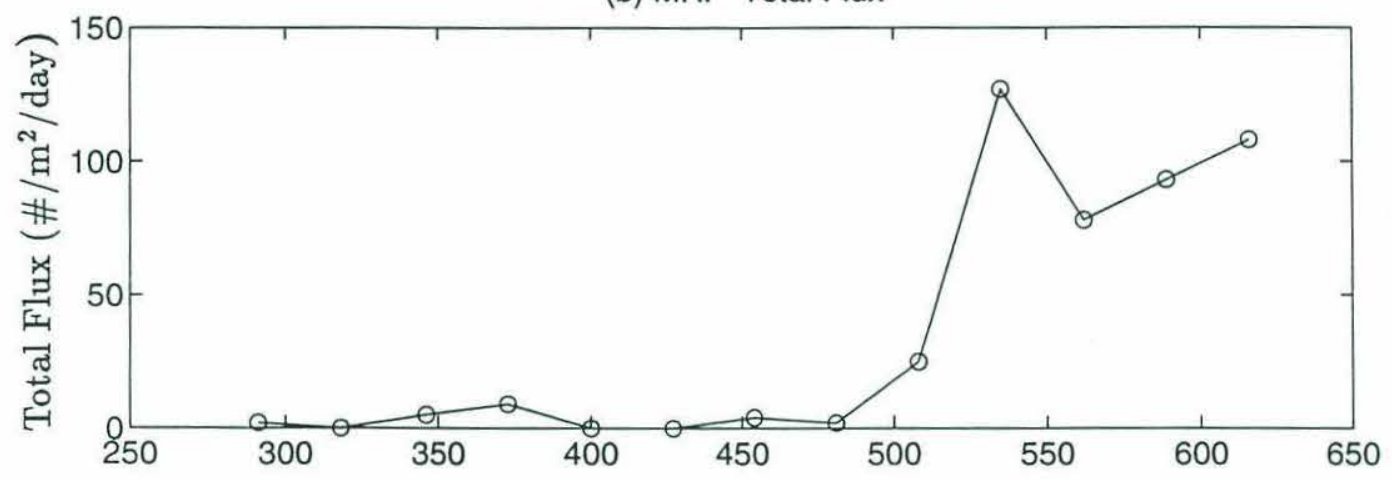

(c) MRI - Absolute Abundance of Foraminiferal Species

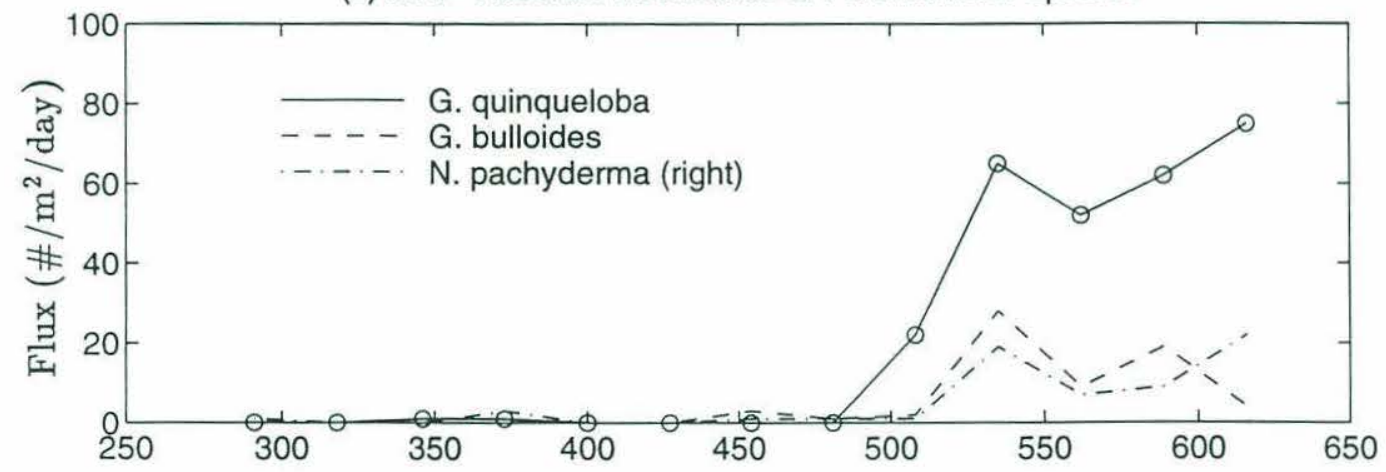

(d) MRI - Relative Abundance of Foraminiferal Species

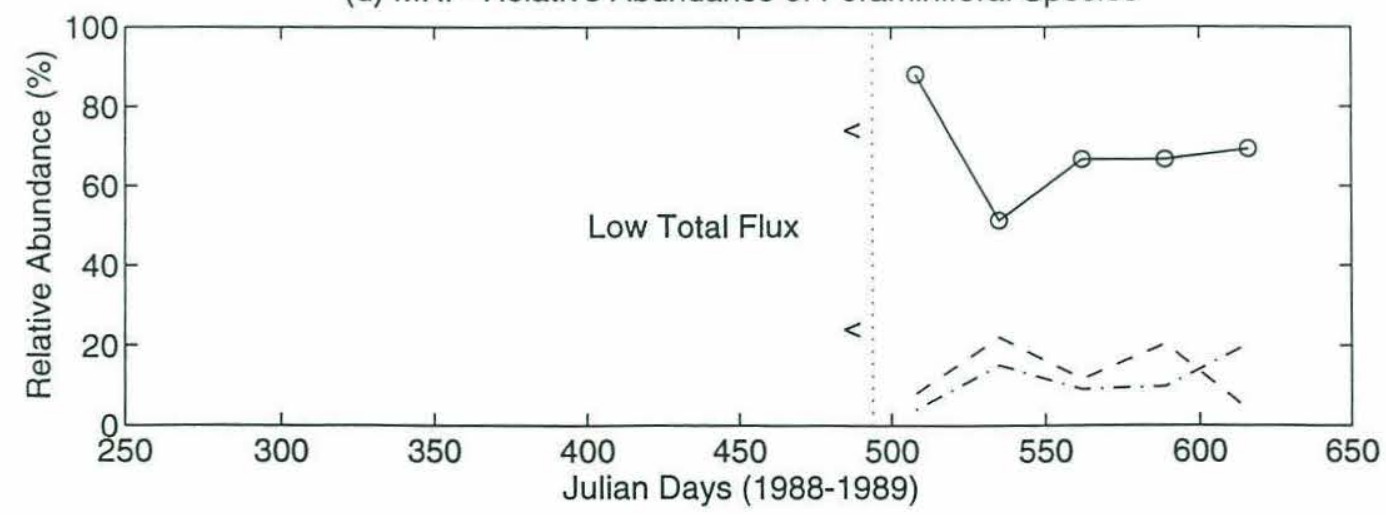


Figure 10. Satellite-derived SST and foraminiferal flux data for the IP sediment trap location. "Low Total Flux" in (d) indicates that relative abundances were not calculated for samples within this interval because the total flux was less than $10 \mathrm{~m}^{-2}$ day $^{-1}$. 
(a) IP - Sea Surface Temperature

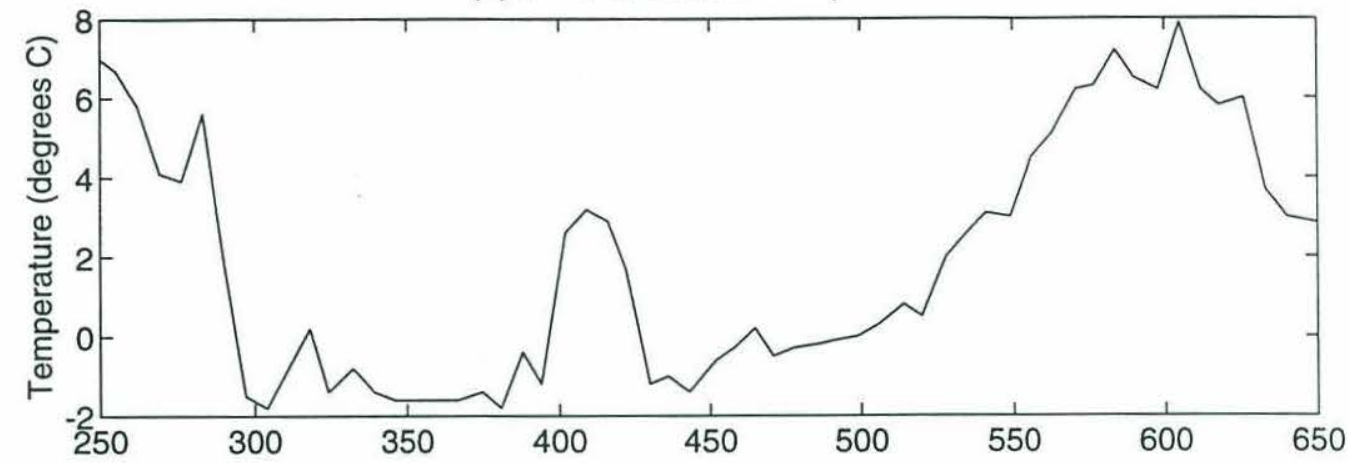

(b) IP - Total Flux

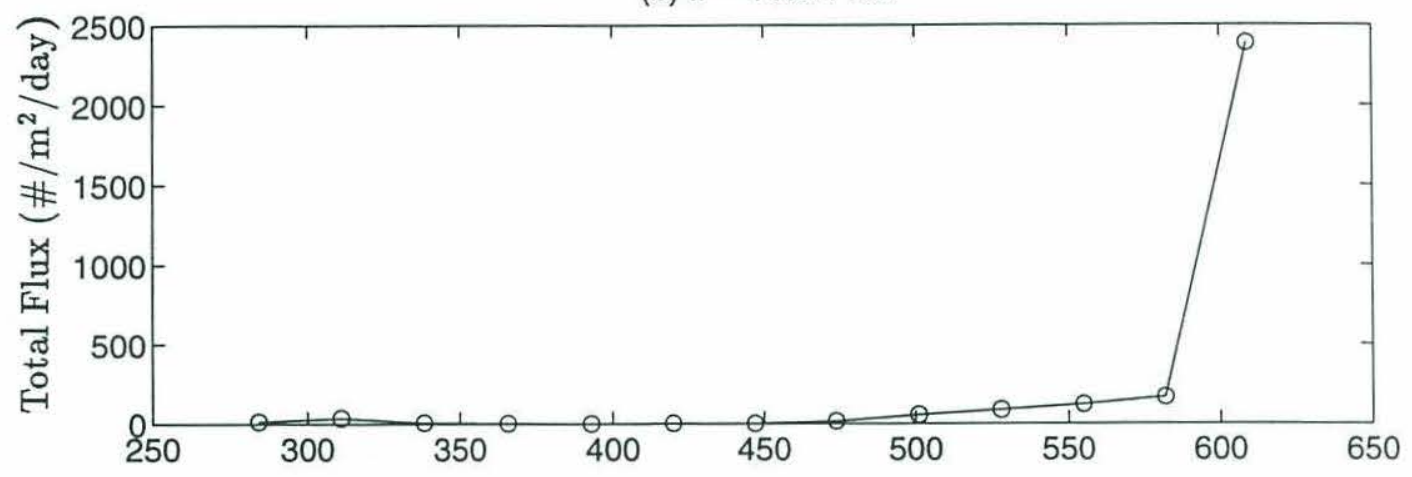

(c) IP - Absolute Abundance of N. pachyderma (left)

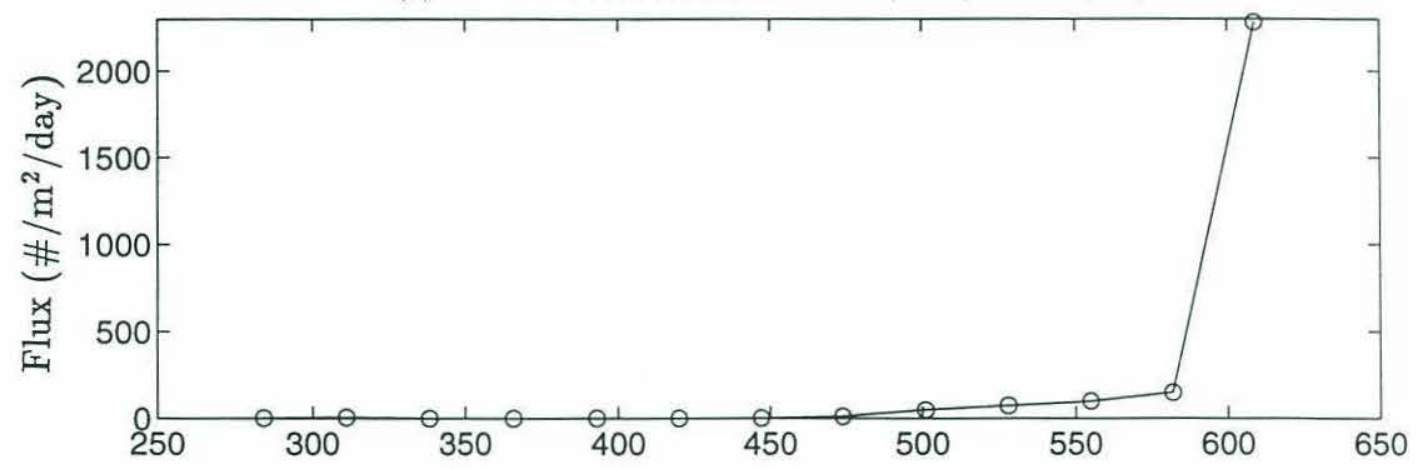

(d) IP - Relative Abundance of Foraminiferal Species

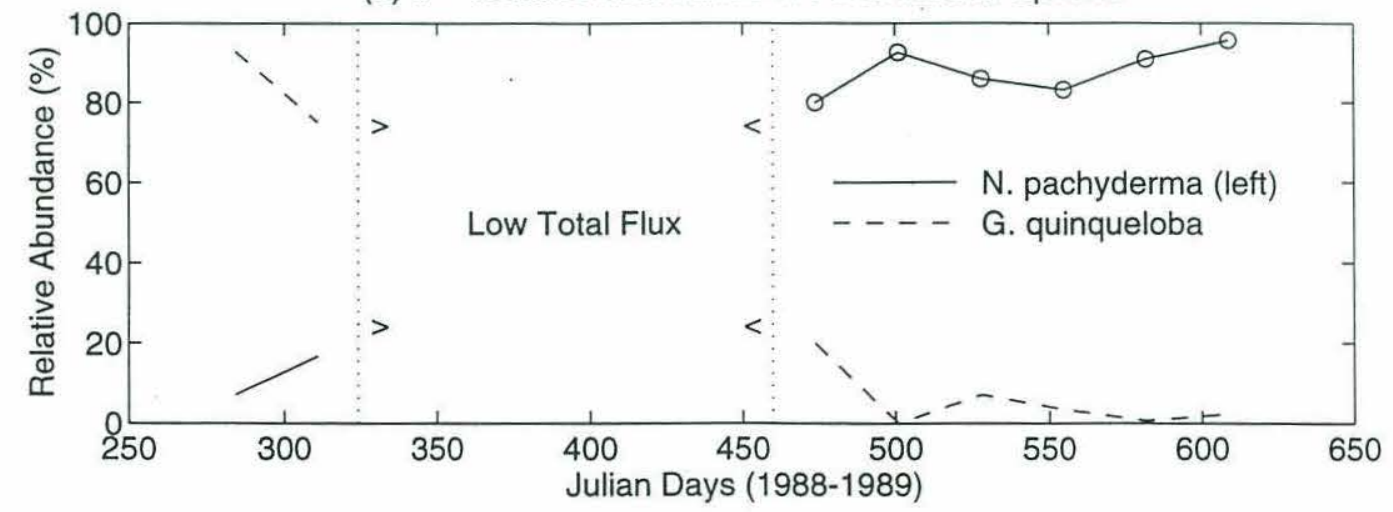




\section{Species Diversity}

The diversity among foraminiferal species collected in the four sediment traps decreases northward from JGOFS 34. Figure 11 illustrates the ranking of species at each of the four stations based on the relative abundance of species in the overall total flux (Appendix I). Only species that contribute one percent or more of the total flux at each location are included in the distributions. Figure 11 shows the classical decrease in total number of species with increasing latitude that was documented in early studies by Bé and Hamlin (1967) and Tolderlund and Bé (1971). The majority

of planktonic foraminiferal species obviously prefer the warmer surface waters in the subtropical - tropical regions. The northward decrease in faunal diversity culminates with an Arctic assemblage composed almost entirely of one species, N. pachyderma (left coiling).

\section{DISCUSSION}

\section{Total Foraminiferal Flux and the Spring Bloom}

The temporal offset of peaks in total foraminiferal flux at the four trap locations is related to the poleward migration of the spring phytoplankton bloom in the North Atlantic. The maximum foraminiferal flux recorded at each station correlates with the timing of the local peak in phytoplankton production. In the North Atlantic the spring bloom occurs in response to the seasonal development of the thermocline that shoals the mixed layer depth above the critical mixing depth (Valiela, 1984). Strong solar heating and less wind mixing induce this density stratification in the upper water column. Abundant nutrients in surface waters enhance primary production following this restratification, which directly increases the food supply for planktonic foraminifera. The phytoplankton bloom in the tropical Atlantic occurs during the winter months and is progressively delayed toward higher latitudes in the North Atlantic (Bé, 1977). Esaias et al. (1986) have documented this latitudinal shift in the seasonal timing of the spring bloom in the North Atlantic using CZCS (Coastal Zone Color Scanner) images obtained from the NIMBUS-7 satellite during 1979. The 

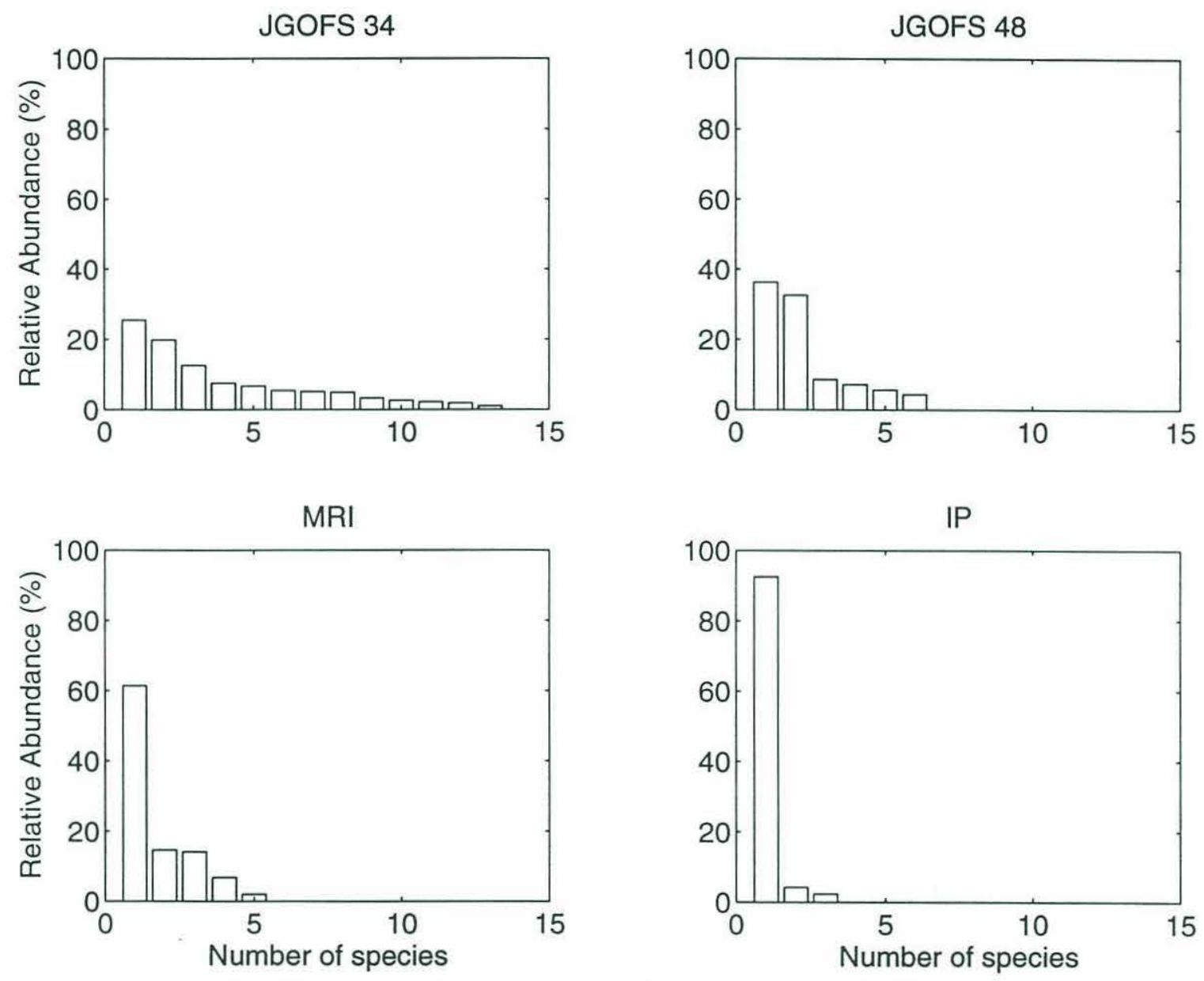

Figure 11. The ranking of species at each of the four trap sites based on their relative abundances in the overall total flux. The species number includes only those species that contribute one percent or more of the total flux at each location. The trend shown here is consistent with the classical decrease in faunal diversity with increasing latitude. The individual species can be determined from the flux data in Appendix I which are presented in the same descending order of relative abundance. 
delay in maximum primary productivity culminates with a single production peak during August in the Arctic Ocean. The seasonal shift in maximum foraminiferal flux between the four trap locations follows this primary production cycle. Flux data suggests that maximum foraminiferal production at JGOFS 34 (Figure $3 \mathrm{~b}$ ) occurs during late March - early April (JD 451 - 465), followed by a late April - early May peak (JD 479-496) at JGOFS 48 (Figure 4b). Honjo and Manganini (1993) estimated the speed of the northward progression of the spring phytoplankton bloom in this region to be $\sim 26 \mathrm{~km} \mathrm{day}^{-1}$. Figure 12 compares the timing and magnitude of total foraminiferal flux at the two JGOFS locations. The latitudinal shift in timing of the spring bloom is evident by the offset in peaks of maximum flux. Total flux maxima are further delayed to the north with June (JD 521-548) and late August - early September (JD 595-622) peaks at the MRI and IP locations, respectively (Figures 9b and $10 \mathrm{~b})$.

Total foraminiferal flux is at a maximum during local bloom periods, yet the magnitude of this high flux varies considerably with location in the North Atlantic. The highest total flux occurs at JGOFS 48 in April and May and coincides with the high primary productivity during the spring bloom in this region. The peak total flux is estimated at over $5100 \mathrm{~m}^{-2} \mathrm{day}^{-1}$ (Figure 12) and is more than twice the maximum flux recorded at any other station in this study. JGOFS 48 is in an area that was studied intensively during the 1989 JGOFS investigation of the North Atlantic spring bloom. Research vessels conducted multiple occupations in the vicinity of $47^{\circ} \mathrm{N} 20^{\circ} \mathrm{W}$ and provided important hydrographic information that was coincident with trap deployment. An overview of the multinational investigations carried out at $47^{\circ} \mathrm{N}$ is given by Lochte et al. (1993). The record of mixed layer depth at $47^{\circ} \mathrm{N}$ (Figure 13) illustrates the development of seasonal stratification in the upper water column at this location. Mixed layer thickness was over $120 \mathrm{~m}$ in the first CTD profile on April 25 (JD 481) but decreased rapidly after April 26, triggering the start of the spring bloom. Seasonal hydrographic changes in the upper water column at $47^{\circ} \mathrm{N}$ are reflected in the vertical temperature profiles in Figure 14. The thermal profile for April 25 (JD 481) represents pre-bloom conditions and reveals a 
Total Flux - JGOFS 34 and 48

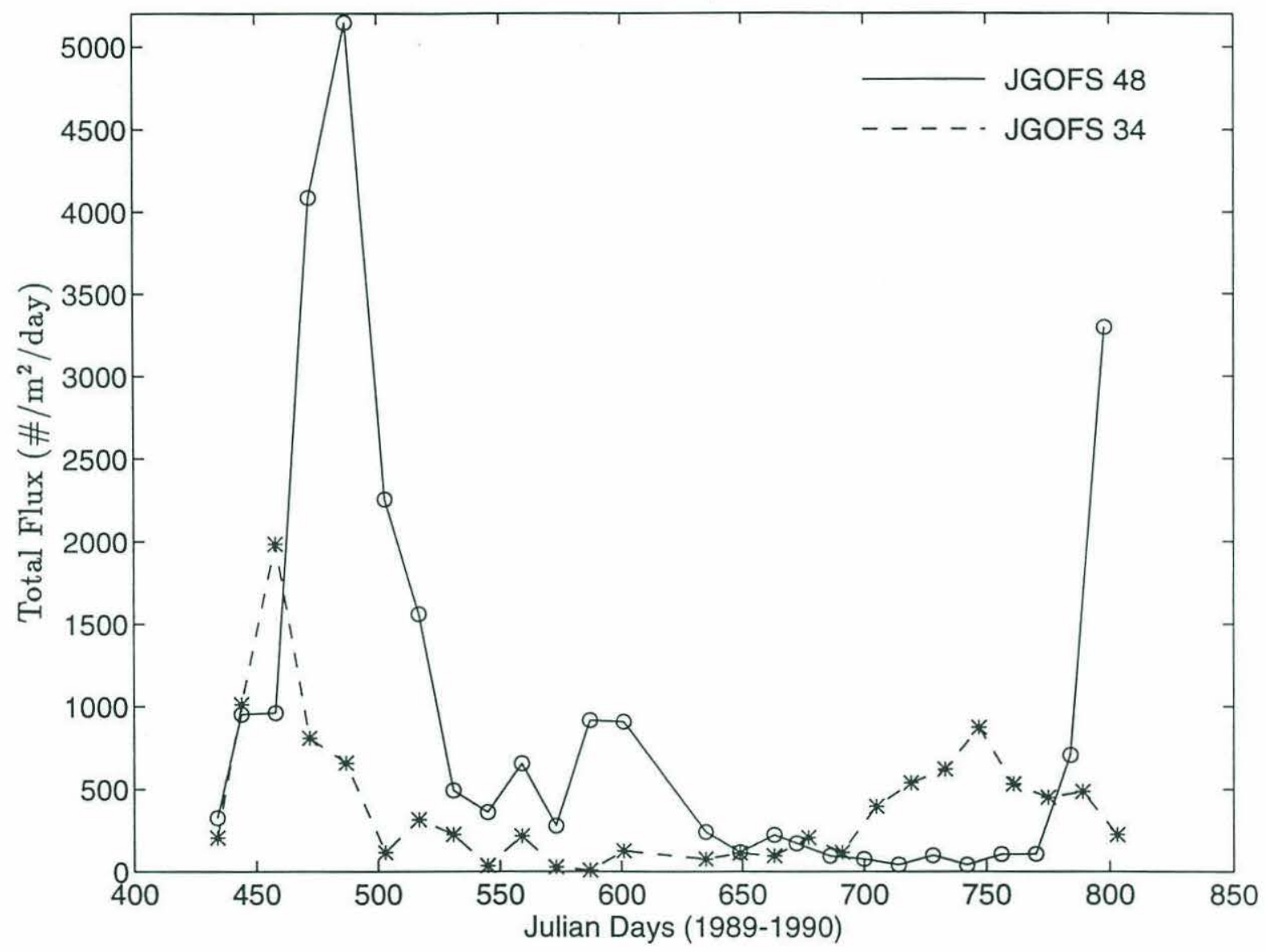

Figure 12. A comparison of the timing and magnitude of total foraminiferal flux at JGOFS 34 and JGOFS 48. Note the temporal offset of spring peaks in total flux between the two trap sites that is related to the northward progression of the spring bloom in the North Atlantic. The highest total flux recorded in this study occurs during the spring bloom at JGOFS 48 and is probably due to the proximal location of this sediment trap within the highly productive waters of the North Atlantic Current system. 


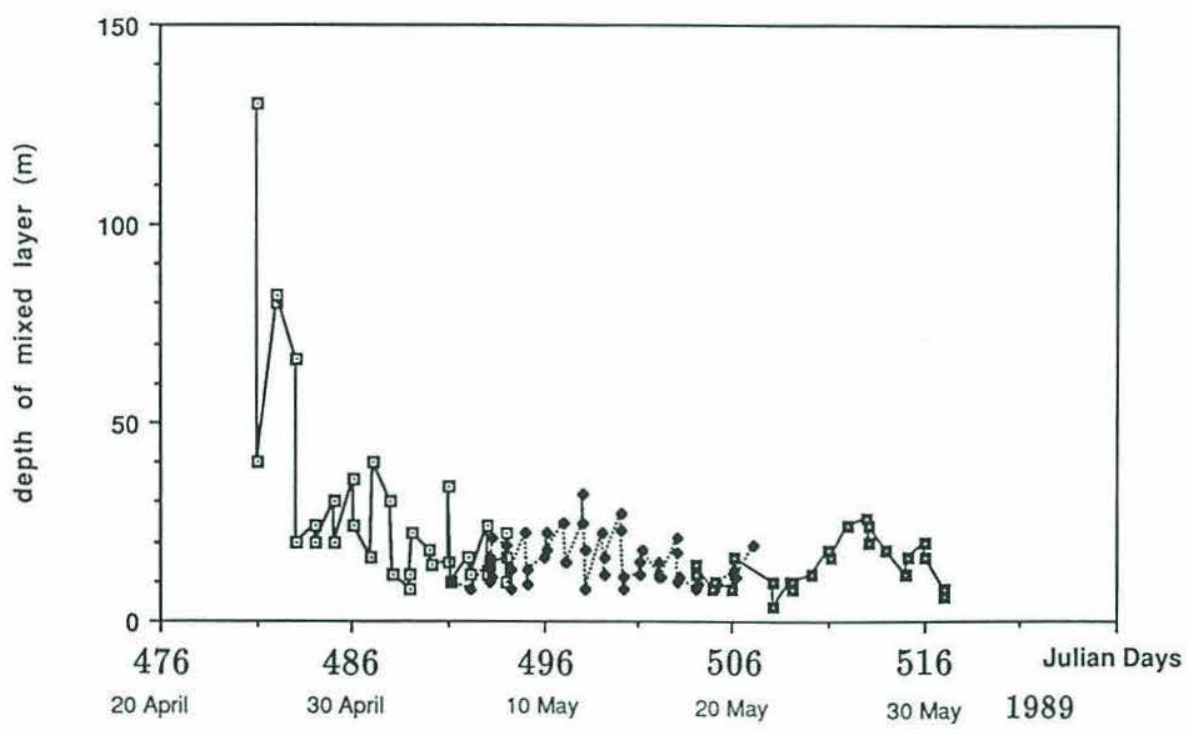

Figure 13. Depth of surface mixed layer from CTD data at $47^{\circ} \mathrm{N} 20^{\circ} \mathrm{W}$ for the period April 25 (JD 481) - May 31 (JD 517) during the JGOFS North Atlantic Bloom Experiment (NABE). The depth of this layer is computed as the depth corresponding to a temperature change of $0.02^{\circ} \mathrm{C} \mathrm{m}^{-1}$. This record illustrates the development of seasonal stratification in the upper water column in the vicinity of JGOFS 48 . The rapid decrease in mixed layer thickness after JD 482 triggers the start of the spring bloom and coincides with the period of maximum foraminiferal production at JGOFS 48. (from Lochte et al., 1993) 


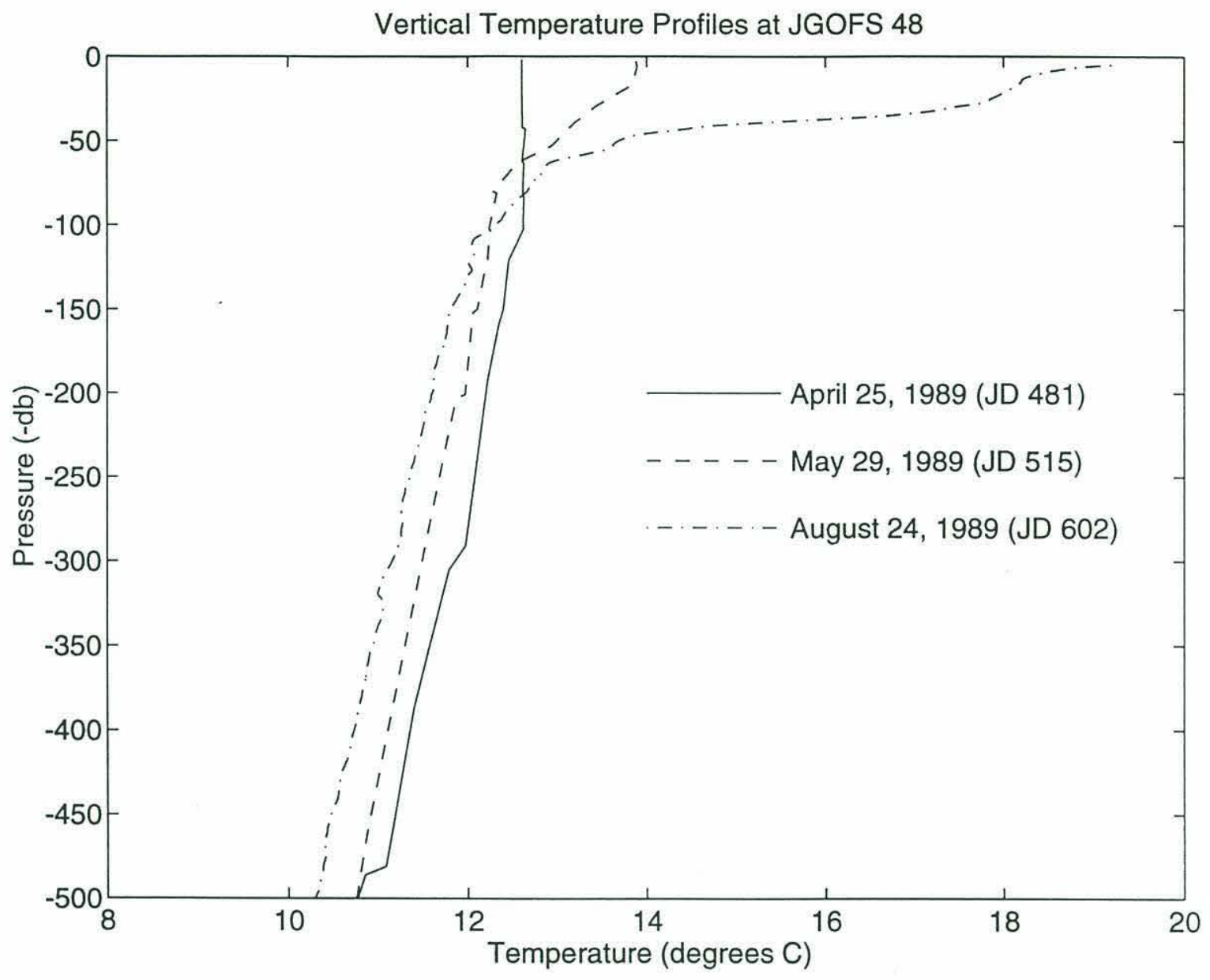

Figure 14. Vertical temperature profiles representing typical pre-bloom (April 25), post-bloom (May 29) and summer (August 24) hydrographic conditions at JGOFS 48. The profiles were derived from CTD measurements during the NABE in the vicinity of JGOFS 48. The thermal structure of the upper water column is shown to change seasonally from well-mixed to thermally stratified. 
well mixed upper water column that is essentially isothermal. The profile for May 29 (JD 515) shows the increased thermal stratification and shallower mixed layer depth that characterizes the post-bloom period. One chemical signature of the spring bloom at $47^{\circ} \mathrm{N}$ was the substantial increase in chlorophyll-a stock in the upper 80 m after April 30 (JD 486) (Lochte et al., 1993). Phytoplankton biomass reached peak concentrations during the first ten days of May and coincided with significant decreases in nutrient levels (silicate and nitrate) in surface waters (Sieracki et al., 1993). The onset of the spring bloom at $47^{\circ} \mathrm{N}$ on JD 484 (Figure 13) coincides with the period of maximum foraminiferal production at JGOFS 48 (Figure 4b), demonstrating the strong dependence of foraminiferal production on food supply.

Figure $4 \mathrm{~b}$ also shows that significant flux occurs prior to the spring bloom at JGOFS 48 before any clear indications of stratification. NABE investigations by Gardner et al. (1993) and Garside and Garside (1993) concluded that some rapid phytoplankton growth was probably initiated well in advance of the first vessel's arrival at $47^{\circ} \mathrm{N}$ on JD 481 . Prior to JD 481, the region probably experienced intervals of transient stability in the upper water column during periods of calm sunny weather. The density gradient in surface waters during these times was probably not sufficient to maintain stratification and inhibit deep mixing during storm periods (Gardner et al., 1993).

The MRI trap recorded the lowest total flux of the four stations. Foraminiferal flux during the summer never exceeded $150 \mathrm{~m}^{-2} \mathrm{day}^{-1}$ (Figure $9 \mathrm{~b}$ ). Maximum foraminiferal production occurred during June (JD 521-548) and is consistent with the timing of the predicted spring bloom in this region. A modeling study by Yentsch (1990), using parameters of nutrient distribution and light intensity, suggests that maximum primary productivity at $60^{\circ} \mathrm{N}$ in the North Atlantic should occur in June. Measurements of primary productivity and hydrography at $\sim 60^{\circ} \mathrm{N} 20^{\circ} \mathrm{W}$ during the NABE (Joint et al., 1993) support these modeling results, but the large distance from the MRI trap $\left(63^{\circ} \mathrm{N} 22^{\circ} \mathrm{W}\right)$ precludes a meaningful comparison of the data sets. The relatively low foraminiferal flux at MRI during the spring bloom can probably be attributed to its location on the Iceland shelf. The erosion of volcanic units on Iceland and 
the subsequent runoff of mafic detritus into the ocean results in highly turbid shelf waters. This turbidity may reduce light penetration in surface waters which restricts photosynthesis during bloom periods, thereby limiting the productivity of this region (Bé et al., 1977). Photosynthesis is critical for the maintenance of both an adequate food supply (phytoplankton) and the symbiotic zooxanthellae in G. quinqueloba, the most abundant foraminiferal species at this location.

The magnitude of seasonal contrast in total foraminiferal flux increases from low to high latitudes and is most pronounced at the IP location in Arctic waters because of the shorter solar season. The explosion in foraminiferal flux that occurs in August (Figure 10b) reflects the high primary productivity during the summer bloom in the Arctic Ocean. Primary productivity is very low during the winter in cold Arctic surface waters, due primarily to the low light intensity (Valiela, 1984). The low food availability results in little or no foraminiferal flux being recorded during the winter at either high latitude trap location. In addition, the surface water temperatures during winter at IP are below the tolerance ranges for most subarctic species (Bé. 1977), further restricting foraminiferal production. The sharp seasonal contrast in Arctic waters was first documented by Vilks (1973) in the Beaufort Sea who found that the summer population of Globoquadrina pachyderma was approximately 220 times greater in size than the winter population. A similar proportion is recorded in the flux data at the IP location.

\section{Mesoscale Variability at JGOFS 34 and 48}

JGOFS 34 and 48 are located in regions of high mesoscale variability which appears to contribute to the seasonality of foraminiferal production in overlying surface waters. JGOFS 34 is very close to the path of the Azores Front that was estimated by Käse and Siedler (1982) from hydrographic surveys conducted during March/April 1982 (Figure 15a). A later study (Käse et al., 1985) of the spatial eddy variability in this

region (Canary Basin) found the mesoscale eddy field confined mainly to this frontal zone associated with the Azores Current. JGOFS 48 is located in a region that has been intensely studied by previous investigators because of its proximity to the Polar 
Front, a major source of eddy production. Previous studies have observed cyclonic eddies in this area (Howe and Tait, 1967; Kupferman et al., 1986; Mittelstaedt, 1987; Krauss et al., 1990a). The eddies developed from meanders of the North Atlantic Current associated with this frontal zone. Satellite-tracked buoys deployed in the Gulf Stream by Krauss (1986) were used to clarify branches of the North Atlantic Current. Figure 15b shows the proximal location of JGOFS 48 to the buoy trajectories of Krauss (1986) and a branch of the current from the classical scheme of Dietrich et al. (1980).

Satellite altimetry (Robinson et al., 1993) revealed the presence of three cyclonic cold-core eddies in the $47^{\circ} \mathrm{N}$ study area during NABE investigations of the spring bloom. Figure 16 is a surface temperature distribution of AVHRR data from JD 483-489 that clearly shows the thermal structure of one of these detached eddies and its proximity to JGOFS 48. The onset of stratification that characterizes the early spring bloom at $47^{\circ} \mathrm{N}$ (Figure 13) coincides with the existence of this mesoscale eddy field. The characteristic doming of isotherms within cyclonic eddies is responsible for the surface temperature structure in Figure 16 and is confirmed by concurrent hydrographic surveys during the NABE (Robinson et al., 1993). Significantly colder water was introduced into the upper water column during JD 487-489 in the vicinity of $47^{\circ} \mathrm{N} 20^{\circ} \mathrm{W}$ (Marra and Ho, 1993). Vertical displacements of isotherms of $150 \mathrm{~m}$ are not uncommon within eddies in this region of the Atlantic (Krauss and Käse, 1984). The eddy in Figure 16 occurs during the period of maximum foraminiferal production at JGOFS 48 (Figure 4b). The structure of chlorophyll fields sensed by Airborne Oceanographic Lidar (AOL) during the NABE (Yoder et al., 1993) indicates that the amount of chlorophyll-a inside the eddy cores increased by a factor of two over the peripheral water mass. The shoaling of density surfaces, resulting from cyclonic circulation, significantly increases the supply of nutrients to the euphotic zone, causing the local spatial variability in phytoplankton production. An increased food supply within the eddy enhances foraminiferal production, resulting in the higher vertical flux from surface waters.

Kupferman et al. (1986) and Mittelstaedt (1987) described an eddy in this re- 


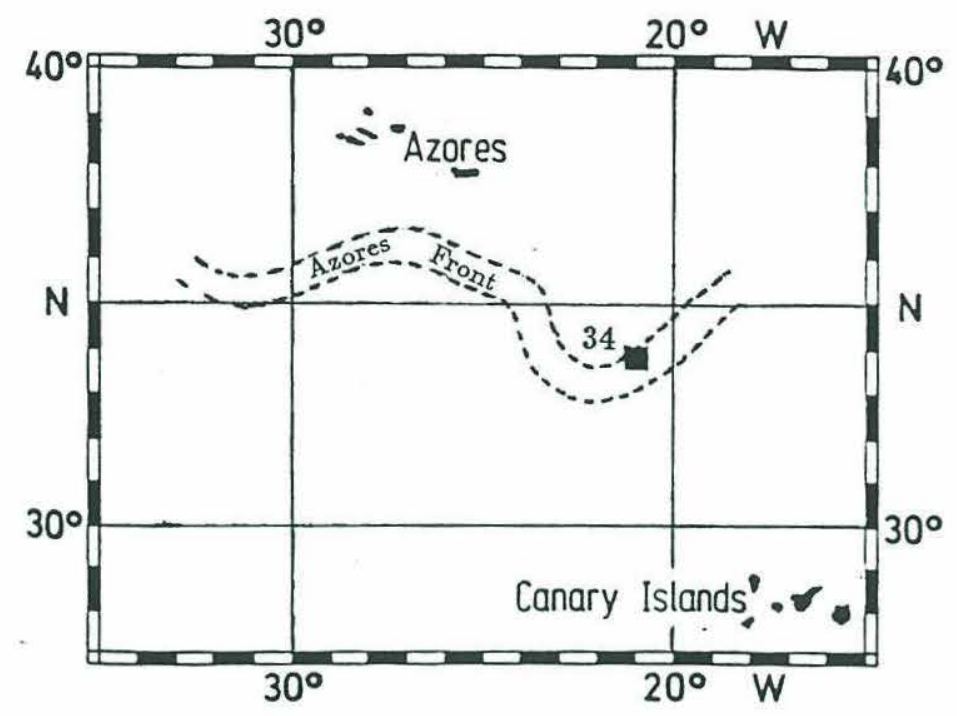

(a) Map from Käse and Siedler (1982) shows the close proximity of JGOFS 34 ( $\square$ ) to the estimated position of the Azores subtropical front.

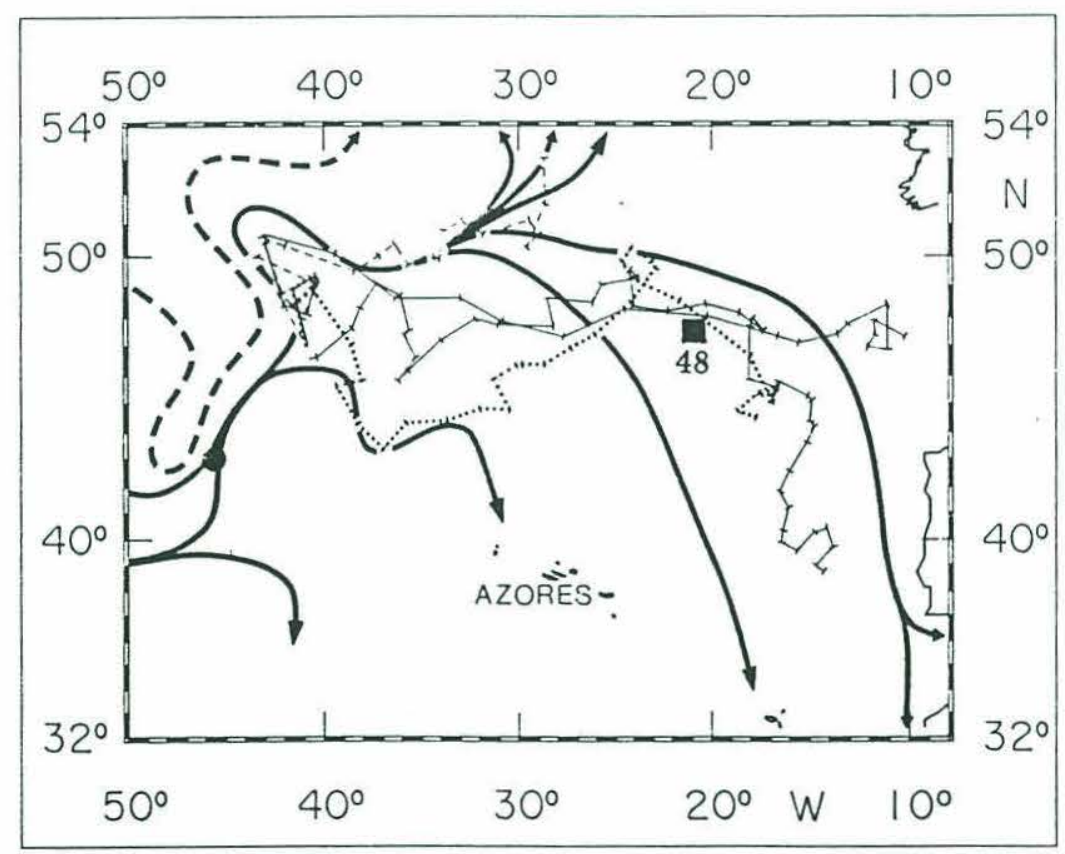

(b) Map showing the path of the North Atlantic Current according to Dietrich et al. (1980) (solid lines) and the buoy trajectories of Krauss (1986). The position of JGOFS 48 ( $\square$ ) is shown within the current system near the Polar Front. (from Krauss, 1986)

Figure 15. Maps showing the proximal location of the JGOFS sediment traps to important frontal zones in the North Atlantic that are also major sources of mesoscale variability. 
gion during the spring bloom of 1985 . This eddy is considered analogous to the mesoscale eddies observed near JGOFS 48 in 1989. A huge current meander was detected in late April 1985 that cut off and formed a well-developed cyclonic eddy by early May at $\sim 48^{\circ} \mathrm{N} 22^{\circ} \mathrm{W}$ (Kupferman et al., 1986). Surface temperatures of core water were $\sim 1.5^{\circ} \mathrm{C}$ lower than the surrounding water mass (Mittelstaedt, 1987) which compares well with the eddy in Figure 16. The surface mixed layer within the eddy was also characterized by high concentrations of chlorophyll-a and phytoplankton biomass (Lochte and Pfannkuche, 1987). The coincidence of intense mesoscale variability during the early spring bloom in this area indicates that cyclonic eddies may play an important role in maintaining the high biological production during the bloom period at JGOFS 48. Local nutrient supplies in surface waters may be efficiently resupplied after stratification by mixing associated with the eddy field (Garside and Garside, 1993). The proximal location of JGOFS 48 within the North Atlantic Current system probably ensures a continual replenishment of nutrients and a high phytoplankton biomass during bloom periods, which enhances foraminiferal production.

A secondary peak in foraminiferal flux $\left(\sim 910 \mathrm{~m}^{-2}\right.$ day $\left.^{-1}\right)$ during August (JD 580608 ) at JGOFS 48 (Figure $4 \mathrm{~b}$ ) is also associated with a prominent mesoscale feature on AVHRR imagery. The SST structure during JD 587-593 in Figure 17 depicts JGOFS 48 within a large meander of the North Atlantic Current. The current in Figure 17 appears to follow an easterly course and exhibits three successive meanders. Closed temperature contours within the two easternmost meanders indicate that newly formed eddies are developing from the meanders but still remain attached to the parent current. Cyclonic circulation associated with the meander near JGOFS 48 would shoal the thermocline in this region and displace nutrients toward the surface, effectively stimulating foraminiferal production in the upper water column. The subsurface thermal structure of the eddy field in this area may be more highly developed than is indicated by the surface temperature signals in Figure 17. The strong thermocline and thermal isolation of the surface layer in August (Figure 14) may inhibit the complete upward intrusion of colder nutrient-rich waters to the surface 


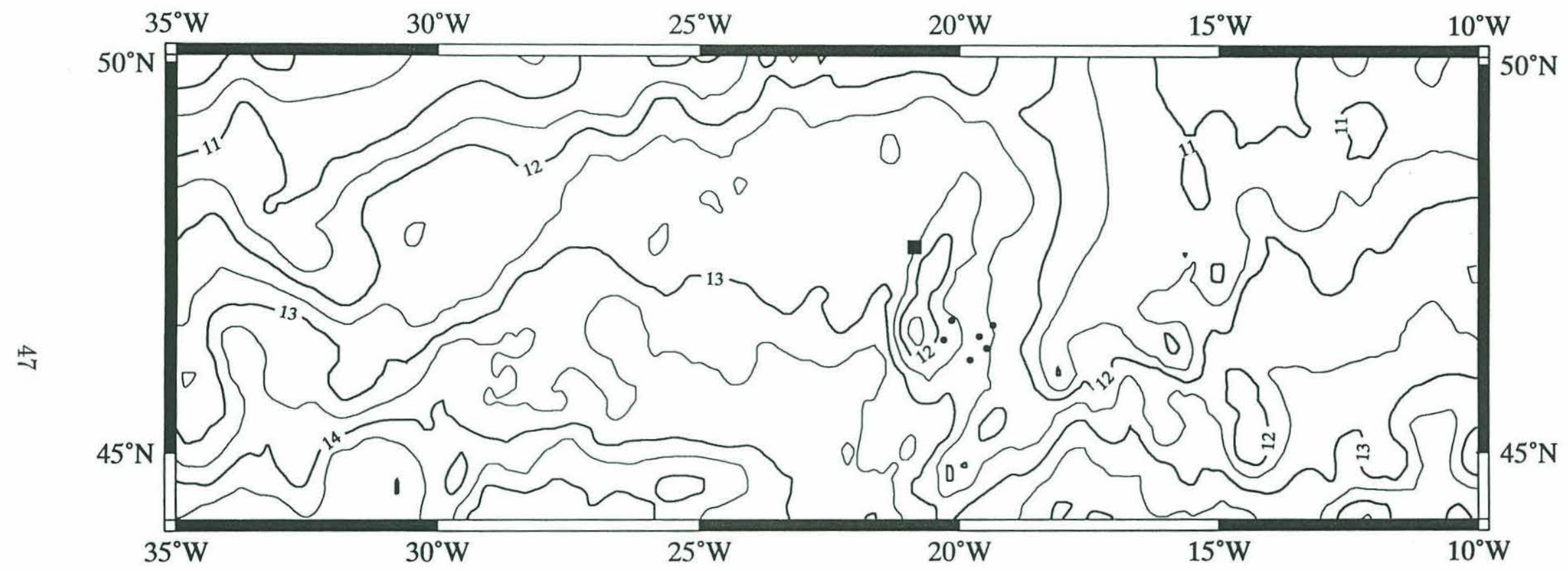

Figure 16. SST distribution from AVHRR data for April 27 - May 3. 1989 (JD 483-489) in the North Atlantic around JGOFS 48 ( $\mathbf{\square})$. A cyclonic cold-core eddy recently detached from the Polar Front is shown in the vicinity of the trap station. The small filled circles mark the locations of concurrent hydrographic surveys conducted during the NABE that confirmed the presence of the eddy and its subsurface thermal structure. 
and thus suppress SST variations. Unfortunately, no concurrent hydrographic data are available for this period to support this remotely sensed data.

A period of high foraminiferal flux during the winter at JGOFS 34 (Figure 3b) peaks at over $870 \mathrm{~m}^{-2} \mathrm{day}^{-1}$ (JD 740-754) and is also associated with significant mesoscale variability. This region was less well studied than the $47^{\circ} \mathrm{N}$ site during the NABE but AVHRR data in this study show a meandering SST pattern in the vicinity of JGOFS 34 coincident with the high flux interval. Figure 18 is a sequence of eight weekly SST distributions that illustrates the development of a meander in the Azores Current during a two month period (JD 714-776). The frontal region associated with this current is recognized by the congestion of isotherms along $\sim 35^{\circ} \mathrm{N}$. The SST decreases at JGOFS 34 during JD 714-748 (Figure 18a-e) and reflects the development and extension of a frontal meander into the trap area. The meander appears to be best developed in Figure 18d-e (JD 735-748) during the period of maximum foraminiferal flux (JD 740-754). Eddy formation is also evident during this time (Figure 18d-e) and provides the necessary mechanism for transferring nutrients into the mixed layer to increase production. A subsequent temperature increase occurs at JGOFS 34 as the meander dissipates to the north (Figure 18h) and foraminiferal flux begins decreasing.

\section{Species Succession and Preferred Production Periods}

The latitudinal variation in the absolute abundance of foraminiferal species is related to the preferred temperature habitats of individual species. Bé and Tolderlund (1971) determined optimal temperature ranges and grouped the modern planktonic species into five faunal provinces. The species assemblages in the four faunal zones represented in this study are generally consistent with these previous classifications. Warm water species such as G. ruber are virtually absent north of JGOFS 34 (subtropical). The cold water species G. quinqueloba and N. pachyderma (left coiling) are highest in concentration at the MRI (subarctic) and IP (arctic) stations but are virtually absent in the JGOFS traps to the south. Since most planktonic species have temperature tolerance ranges, a pattern of seasonal succession can occur in a region as species dominance shifts with seasonal changes in SST. In this study, the 


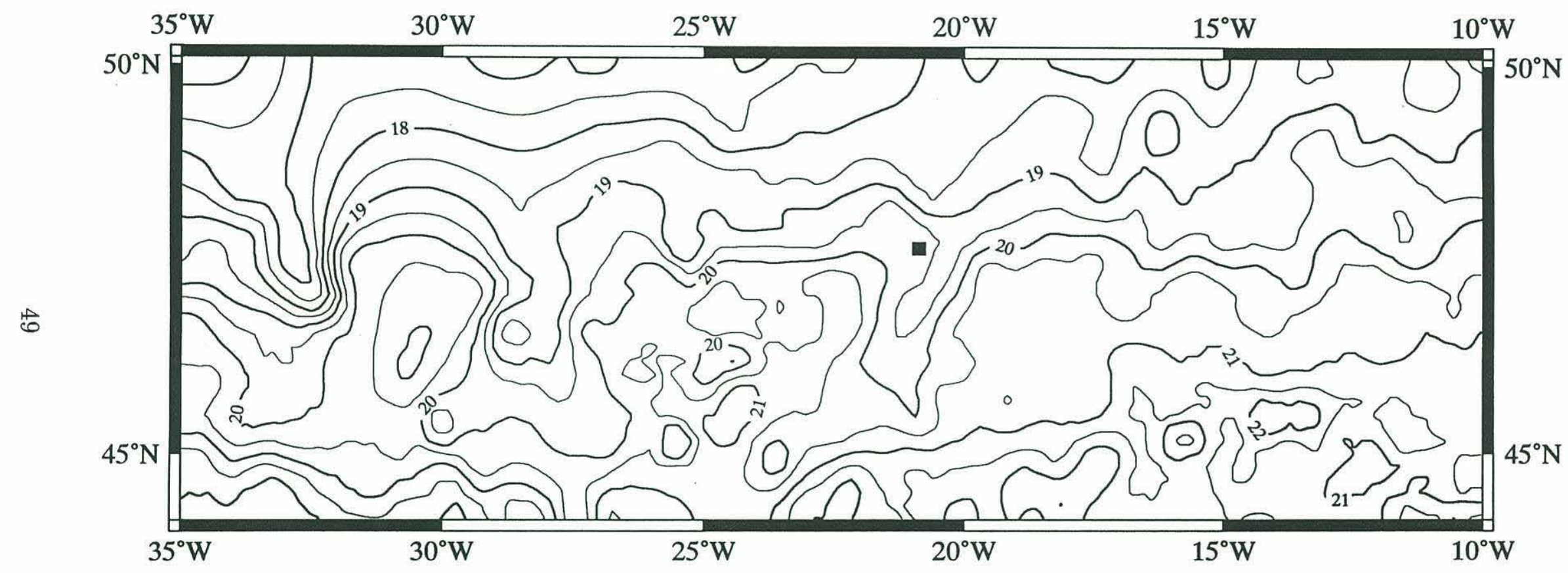

Figure 17. SST distribution from AVHRR data for August 9-15, 1989 (JD 587593 ) in the North Atlantic around JGOFS 48 ( $)$ ). A meandering SST pattern is shown in the vicinity of the trap station. Closed temperature contours within meanders indicate cyclonic eddy activity in the area that coincides with a period of high foraminiferal production during August (JD 580-608) at JGOFS 48. 
scheme of dominance is not particularly obvious in absolute abundance data (Figures 5 and 6 ) because the production peaks of individual species collected in the traps often correspond with the timing of the local spring bloom. The dominant species are more easily recognized in the relative abundance data which presents the species as a percent of the total flux.

\section{JGOFS 34}

Most foraminiferal species at JGOFS 34 attain peak production levels (Figure 5) during the hydrographic conditions associated with the spring bloom. The flux of G. bulloides increases most dramatically during the early spring (Figure 5a). This finding is in accord with previous studies (Thunell and Reynolds, 1984; Reynolds and Thunell, 1985; Sautter and Thunell, 1989; Curry et al., 1992) suggesting a rapid response of this species to increased food availability in the upper water column. G. bulloides also dominates the foraminiferal assemblage at JGOFS 34 during the period of winter upwelling associated with mesoscale eddy activity, however, G. glutinata (Figure 5c) and G. inflata (Figure 5e) also exhibit preferred production periods at this time. G. glutinata is a eurythermal species (Tolderlund and Bé, 1971) that is considered "opportunistic" because it increases production whenever food is available (Sautter and Thunell, 1991). Although it seems to prefer warm water environments, G. glutinata also thrives in the nutrient-rich waters associated with upwelling (Thunell and Reynolds, 1984). G. inflata is not an abundant species at JGOFS 34, but it does increase significantly in production during the winter (Figure 5e) when SST (Figure 3a) falls within its optimal range $\left(13-19^{\circ} \mathrm{C}\right.$ : Bé and Tolderlund, 1971).

The relative abundance data presented in Figure 7 shows a seasonal shift in species dominance at JGOFS 34 between G. bulloides (winter - early spring) and G. ruber (spring - fall). G. ruber is the dominant species for about eight months of the year but only during seasons of low productivity. Relatively low foraminiferal flux is recorded during the summer at JGOFS 34 because of the higher summer temperatures that result in intense thermal stratification and nutrient depletion. The maximum summer SST $\left(\sim 25^{\circ} \mathrm{C}\right)$ also exceeds the tolerance range of most non-tropical planktonic 
Figure 18. A sequence of eight weekly SST distributions from AVHRR data for

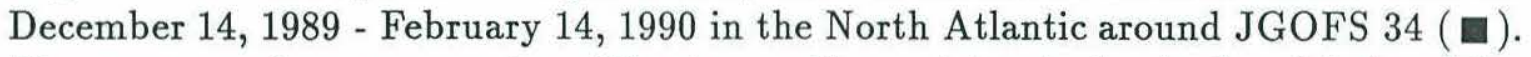
The sequence shows a meander of the Azores Current developing in the vicinity of the trap station during a two month period. The meandering flow appears most highly developed in (d) and (e) when it shows evidence of cyclonic eddy activity. The eddy activity coincides with a peak period of foraminiferal production (JD 740-754) at JGOFS 34 . 
(a) December 14-20, 1989 (JD 714-720)

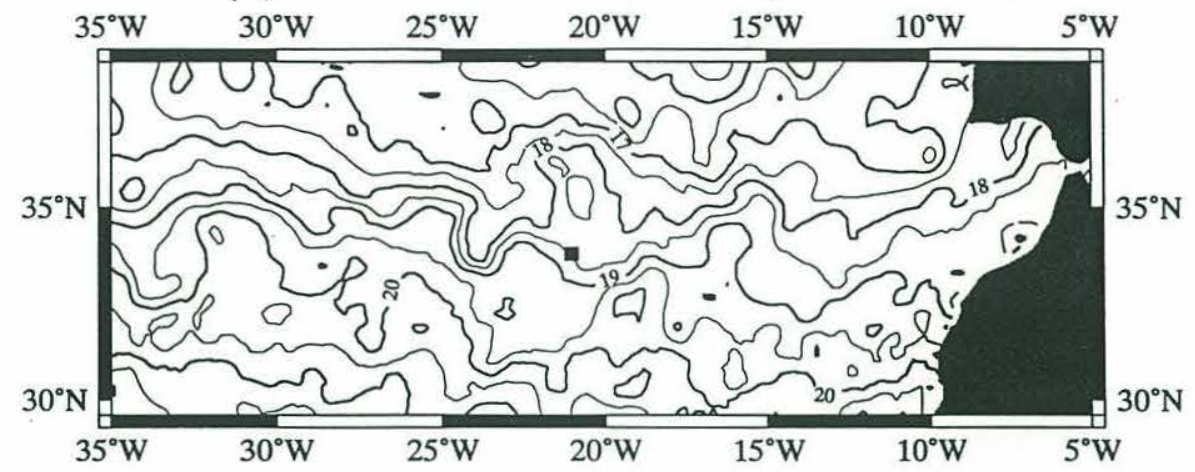

(b) December 20-26, 1989 (JD 720-726)

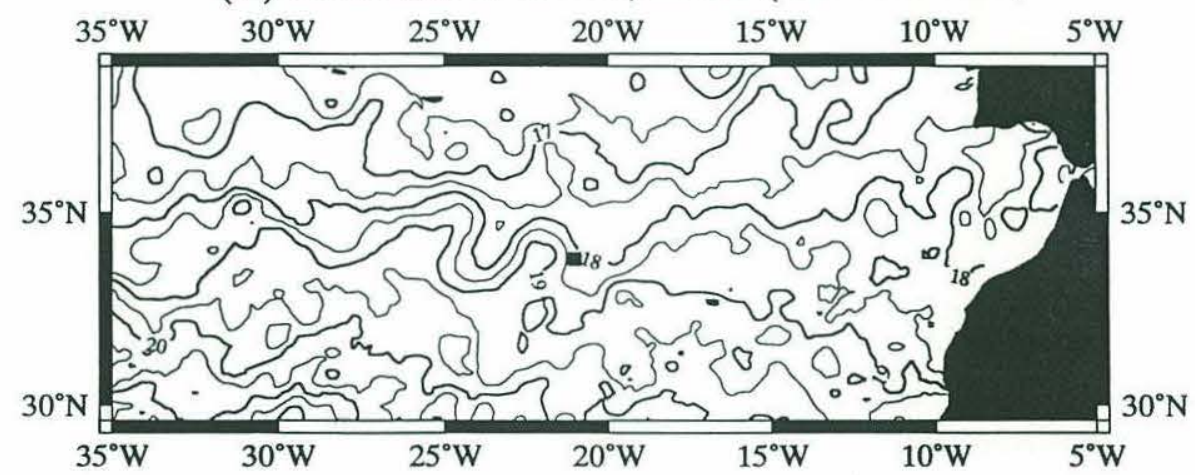

(c) December 28-January 3, 1989-90 (JD 728-734)

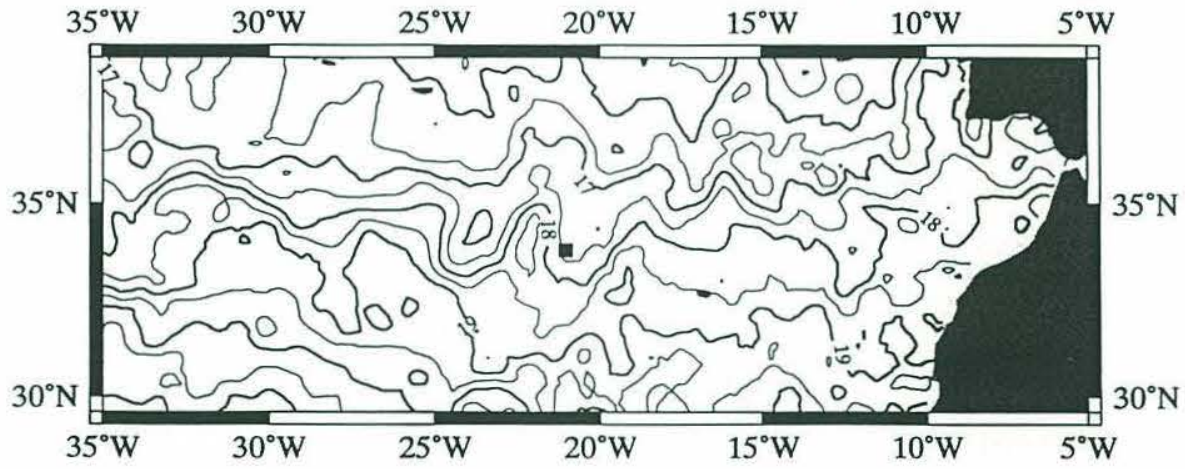

(d) January 4-10, 1990 (JD 735-741)

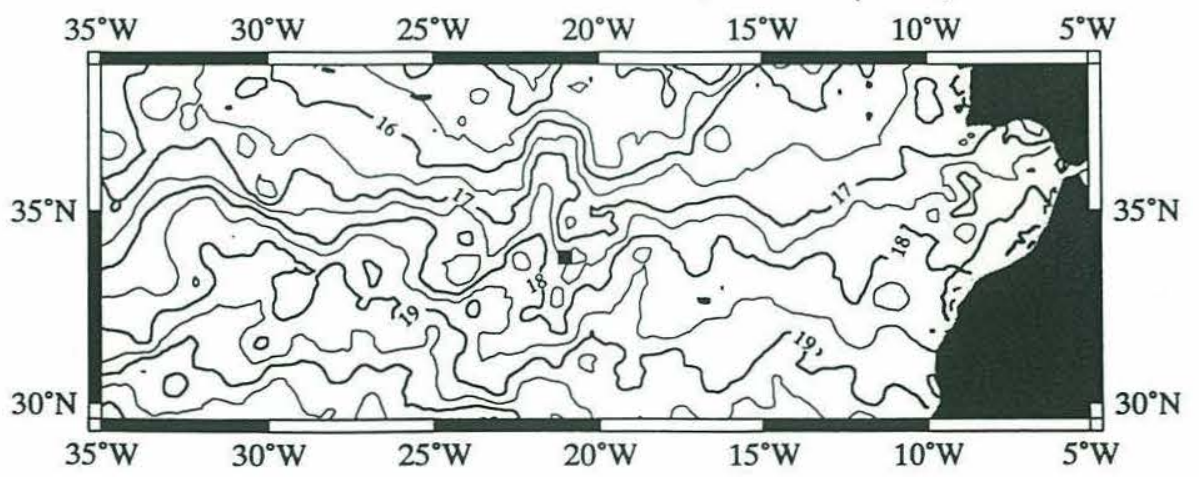


(e) January 11-17, 1990 (JD 742-748)

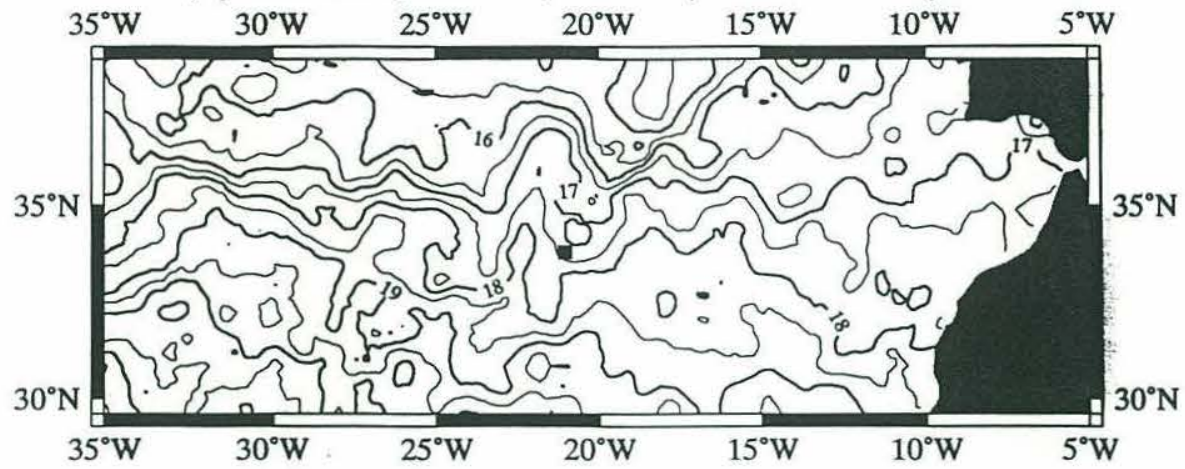

(f) January 25-31, 1990 (JD 756-762)

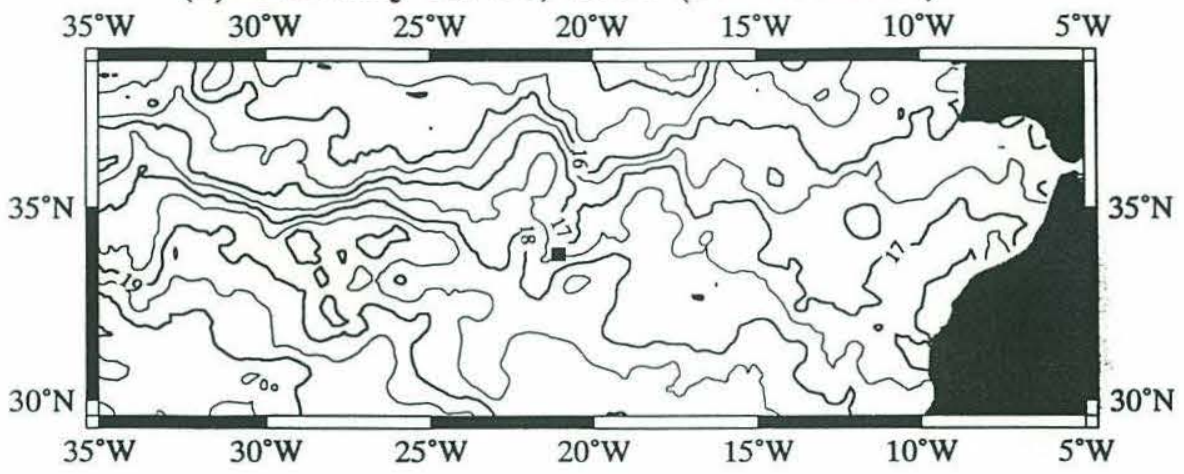

(g) January 31-February 6, 1990 (JD 762-768)

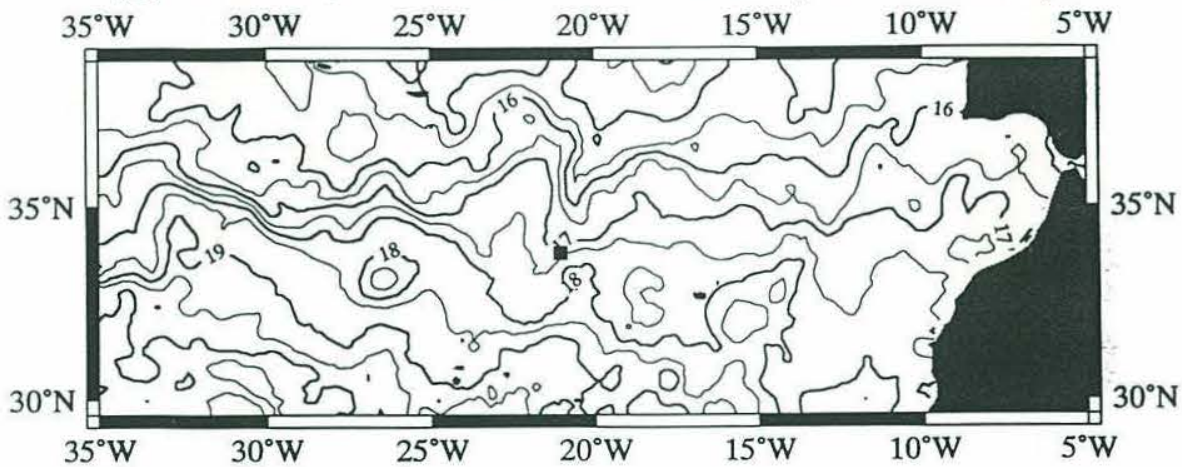

(h) February 8-14, 1990 (JD 770-776)

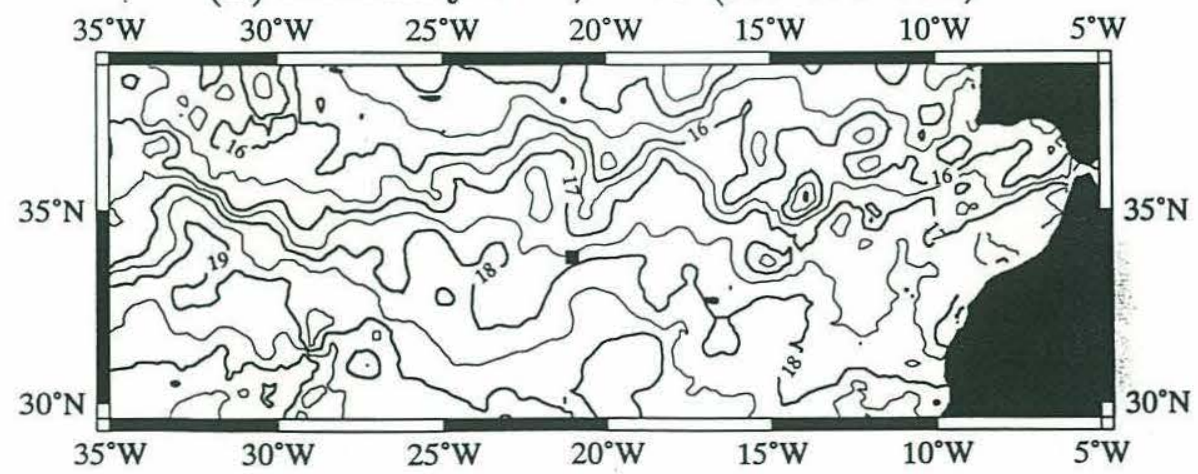


species (Bé and Tolderlund, 1971). G. ruber appears to be the only species able to survive at appreciable production levels throughout the summer (Figure 5b). Shifts in dominance between $G$. bulloides and $G$. ruber are indicated by crossovers at about JD 475 and JD 715 in Figure 7. The crossover points occur during the warming and cooling of surface waters at a SST of $\sim 18.5^{\circ} \mathrm{C}$. This apparent symmetry suggests that the seasonal succession of these two species is primarily controlled by seasonal changes in SST. A SST of $18.5^{\circ} \mathrm{C}$ appears to be above the optimal temperature range for $G$. bulloides but is clearly lower than the ideal range for G. ruber.

\section{JGOFS 48}

The maximum flux periods of foraminiferal species at JGOFS 48 (Figure 6) are strongly correlated with the timing of the spring bloom, as was previously shown for JGOFS 34. G. bulloides and N. pachyderma (right coiling) are the two most abundant species, together constituting nearly $70 \%$ of the overall total flux (Appendix I). The relative abundance data (Figure 8), however, illustrate a seasonal succession at JGOFS 48 that includes five different species. The relative abundance of G. bulloides (Figure $8 \mathrm{~b}$ ) is conspicuously low during the late summer and winter. The near absence of $G$. bulloides at extremes in SST implies an annual SST range that spans the optimal temperature range for this species. G. bulloides dominates the assemblage during the fall at JGOFS 48, but a distinct succession of dominant species occurs during the cooling of surface waters. The temporal placement of relative abundance peaks for G. inflata, G. glutinata, and G. scitula (Figure 8c-e) define a seasonal succession at winter temperatures that are probably below the optimal range of G. bulloides. In this study, G. inflata is most abundant at JGOFS 48 which is to be expected since this species is the only one indigenous to the Transitional zone. The broad peak in relative abundance exhibited by $G$. inflata (Figure 8c) correlates well with the optimal temperature range $\left(13-19^{\circ} \mathrm{C}\right)$ for this species determined by Bé and Tolderlund (1971). When the SST falls below $\sim 13^{\circ} \mathrm{C}, G$. inflata is replaced as the dominant species by

the ubiquitous G. glutinata (Figure 8d). Species dominance then shifts to G. scitula (Figure 8e) during further cooling of surface waters. The colder tolerance of G. scitula 
is consistent with its classification as a subarctic species by Bé and Tolderlund (1971).

N. pachyderma (right coiling) is the dominant species at JGOFS 48 (Figure 8a) during maximum summer temperatures that may exceed the optimal temperature range for $G$. bulloides. A study in the northeast Pacific at $50^{\circ} \mathrm{N}$ (Reynolds and Thunell, 1986) also found N. pachyderma (right) to increase in abundance during warmer summer months at times of high phytoplankton production. Figure $6 \mathrm{~b}$ illustrates a distinct seasonal peak in production for $N$. pachyderma at JGOFS 48 that coincides with the period of high mesoscale eddy production (Figure 17) during the late summer. The competition for food (i.e., phytoplankton) during upwelling may be reduced by the near-absence of the larger G. ruber and G. bulloides. Less competition could contribute to a significant increase in the production of $N$. pachyderma as suggested by Reynolds and Thunell (1985) for the North Pacific. The preferred deep habitat for this species also plays an important role in its higher summer production and will be addressed in the following section.

\section{MRI and IP}

The high latitude flux data (MRI and IP) exhibit no obvious pattern of seasonal succession among the cold water species. This is due primarily to the low species diversity and smaller seasonal temperature variations in the Subarctic and Arctic zones. The overall dominance of G. quinqueloba at MRI during the spring and summer is consistent with a typical subpolar assemblage (Bé and Tolderlund, 1971). G. bulloides production is suppressed year-round because the SST remains below the optimal range for this species. The near-total dominance of $N$. pachyderma (left coiling) at the IP station is predictable since this is the only species indigenous to Arctic waters. 


\section{TEMPERATURE RANGES AND ECOLOGY OF INDIVIDUAL SPECIES}

The application of time correction factors to foraminiferal flux data in this study allows the SST during initial shell production to be estimated from the weekly satellite data. Using this method, the variations in relative abundance of individual species can be evaluated as a function of temperature. Preferred temperature ranges of some individual species have been identified and are discussed along with ecological inferences derived from these results.

\section{Globigerinoides ruber}

G. ruber is considered to be the most prolific warm-water species in the Atlantic in terms of both distribution and abundance (Bé, 1977). It is most abundant in the Subtropical zone and is second only to G. sacculifer in tropical waters (Tolderlund and Bé, 1971). G. ruber is a spinose species possessing symbiotic algae which implies a near-surface habitat. Isotopic studies by Deuser et al. (1981), Fairbanks et al. (1982), Curry et al. (1983), and Deuser (1987) rank G. ruber as the shallowest dwelling planktonic species, making it one of the best paleoceanographic indicators of near-

surface temperature change. Since it lives closest to the surface, the correlation of satellite-derived SST with the relative abundance of this species is probably the most accurate in this study.

In the study area, $G$. ruber reaches its maximum relative abundance during the SST maxima at JGOFS 34 (Figure 7). Figure 19 shows the relative abundances of $G$. ruber at JGOFS 34 and 48 plotted against SST with a least squares regression line fitted to the data. The positive slope of this regression indicates a direct correlation of $G$. ruber concentration with SST. The regression for the data in Figure 19 is:

$$
R=8.4 S S T-133
$$

where $R$ is the relative abundance (\%) of G. ruber in the total flux and SST is the estimated sea surface temperature $\left({ }^{\circ} \mathrm{C}\right) 27$ days prior to the midpoint of the two week flux averaging period. The regression line predicts a low relative abundance 


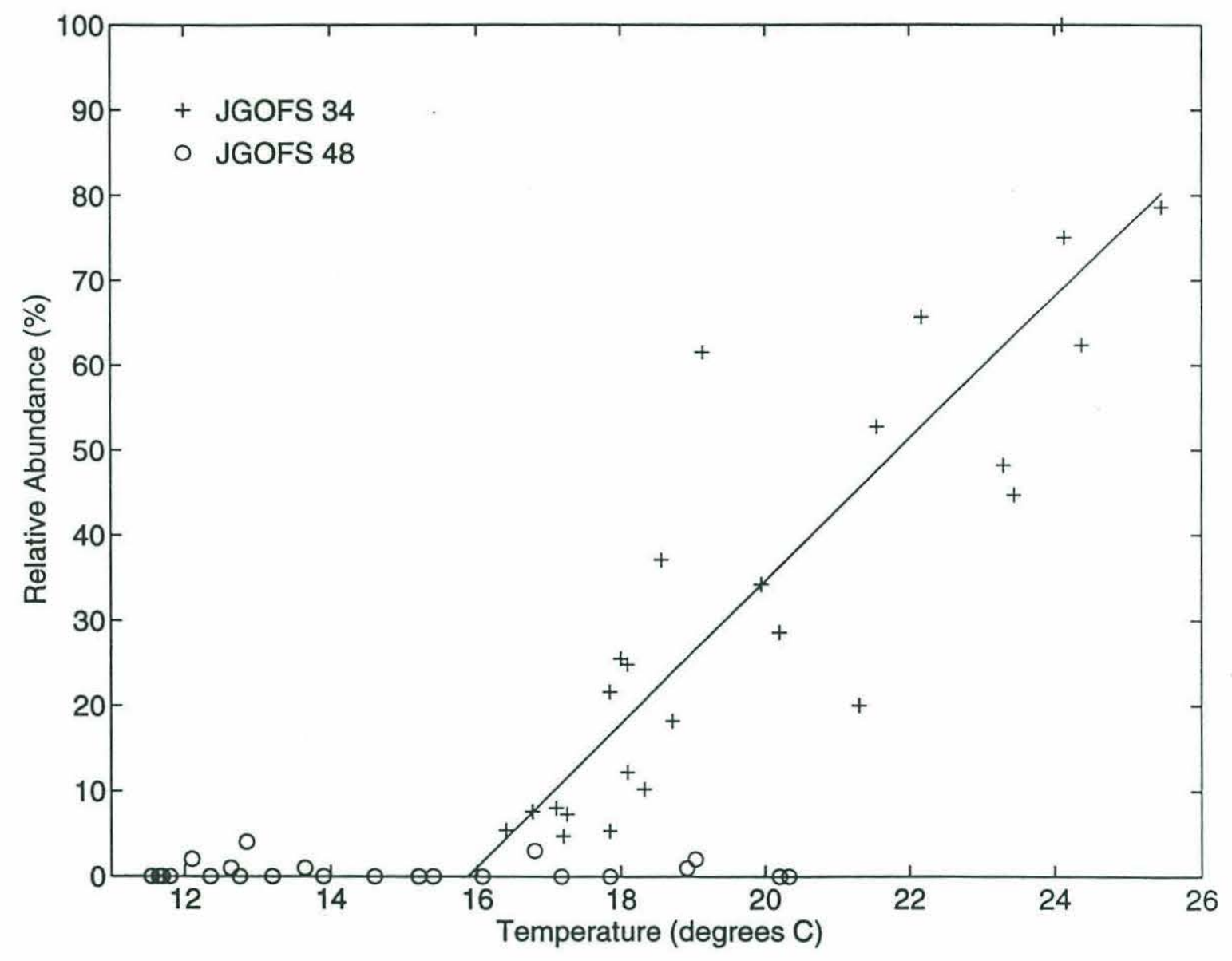

Figure 19. The relative abundance (in \%) of G.ruber in the total flux is plotted against SST for samples from JGOFS 34 and 48. A least squares regression line is fitted to this data and shows a positive correlation of $G$. ruber concentration with SST. 
of $G$. ruber when the SST falls below $\sim 18^{\circ} \mathrm{C}$. The zero intercept indicates that the species should not tolerate surface temperatures much below $16^{\circ} \mathrm{C}$. This lower limit is consistent with the tolerance range $\left(16-31^{\circ} \mathrm{C}\right)$ determined by Hemleben et al. (1989) from laboratory cultures. These results are also consistent with the low concentration of $G$. ruber during winter temperatures at JGOFS 34 when it is replaced as the dominant species by $G$. bulloides. The summer temperature maxima at JGOFS 34 were not high enough to test the upper end of the tolerance range for this species, estimated at $31^{\circ} \mathrm{C}$ by Hemleben et al. (1989).

The application of the linear regression line in Figure 19 to flux data and fossil assemblages may be limited to the Subtropical zone in the North Atlantic. The peak summer temperatures at JGOFS $48\left(\sim 20^{\circ} \mathrm{C}\right)$ in the Transitional zone are within the tolerance range for $G$. ruber but apparently did not last long enough for the species to establish itself in the population. The application of these results to the Tropical zone is limited because of the co-dominance of G. sacculifer, another warm-water spinose species. G. ruber and G. sacculifer are considered competitive species in the tropics that have adapted to the same ecological niche (Bé and Tolderlund, 1971). G. sacculifer is relatively sparse at JGOFS 34, probably because of its preference for slightly warmer surface temperatures $\left(>24^{\circ} \mathrm{C}\right.$ ) (Thunell and Reynolds, 1984) and intermediate surface salinities (Bé and Tolderlund, 1971). G. ruber, on the other hand, can tolerate the higher average salinities of North Atlantic central waters in the vicinity of JGOFS 34. The absence of significant competition from G. sacculifer results in the complete dominance by $G$. ruber during the summer at JGOFS 34 . When the effects of species competition are reduced, there is a more positive correlation between the relative abundance of $G$. ruber and SST.

\section{Globigerina bulloides}

G. bulloides is the most prolific species in the study area, having significant concentrations at three of the four trap locations (Appendix I). G. bulloides is a spinose foraminifera that also prefers the surface mixed layer above the thermocline (Fairbanks et al., 1982; Thunell and Reynolds, 1984). It is thus strongly affected by 
changes in SST, although its absolute abundance in this study appears to be more directly controlled by variations in primary production. The high productivity and wide areal distribution of $G$. bulloides in this study provide for a large quantity of flux data over a wide temperature range, making it ideal for determining the optimal SST range for this species.

Relative abundance data for $G$. bulloides from all four trap locations are plotted against temperature in Figure 20. A least squares Gaussian distribution $(\bar{x}=15.3$, $\sigma=3$ ) is also fitted to this data. According to Figure 20 the maximum relative abundance of $G$. bulloides occurs at $\sim 15^{\circ} \mathrm{C}$. The shift in dominance at JGOFS 34 between G. ruber and $G$. bulloides occurs at $\sim 18.5^{\circ} \mathrm{C}$ or at about one standard deviation from the mean of the normal distribution. It is only during the winter at JGOFS 34 that SST $\left(<18^{\circ} \mathrm{C}\right)$ approaches the optimal temperature range, and $G$. bulloides becomes the dominant species. G. bulloides exhibits greater dominance at JGOFS 48 because the annual SST range $\left(11-20^{\circ} \mathrm{C}\right)$ extends completely across the optimal range for this species.

\section{Neogloboquadrina pachyderma}

N. pachyderma is considered the most important cold-water species of planktonic foraminifera in paleoceanography. Its importance comes from the use of its coiling direction as a paleoclimatic indicator. The boundary between right and left coiling populations of $N$. pachyderma was shown by Bé and Hamlin (1967) to be associated with the $7.2^{\circ} \mathrm{C}$ surface isotherm in the North Atlantic. The dominance of left or right coiling tests in the $N$. pachyderma population are used to distinguish between the Arctic and Subarctic provinces, respectively (Bé, 1977).

The flux data in this study are consistent with previous work relating the dominance shift between the two coiling forms to SST. The percentage ratios of left versus right coiling $N$. pachyderma tests are plotted against SST in Figure 21. The SST at IP is below $7^{\circ} \mathrm{C}$ almost year-round, and the $N$. pachyderma flux is completely dominated by left coiling forms. The MRI and JGOFS locations show a predominance of right coiling forms at temperatures above $8^{\circ} \mathrm{C}$. The curve intercept at $50 \%$ (left coiling) 


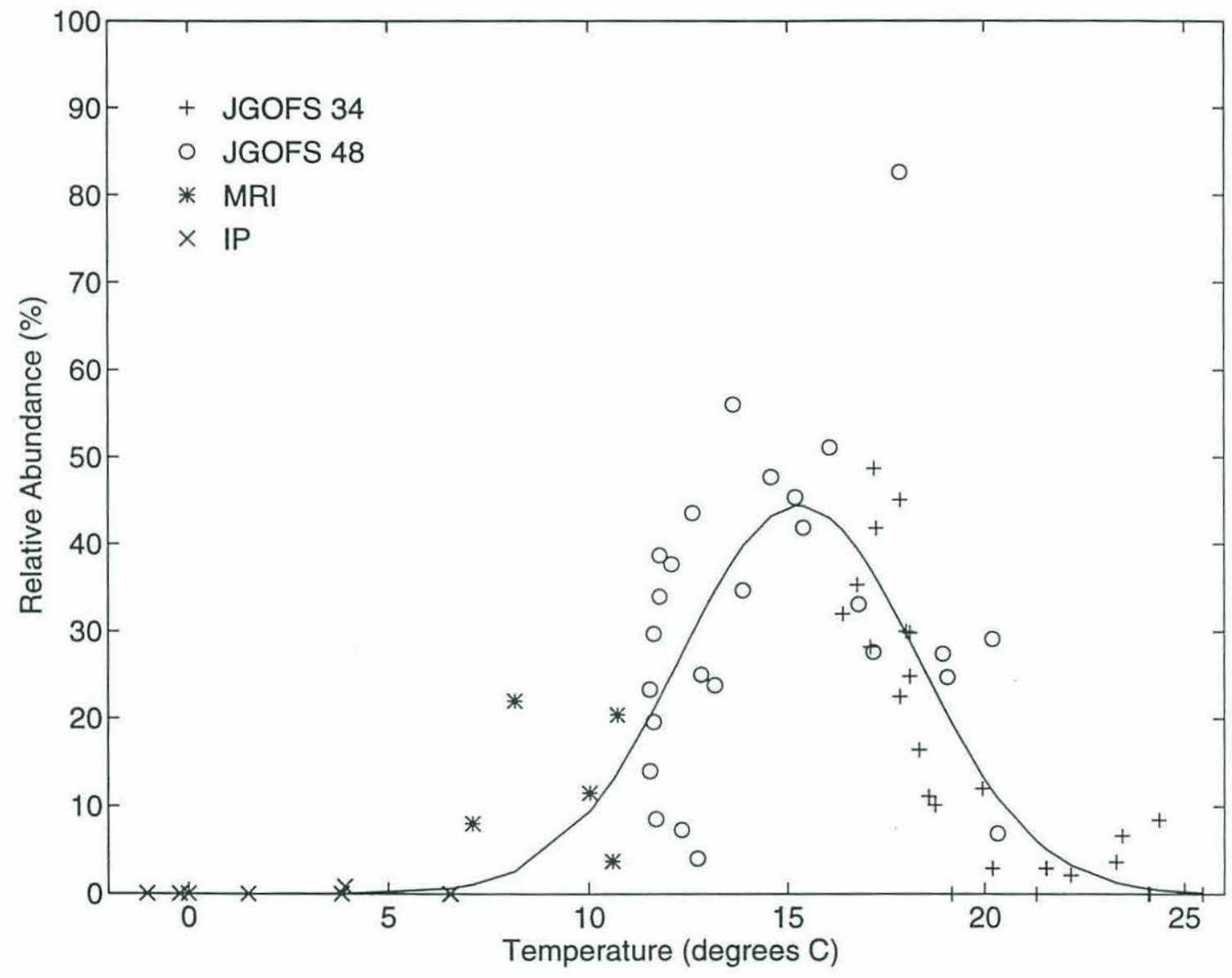

Figure 20. The relative abundance (in \%) of G. bulloides in the total flux is plotted against SST for samples from all four trap locations. A least squares Gaussian curve is fitted to this data with a mean of 15.3 and a standard deviation of 3 . 


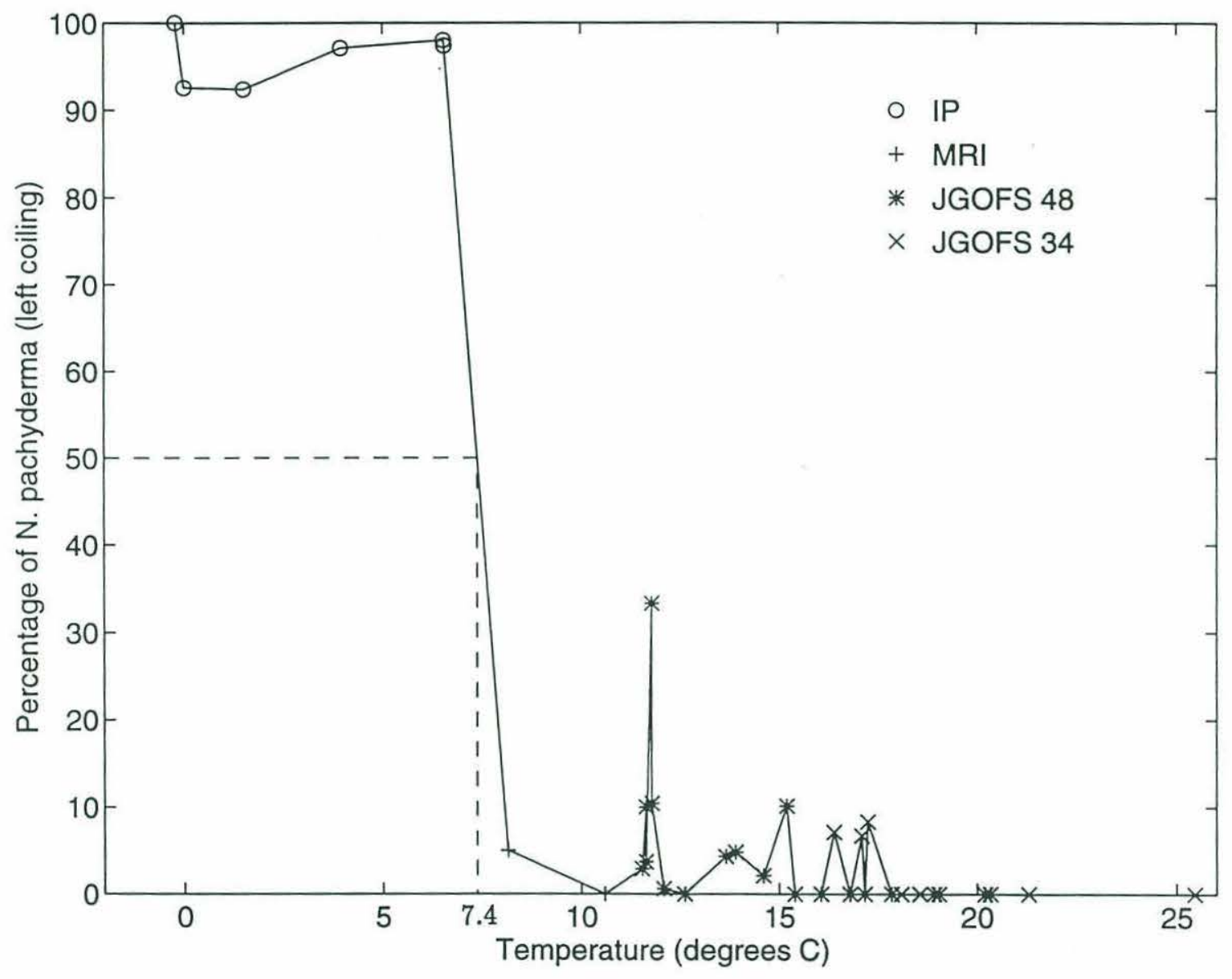

Figure 21. The percentage of left coiling N. pachyderma in total N. pachyderma is plotted against SST for samples from all four trap locations. Samples with a total $N$. pachyderma flux of less than $10 \mathrm{~m}^{-2}$ day -1 were excluded. The reversal in dominance between right and left coiling forms occurs at $50 \%$ (left coiling) at a SST of $\sim 7.4^{\circ}$. 
occurs at a SST of $\sim 7.4^{\circ} \mathrm{C}$ and designates the reversal in dominance between the two forms. This compares well with the $7.2^{\circ} \mathrm{C}$ isotherm used by Bé and Hamlin (1967), but unfortunately, the shift in dominance could not be documented within one trap location, which would have increased the reliability of this temperature estimate.

The preferred depth habitat of $N$. pachyderma is an important factor in considering the ecology of this species and its response to seasonal temperature changes (Reynolds and Thunell, 1986). N. pachyderma (right coiling) is the dominant species during the summer at JGOFS 48 (Figure 8a) which might seem incompatible with the cold water nature of this species. The shallow surface waters above the thermocline are generally nutrient depleted during the late summer because of the strong thermal stratification (Figure 14). Food availability (phytoplankton) in the shallow photic zone is thus reduced, thereby restricting the production of shallow spinose species such as $G$. bulloides. N. pachyderma, however, is a nonspinose, symbiont barren species that prefers depths at or below the thermocline in the region of the deep chlorophyll maximum (DCM) (Bé, 1977; Thunell and Reynolds, 1984; Reynolds and Thunell, 1986). N. pachyderma is also capable of migrating vertically in order to maintain a preferred temperature habitat of $\sim 11-14^{\circ} \mathrm{C}$ (Thunell and Sautter, 1992). Previous studies (Fairbanks and Wiebe (1980); Fairbanks et al., 1980) have demonstrated that peak abundances of several nonspinose foraminiferal species are associated with the DCM in the North Atlantic during periods of intense stratification in the upper water column. Joint et al. (1993) detected a subsurface chlorophyll maximum at the thermocline near $47^{\circ} \mathrm{N} 20^{\circ} \mathrm{W}$ in May and July of 1989 during the NABE. Higher nutrient and productivity levels at the DCM are exploited by deeper dwelling species like $N$. pachyderma, enabling it to remain at significant levels of abundance (Figure 6b) throughout the summer months at JGOFS 48. G. scitula, another deep nonspinose species (Bé, 1977), also exhibits significant flux increases (Figure 6e) during the summer season.

A secondary peak in production of $N$. pachyderma (right coiling) in August (Figure $6 \mathrm{~b})$ at JGOFS 48 coincides with a period of cyclonic eddy activity in this region. The upwelling associated with the eddy field results in the advection of cold nutrient-rich 
waters into the upper water column, stimulating increased phytoplankton production at the DCM. The fluxes of organic carbon (shallow and middle trap) and biogenic silica (shallow trap) more than double at JGOFS 48 during this period (Honjo and Manganini, 1992, 1993), indicating increased primary productivity coincident with the mesoscale eddy activity. The larger food supply enhances the production of deep cool-water foraminifera, which are dominated by $N$. pachyderma (right coiling) at JGOFS 48. The diet of $N$. pachyderma, like most non-spinose species, consists almost exclusively of phytoplankton, commonly diatoms (Hemleben et al., 1989). The flux results at JGOFS 48 are consistent with previous studies in the Panama Basin (Thunell et al., 1983; Thunell and Reynolds, 1984; Bé et al., 1985) and in the San Pedro Basin (Thunell and Sautter, 1992) showing sharp increases in N. pachyderma abundance with shoaling of the thermocline during upwelling. The flux increase of N. pachyderma during the summer at JGOFS 48 is a further indication of the rapid response of foraminiferal production to hydrographic changes induced by mesoscale variability.

\section{CONCLUSION}

This work has demonstrated the viability of using satellite-derived SST data for studying the seasonality of planktonic foraminiferal flux to the deep ocean. Satellite observations provide a reliable method of acquiring synchronous SST data on an ocean-wide scale. The resolution of the MCSST data set is also sufficient for detecting significant variations in mesoscale circulation fields in the North Atlantic that can strongly impact local hydrographic conditions. The thermal structure of the upper water column controls foraminiferal production by regulating levels of phytoplankton production and by directly influencing the preferred temperature habitats of species in the community. The most important physical processes affecting hydrographic conditions above the four sediment traps are the seasonal development and decay of the thermocline and the local upwelling within cyclonic eddies generated from meandering current systems.

The flux data in this study show that the timing of maximum foraminiferal pro- 
duction at each trap location coincides with the northward progression of the spring bloom in the North Atlantic. The proliferation of phytoplankton that follows the seasonal development of the thermocline directly increases the food supply for planktonic foraminifera. The positive correlation of foraminiferal production in this study with the seasonal pattern of oceanic fertility in the North Atlantic suggests that grazing by foraminifera intensifies simultaneously with increasing primary production.

The highest foraminiferal production recorded in this study occurs during the spring bloom at JGOFS 48 which is under the influence of high mesoscale variability generated near the Polar Front. AVHRR imagery confirms the presence of a mesoscale eddy field concurrent with spring bloom development in this region. Local upwelling, associated with the cyclonic circulation, resupplies nutrients in surface waters to further enhance biological production at JGOFS 48. Hence, mesoscale eddy activity may be considered a general condition for the particularly strong development of the spring bloom in this part of the North Atlantic. There is substantially less foraminiferal flux at JGOFS 34 during the bloom period because it is located near the perimeter of the North Central waters which are far less productive than surface waters near the Polar Front.

Secondary peaks in foraminiferal production at both JGOFS stations are also associated with mesoscale eddy activity caused by frontal instabilities in the open ocean. The upwelling associated with cyclonic eddies appears to be an effective mechanism in the North Atlantic for increasing the flux of foraminiferal tests to the sea floor. The preferred production of individual foraminiferal species during periods of eddy-induced upwelling, however, may depend on the vertical distribution of chlorophyll in the water column. The production of N. pachyderma (right coiling) sharply increases during summer upwelling at JGOFS 48 because of its association with a pronounced DCM. The advection of colder nutrient-rich waters into the mixed layer during upwelling increases the food supply at the DCM which preferentially benefits the deeper dwelling nonspinose foraminifera like $N$. pachyderma. Shallower spinose species may dominate the foraminiferal assemblage in upwelling zones where prior chlorophyll concentrations were relatively constant throughout the euphotic 
zone. Further study is needed, however, to better understand the effects of eddy circulation on biological processes and faunal composition in the upper water column.

Sea surface temperature is an important variable controlling seasonal variations in the relative abundance of planktonic foraminiferal species. The distinct seasonal succession of planktonic species at both JGOFS sites appears to be related to the various temperature habitats of different species. The seasonal semiannual shift in species dominance between $G$. ruber and G. bulloides at JGOFS 34 occurs at $\sim 18.5^{\circ} \mathrm{C}$, providing strong evidence supporting a dependence of foraminifera on preferred temperature ranges. The latitudinal range of species distributions in this study is also the result of the individual tolerance of species to warm or cold temperatures. The species assemblages collected at each of the four trap locations correlate well with previous work on the faunal zonation of the North Atlantic. There is a predictable decrease in both the number and diversity of planktonic species as one moves northward from the Subtropical zone (JGOFS 34) to the Arctic zone (IP). The majority of species prefer warmer temperature conditions, and only a few species (e.g. G. quinqueloba and $N$. pachyderma) are adapted to extreme subarctic and arctic temperatures.

The pronounced seasonality of planktonic foraminiferal flux is incorporated into the composite sedimentary record and should be an important aspect of paleoceanographic reconstruction. Because temperature is an important factor regulating the distribution of foraminiferal species, the relative abundance of individual species can be used to characterize the faunal composition of fossil assemblages and thus aid in the estimation of paleotemperatures. Tolerance limits for G. ruber, G. bulloides, and N. pachyderma have been estimated from our data, but the utility of these limits and other ecological inferences for paleoceanographic purposes should be further studied in other oceanographic settings. The extent of interannual variations is another important question in paleoceanography that could be addressed by future projects of longer duration. The thermal habitats of individual species may not be entirely consistent throughout the world's oceans (Cifelli, 1971), indicating that the utility of this type of data may be specific to particular ocean basins. 


\section{REFERENCES}

Anderson, O. R., Spindler, M., Bé, A. W. H., and Hemleben, Ch., 1979, Trophic activity of planktonic foraminifera: Journal of the Marine Biological Association of the United Kingdom, v. 59, p. 791-799.

Bé, A. W. H., 1977, An ecological, zoogeographic and taxonomic review of Recent planktonic foraminifera, in Ramsay, A. T. S. (ed.), Oceanic Micropaleontology, Volume 1: Academic Press, London, p. 1-100.

Bé, A. W. H. and Hamlin, W. H., 1967, Ecology of Recent planktonic foraminifera. Part 3. Distribution in the North Atlantic during the summer of 1962: Micropaleontology, v. 13, p. 87-106.

Bé, A. W. H. and Tolderlund D. S., 1971, Distribution and ecology of living planktonic foraminifera in surface waters of the Atlantic and Indian oceans, in Funnell, B. M. and Riedel, W. R. (eds.), Micropaleontology of Oceans: Cambridge University Press, London, p. 105-149.

Bé, A. W. H., Bishop, J. K. B., Sverdlove, M. S., and Gardner, W. D., 1985, Standing stock, vertical distribution and flux of planktonic foraminifera in the Panama Basin: Marine Micropaleontology, v. 9, p. 307-333.

Bé, A. W. H., Caron, D. A., and Anderson, O. R., 1981, Effects of feeding frequency on life processes of the planktonic foraminifer Globigerinoides sacculifer in laboratory culture: Journal of the Marine Biological Association of the United Kingdom, v. 61, p. 257-277.

Bé, A. W. H., Hemleben, Ch., Anderson, O. R., Spindler, M., Hacunda, J., and Tuntivate-Choy, S., 1977, Laboratory and field observations of living planktonic foraminifera: Micropaleontology, v. 23, p. 155-179.

Berger, W. H., 1971, Sedimentation of planktonic foraminifera: Marine Geology, v. 11, p. 325-358.

Berger, W. H. and Soutar, A., 1967, Planktonic foraminifera: Field experiment on production rate: Science, v. 156, p. 1495-1497.

Bernstein, R. L., 1984, Satellite sea surface temperature determination from microwave and infrared radiometry, in Gautier, C. and Fieux, M (eds.), Large-Scale Oceanographic Experiments and Satellites: D. Reidel Publishing, Dordrecht, p. 87-98.

Bijma, J., Faber, W. W., Jr., and Hemleben, Ch., 1990, Temperature and salinity limits for growth and survival of some planktonic foraminifers in laboratory cultures: Journal of Foraminiferal Research, v. 20, p. 95-116.

Cifelli, R., 1971, On the temperature relationships of planktonic foraminifera: Journal of Foraminiferal Research, v. 1, p. 170-177.

Curry, W. B., Ostermann, D. R., Guptha, M. V. S., and Ittekkot, V., 1992, Foraminiferal production and monsoonal upwelling in the Arabian Sea: evidence from sediment traps, in Summerhayes, C. P., Prell, W. L., and Emeis, K. C. (eds.), Upwelling Systems: Evolution Since the Early Miocene: Geological Society Special Publication No. 64, p. 93-106. 
Curry, W. B., Thunell, R. C., and Honjo, S., 1983, Seasonal changes in the isotopic composition of planktonic foraminifera collected in Panama Basin sediment traps: Earth and Planetary Science Letters, v. 64, p. 33-43.

Deuser, W. G., 1986, Seasonal and interannual variations in deep-water particle fluxes in the Sargasso Sea and their relation to surface hydrography: Deep-Sea Research, v. 33 , p. $225-246$.

Deuser, W. G., 1987, Seasonal variations in isotopic composition and deep-water fluxes of the tests of perennially abundant planktonic foraminifera of the Sargasso Sea: Results from sediment-trap collections and their paleoceanographic significance: Journal of Foraminiferal Research, v. 17, p. 14-27.

Deuser, W. G., Ross, E. H., Hemleben, Ch., and Spindler, M., 1981, Seasonal changes in species composition, numbers, mass, size, and isotopic composition of planktonic foraminifera settling into the deep Sargasso Sea: Palaeogeography, Palaeoclimatology, Palaeoecology, v. 33, p. 103-127.

Dietrich, G., Kalle, K., Krauss, W., and Siedler, G., 1980, General Oceanography: John Wiley, New York, 626 pp.

Ducklow, H. W., 1989, Joint Global Ocean Flux Study: The North Atlantic Bloom Experiment: Oceanography Magazine, v. 2, p. 4-8.

Esaias, W. E., Feldman, G. C., McClain, C. R., and Elrod, J. A., 1986, Monthly satellite-derived phytoplankton pigment distribution for the North Atlantic Ocean basin: EOS, v. 67, p. 835-837.

Fairbanks, R. G. and Wiebe, P. H., 1980, Foraminifera and chlorophyll maximum: Vertical distribution, seasonal succession, and paleoceanographic significance: Science, v. 209, p. 1524-1526.

Fairbanks, R. G., Sverdlove, M., Free, R., Wiebe, P. H., and Bé, A. W. H., 1982, Vertical distribution and isotopic fractionation of living planktonic foraminifera from the Panama Basin: Nature, v. 298, p. 841-844.

Fairbanks, R. G., Wiebe, P. H., and Bé, A. W. H., 1980, Vertical distribution and isotopic composition of living planktonic foraminifera in the western North Atlantic: Science, v. 207, p. 61-63.

Gardner, W. D., Walsh, I. D., and Richardson, M. J., 1993, Biophysical forcing of particle production and distribution during a spring bloom in the North Atlantic: Deep-Sea Research II, v. 40, p. 171-195.

Garside, C. and Garside, J. C., 1993, The "f-ratio" on $20^{\circ} \mathrm{W}$ during the North Atlantic Bloom Experiment: Deep-Sea Research II, v. 40, p. 75-90.

Gould, W. J., 1985, Physical oceanography of the Azores Front: Progress in Oceanography, v. 14, p. 167-190.

Halpern, D., Knauss, W., Brown, O., and Wentz, F., 1992, An Atlas of Monthly Mean Distributions of SSMI Surface Wind Speed, ARGOS Buoy Drift, AVHRR/2 Sea Surface Temperature, and ECMWF Surface Wind Components During 1989: NASA JPL Publication 92-17, 112 pp.

Hemleben, Ch., Spindler, M., and Anderson, O. R., 1989, Modern Planktonic Foraminifera: Springer-Verlag, New York, 363 pp.

Honjo, S., 1978, Sedimentation of materials in the Sargasso Sea at a $5367 \mathrm{~m}$ deep station: Journal of Marine Research, v. 36, p. 469-492. 
Honjo, S. and Doherty, K. W., 1988, Large aperture time-series sediment traps; design objectives, construction and application: Deep-Sea Research, v. 35, p. 133-149.

Honjo, S. and Manganini, S. J., 1992, Biogenic Particle fluxes at the $34^{\circ} \mathrm{N} 21^{\circ} \mathrm{W}$

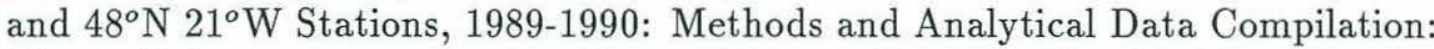
Woods Hole Oceanographic Institution Technical Report, WHOI-92-15, 77 pp.

Honjo, S. and Manganini, S. J., 1993, Annual biogenic particle fluxes to the interior of the North Atlantic Ocean; studied at $34^{\circ} \mathrm{N} 21^{\circ} \mathrm{W}$ and $48^{\circ} \mathrm{N} 21^{\circ} \mathrm{W}$ : Deep-Sea Research II, v. 40, p. 587-607.

Honjo, S., Connell, J. F., and Sachs, P. L., 1980, Deep-ocean sediment trap; design and function of PARFLUX Mark II: Deep-Sea Research, v. 27, p. 745-753.

Honjo, S., Manganini, S. J., and Cole, J. J., 1982, Sedimentation of biogenic matter in the deep ocean: Deep-Sea Research, v. 29, p. 609-625.

Howe, M. R. and Tait, R. I., 1967, A subsurface cold-core cyclonic eddy: Deep-Sea Research, v. 14, p. 373-378.

Joint, I., Pomroy, A., Savidge, G., and Boyd, P., 1993, Size-fractionated primary productivity in the northeast Atlantic in May-July 1989: Deep-Sea Research II, v. 40, p. $423-440$.

Käse, R. H. and Siedler, G., 1982, Meandering of the subtropical front south-east of the Azores: Nature, v. 300, p. 245-246.

Käse, R. H., Zenk, W., Sanford, T. B., and Hiller, W., 1985, Currents, fronts and eddy fluxes in the Canary Basin: Progress in Oceanography, v. 14, p. 231-257.

Krauss, W., 1986, The North Atlantic Current: Journal of Geophysical Research, v. 91, p. 5061-5074.

Krauss, W. and Böning, C. W., 1987, Lagrangian properties of eddy fields in the northern North Atlantic as deduced from satellite-tracked buoys: Journal of Marine Research, v. 45, p. 259-291.

Krauss, W. and Käse, R. H., 1984, Mean circulation and eddy kinetic energy in the eastern North Atlantic: Journal of Geophysical Research, v. 89, p. 3407-3415.

Krauss, W. and Meincke, J., 1982, Drifting buoy trajectories in the North Atlantic Current: Nature, v. 296, p. 737-740.

Krauss, W., Döscher, R., Lehmann, A., and Viehoff, T., 1990a, On eddy scales in the eastern and northern North Atlantic Ocean as a function of latitude: Journal of Geophysical Research, v. 95, p. 18049-18056.

Krauss, W., Käse, R. H., and Hinrichsen, H.-H., 1990b, The branching of the Gulf Stream southeast of the Grand Banks: Journal of Geophysical Research, v. 95, p. 13089-13103.

Kupferman, S. L., Becker, G. A., Simmons, W. F., Schauer, U., Marietta, M. G., and Nies, H., 1986, An intense cold core eddy in the North-East Atlantic: Nature, v. 319 , p. $474-477$.

Lochte, K. and Pfannkuche, O., 1987, Cyclonic cold-core eddy in the eastern North Atlantic. II. Nutrients, phytoplankton and bacterioplankton: Marine Ecology Progress Series, v. 39, p. 153-164.

Lochte, K., Ducklow, H. W., Fasham, M. J. R., and Stienen, C., 1993, Plankton succession and carbon cycling at $47^{\circ} \mathrm{N} 20^{\circ} \mathrm{W}$ during the JGOFS North Atlantic Bloom Experiment: Deep-Sea Research II, v. 40: 91-114. 
Marra, J. and Ho, C., 1993, Initiation of the spring bloom in the northeast Atlantic $\left(47^{\circ} \mathrm{N}, 20^{\circ} \mathrm{W}\right)$ : a numerical simulation: Deep-Sea Research II, v. 40, p. 55-73.

McClain, E. P., Pichel, W. G., and Walton, C. C., 1985, Comparative performance of AVHRR-based multichannel sea surface temperatures: Journal of Geophysical Research, v. 90, p. 11587-11601.

Mittelstaedt, E., 1987, Cyclonic cold-core eddy in the eastern North Atlantic. I. Physical description: Marine Ecology Progress Series, v. 39, p. 145-152.

Parsons, T. R., Takahashi, M., and Hargrave, B., 1984, Biological Oceanographic Processes: Pergamon Press, Oxford, 330 pp.

Reynolds, L. A. and Thunell, R. C., 1985, Seasonal succession of planktonic foraminifera in the subpolar North Pacific: Journal of Foraminiferal Research, v. 15, p. 282-301.

Reynolds, L. A. and Thunell, R. C., 1986, Seasonal production and morphologic variation of Neogloboquadrina pachyderma (Ehrenberg) in the northeast Pacific: Micropaleontology, v. 32, p. 1-18.

Robinson, A. R., McGillicuddy, D. J., Calman, J., Ducklow, H. W., Fasham, M. J. R., Hoge, F. E., Leslie, W. G., McCarthy, J. J., Podewski, S., Porter, D. L., Saure, G., and Yoder, J. A., 1993, Mesoscale and upper ocean variabilities during the 1989 JGOFS bloom study: Deep-Sea Research II, v. 40, p. 9-35.

Sautter, L. R. and Thunell, R. C., 1989, Seasonal succession of planktonic foraminifera: Results from a four-year time-series sediment trap experiment in the northeast Pacific: Journal of Foraminiferal Research, v. 19, p. 253-267.

Sautter, L. R. and Thunell, R. C., 1991, Planktonic foraminiferal response to upwelling and seasonal hydrographic conditions: sediment trap results from San Pedro Basin, Southern California Bight: Journal of Foraminiferal Research, v. 21, p. 347-363.

Sieracki, M. E., Verity, P. G., and Stoecker, D. K., 1993, Plankton community response to sequential silicate and nitrate depletion during the 1989 North Atlantic spring bloom: Deep-Sea Research II, v. 40, p. 213-225.

Smith, E., 1992, A User's Guide to the NOAA Advanced Very High Resolution Radiometer Multichannel Sea Surface Temperature Data Set: NASA - Jet Propulsion Laboratory, $22 \mathrm{pp}$.

Spindler, M., Hemleben, Ch., Salomons, J. B., and Smit, L. P., 1984, Feeding behavior of some planktonic foraminifers in laboratory cultures: Journal of Foraminiferal Research, v. 14, p. 237-249.

Takahashi, K. and Bé, A. W. H., 1984, Planktonic foraminifera: factors controlling sinking speeds: Deep-Sea Research, v. 31, p. 1477-1500.

Thunell, R. C. and Honjo, S., 1987, Seasonal and interannual changes in planktonic foraminiferal production in the North Pacific: Nature, v. 328, p. 335-337.

Thunell, R. C. and Reynolds, L. A., 1984, Sedimentation of planktonic foraminifera: Seasonal changes in species flux in the Panama Basin: Micropaleontology, v. 30, p. 243-262. 
Thunell, R. C. and Sautter, L. R., 1992, Planktonic foraminiferal faunal and stable isotopic indices of upwelling: a sediment trap study in the San Pedro Basin, Southern California Bight, in Summerhayes, C. P., Prell, W. L., and Emeis, K. C. (eds.), Upwelling Systems: Evolution Since the Early Miocene: Geological Society Special Publication No. 64, p. 77-91.

Thunell, R. C., Curry, W. B., and Honjo, S., 1983, Seasonal variation in the flux of planktonic foraminifera: time series sediment trap results from the Panama Basin: Earth and Planetary Science Letters, v. 64, p. 44-55.

Tolderlund, D. S. and Be, A. W. H., 1971, Seasonal distribution of planktonic foraminifera in the western North Atlantic: Micropaleontology, v. 17, p. 297-329.

Valiela, I., 1984, Marine Ecological Processes: Springer-Verlag, New York, 546 pp.

Viehoff, T. and Fischer, J., 1988, Satellite sea surface temperature at the North Atlantic Polar Front related to high resolution towed Conductivity - TemperatureDepth data: Journal of Geophysical Research, v. 93, p. 15551-15560.

Vilks, G., 1973, A study of Globorotalia pachyderma (Ehrenberg) = Globigerina pachyderma (Ehrenberg) in the Canadian Arctic: Doctoral Thesis, Dalhousie University.

Yentsch, C. S., 1990, Estimates of "new production" in the mid-North Atlantic: Journal of Plankton Research, v. 12, p. 717-734.

Yoder, J. A., Aiken, J., Swift, R. N., Hoge, F. E., and Stegmann, P. M., 1993, Spatial variability in near-surface chlorophyll $a$ fluorescence measured by the Airborne Oceanographic Lidar (AOL): Deep-Sea Research II, v. 40, p. 37-53. 
APPENDIX I: Planktonic foraminiferal fluxes and relative abundances of species at the JGOFS 34 , JGOFS 48 , MRI, and IP sediment trap locations. The tables include data for all species that account for at least $1 \%$ of the overall total flux at a particular station. Relative abundances are not calculated for sediment trap samples with a total flux of less than $10 \mathrm{~m}^{-2} \mathrm{day}^{-1}$ for the sampling period. These data have not been time-corrected to account for life span and settling time but the appropriate correction factors applied in this study are included in the tables. 
JGOFS 34

\begin{tabular}{|c|c|c|c|c|c|c|}
\hline \multirow{2}{*}{$\begin{array}{c}\text { JGOFS } \\
\text { cup }\end{array}$} & \multirow{2}{*}{$\begin{array}{r}\text { Date cup opens } \\
\text { (1989-1990) } \\
\text { (JD) }\end{array}$} & \multirow{2}{*}{$\begin{array}{c}\text { Time } \\
\text { correction } \\
\text { factor (days) }\end{array}$} & G. bulloides & G. ruber & G. glutinata & G. scitula \\
\hline & & & Flux (\%) & Flux (\%) & Flux (\%) & Flux (\%) \\
\hline I-1 & Apr 03 (459) & 27 & $51(24.8)$ & $51 \quad(24.8)$ & $26(12.6)$ & $\begin{array}{ll}0 & (0.0)\end{array}$ \\
\hline $\mathrm{I}-2$ & Apr 08 (464) & 27 & $228(22.5)$ & 219 & $292(28.9)$ & $27 \quad(2.7)$ \\
\hline I-3 & Apr 22 (478) & 27 & $591(29.8)$ & $242(12.2)$ & $242(12.2)$ & $299(15.1)$ \\
\hline I-4 & May 06 (492) & 27 & $242(30.0)$ & 206 & $170(21.1)$ & $63(7.8)$ \\
\hline I-5 & May $20(506)$ & 27 & 73 (11.1) & 244 & $37 \quad(5.6)$ & $52(7.9)$ \\
\hline I-6 & Jun 06 (523) & 27 & $\begin{array}{ll}0 & (0.0)\end{array}$ & 72 (61.5) & $18(15.4)$ & $9(7.7)$ \\
\hline I-7 & Jun 20 (537) & 27 & $9 \quad(2.9)$ & $90 \quad(28.6)$ & $18 \quad(5.7)$ & $27 \quad(8.6)$ \\
\hline I-8 & Jul $04 \quad(551)$ & 27 & $\begin{array}{ll}0 & (0.0)\end{array}$ & $45 \quad(20.0)$ & $\begin{array}{ll}0 & (0.0)\end{array}$ & $18(8.0)$ \\
\hline I-9 & Jul $18 \quad$ (565) & 27 & $\begin{array}{ll}0 & (0.0)\end{array}$ & $27 \quad(75.0)$ & $\begin{array}{ll}0 & (0.0)\end{array}$ & $9(25.0)$ \\
\hline I- 10 & Aug 01 (579) & 27 & $18 \quad(8.4)$ & 134 & $\begin{array}{ll}0 & (0.0)\end{array}$ & $9(4.2)$ \\
\hline I-11 & Aug 15 (593) & 27 & $\begin{array}{ll}0 & (0.0)\end{array}$ & $27(100.0)$ & $\begin{array}{ll}0 & (0.0)\end{array}$ & $0(0.0)$ \\
\hline I-12 & Aug 29 (607) & 27 & 0 & 0 & 0 & 0 \\
\hline I-13 & Sep 12 (621) & 27 & $0 \quad(0.0)$ & $99 \quad(78.6)$ & 9 (7.1) & $0(0.0)$ \\
\hline II-1 & Oct 16 (655) & 27 & $5 \quad(6.6)$ & 34 (44.7) & $\begin{array}{ll}6 & (7.9)\end{array}$ & $4 \quad(5.3)$ \\
\hline II-2 & Oct 30 (669) & 27 & $4 \quad(3.6)$ & $54 \quad(48.2)$ & $14(12.5)$ & 13 (11.6) \\
\hline II-3 & Nov 13 (683) & 27 & $2 \quad(2.1)$ & $63(65.6)$ & $13(13.5)$ & $\begin{array}{ll}4 & (4.2)\end{array}$ \\
\hline II-4 & Nov 27 (697) & 27 & $\begin{array}{ll}6 & (2.9)\end{array}$ & 109 (52.7) & $26(12.6)$ & 10 \\
\hline II-5 & Dec 11 (711) & 27 & $14(12.0)$ & $40 \quad(34.2)$ & $20(17.1)$ & $0(0.0)$ \\
\hline II-6 & $\operatorname{Dec} 25$ (725) & 27 & $40(10.1)$ & $72(18.2)$ & 14 (3.5) & $3(0.8)$ \\
\hline II-7 & Jan 08 & 27 & $88(16.4)$ & $55(10.2)$ & 34 (6.3) & $8(1.5)$ \\
\hline II- 8 & Jan 22 & 27 & $280(45.1)$ & $33 \quad(5.3)$ & $63(10.1)$ & $6(1.0)$ \\
\hline II-9 & Feb 05 (767) & 27 & $425(48.7)$ & $41 \quad$ (4.7) & $149(17.1)$ & 37 (4.2) \\
\hline II-10 & Feb 19 (781) & 27 & $222(41.8)$ & $39 \quad(7.3)$ & $54(10.2)$ & $17 \quad(3.2)$ \\
\hline II-11 & Mar 05 (795) & 27 & $127(28.2)$ & $36 \quad(8.0)$ & $53(11.8)$ & $29(6.4)$ \\
\hline II-12 & Mar 19 (809) & 27 & $155(32.0)$ & $26 \quad(5.4)$ & $34(7.0)$ & $90(18.6)$ \\
\hline \multirow[t]{2}{*}{ II-13 } & Apr 02 (823) & 27 & $79(35.3)$ & $17 \quad(7.6)$ & $29(12.9)$ & $50(22.3)$ \\
\hline & Totals & - & $2659(25.4)$ & 2075 (19.8) & 1321 (12.6) & 784 (7.5) \\
\hline
\end{tabular}


JGOFS 34 (Extended)

\begin{tabular}{|c|c|c|c|c|c|c|}
\hline \multirow[t]{2}{*}{$\begin{array}{l}\text { JGOFS } \\
\text { cup }\end{array}$} & G. inflata & G. sacculifer & G. parkeri & G. hirsuta & $\begin{array}{l}\text { G. truncatulinoides } \\
\text { (left) }\end{array}$ & \multirow{2}{*}{$\begin{array}{l}\text { G. tenellus } \\
\text { Flux (\%) }\end{array}$} \\
\hline & Flux (\%) & Flux (\%) & Flux (\%) & Flux (\%) & Flux (\%) & \\
\hline $\mathrm{I}-1$ & $26(12.6)$ & $\begin{array}{l}0 \\
0\end{array}(0.0)$ & $0(0.0)$ & $52(25.2)$ & $0 \quad(0.0)$ & $0(0.0)$ \\
\hline $\mathrm{I}-2$ & 37 (3.7) & $55 \quad(5.4)$ & $0(0.0)$ & $18 \quad(1.8)$ & $0(0.0)$ & 73 (7.2) \\
\hline I-3 & 72 (3.6) & $108(5.4)$ & $0(0.0)$ & $188(9.5)$ & $27(1.4)$ & $45(2.3)$ \\
\hline I-4 & $9(1.1)$ & $45 \quad(5.6)$ & $0(0.0)$ & $9(1.1)$ & $9(1.1)$ & $27(3.3)$ \\
\hline I-5 & 45 (6.8) & $51 \quad(7.8)$ & $0(0.0)$ & $22(3.3)$ & $22(3.3)$ & $30(4.6)$ \\
\hline I-6 & $0 \quad(0.0)$ & $\begin{array}{ll}9 & (7.7)\end{array}$ & $0(0.0)$ & $0(0.0)$ & $0(0.0)$ & $0(0.0)$ \\
\hline I-7 & $36(11.4)$ & $90(28.6)$ & $0(0.0)$ & $0 \quad(0.0)$ & $0 \quad(0.0)$ & $18(5.7)$ \\
\hline I-8 & $63(28.0)$ & $27(12.0)$ & $0(0.0)$ & $18 \quad(8.0)$ & $9(4.0)$ & $9(4.0)$ \\
\hline I-9 & $0 \quad(0.0)$ & $0(0.0)$ & $0(0.0)$ & $0(0.0)$ & $0(0.0)$ & $0(0.0)$ \\
\hline I-10 & $18(8.4)$ & $0 \quad(0.0)$ & $0(0.0)$ & $0(0.0)$ & $0(0.0)$ & $18(8.4)$ \\
\hline I-11 & $0 \quad(0.0)$ & $0 \quad(0.0)$ & $0 \quad(0.0)$ & $0(0.0)$ & $0(0.0)$ & $0(0.0)$ \\
\hline I-12 & 0 & 0 & 0 & 0 & 0 & 0 \\
\hline I-13 & $0 \quad(0.0)$ & $0(0.0)$ & $0(0.0)$ & $0(0.0)$ & $0(0.0)$ & $0(0.0)$ \\
\hline II-1 & $0 \quad(0.0)$ & $3(3.9)$ & $0 \quad(0.0)$ & $0(0.0)$ & $0(0.0)$ & $9(7.9)$ \\
\hline II-2 & $\begin{array}{ll}0 & (0.0)\end{array}$ & $3(2.7)$ & $0(0.0)$ & $0(0.0)$ & $0(0.0)$ & $6(5.4)$ \\
\hline II-3 & $0 \quad(0.0)$ & $3(3.1)$ & $0(0.0)$ & $0(0.0)$ & $0(0.0)$ & $7(7.3)$ \\
\hline II-4 & $0 \quad(0.0)$ & $47(22.7)$ & $1(0.5)$ & $0(0.0)$ & $0(0.0)$ & $0(0.0)$ \\
\hline II-5 & $2(1.7)$ & $16(13.7)$ & $9(7.7)$ & $0(0.0)$ & $0(0.0)$ & $7(6.0)$ \\
\hline II-6 & $7 \quad(1.8)$ & $22(5.6)$ & $209(52.9)$ & $1(0.3)$ & $11(2.8)$ & $1(0.3)$ \\
\hline II-7 & 60 (11.2) & 14 (2.6) & $160(29.7)$ & $4(0.7)$ & $108(20.1)$ & $1(0.2)$ \\
\hline II-8 & $56(9.0)$ & $9(1.4)$ & $110(17.7)$ & $3(0.5)$ & $50(8.1)$ & $3(0.5)$ \\
\hline II-9 & $74 \quad(8.5)$ & $7(0.8)$ & $24 \quad(2.8)$ & $33(3.8)$ & $47(5.4)$ & $4(0.5)$ \\
\hline II-10 & 73 (13.7) & $12(2.3)$ & $1(0.2)$ & $58(10.9)$ & $33(6.2)$ & $1(0.2)$ \\
\hline II-11 & 57 (12.7) & $10(2.2)$ & $8(1.8)$ & $41 \quad(9.1)$ & $13(2.9)$ & $6(1.3)$ \\
\hline II-12 & $56(11.5)$ & $29(6.0)$ & $1(0.2)$ & $50(10.3)$ & $12(2.5)$ & $8(1.6)$ \\
\hline II-13 & $11(4.9)$ & $10(4.5)$ & $9(4.0)$ & $12(5.4)$ & $2(0.9)$ & $0(0.0)$ \\
\hline Totals & $702(6.7)$ & $570 \quad(5.4)$ & $532 \quad(5.1)$ & $509(4.9)$ & $343 \quad(3.3)$ & $273(2.6)$ \\
\hline
\end{tabular}




\section{JGOFS 34 (Extended)}

\begin{tabular}{|c|c|c|c|c|c|}
\hline \multirow[t]{2}{*}{$\begin{array}{l}\text { JGOFS } \\
\text { cup }\end{array}$} & G. aequilateralis & $\begin{array}{l}\text { N. pachyderma } \\
\text { (right) }\end{array}$ & G. calida & Other & \multirow[t]{2}{*}{ Total Flux } \\
\hline & Flux (\%) & Flux (\%) & Flux (\%) & Flux (\%) & \\
\hline I-1 & $0 \quad(0.0)$ & $0 \quad(0.0)$ & $0 \quad(0.0)$ & $0(0.0)$ & 206 \\
\hline $\mathrm{I}-2$ & $18(1.8)$ & 36 (3.6) & $9(0.9)$ & $0(0.0)$ & 1012 \\
\hline $\mathrm{I}-3$ & 72 (3.6) & $18 \quad(0.9)$ & $36(1.8)$ & $45 \quad(2.3)$ & 1985 \\
\hline I-4 & $18 \quad(2.2)$ & $0 \quad(0.0)$ & $9(1.1)$ & $0 \quad(0.0)$ & $807^{\circ}$ \\
\hline I-5 & $37(5.6)$ & $15 \quad(2.3)$ & $22(3.3)$ & $7(1.1)$ & 657 \\
\hline I-6 & $0 \quad(0.0)$ & $0 \quad(0.0)$ & $9(7.7)$ & $0 \quad(0.0)$ & 117 \\
\hline $\mathrm{I}-7$ & $9 \quad(2.9)$ & $0(0.0)$ & $18(5.7)$ & $0(0.0)$ & 315 \\
\hline I-8 & $18 \quad(8.0)$ & $18(8.0)$ & $0(0.0)$ & $0(0.0)$ & 225 \\
\hline I-9 & $0 \quad(0.0)$ & $0 \quad(0.0)$ & $0(0.0)$ & $0(0.0)$ & 36 \\
\hline I-10 & $18 \quad(8.4)$ & $0 \quad(0.0)$ & $0(0.0)$ & $0 \quad(0.0)$ & 215 \\
\hline I-11 & $0 \quad(0.0)$ & $0 \quad(0.0)$ & $0(0.0)$ & $0 \quad(0.0)$ & 27 \\
\hline I-12 & 0 & 9 & 0 & 0 & 9 \\
\hline I-13 & $0 \quad(0.0)$ & $18(14.3)$ & $0(0.0)$ & $0(0.0)$ & 126 \\
\hline II-1 & $3 \quad(3.9)$ & $0 \quad(0.0)$ & $0(0.0)$ & $12(15.8)$ & 76 \\
\hline II-2 & $3(2.7)$ & $0 \quad(0.0)$ & $0(0.0)$ & $15(13.4)$ & 112 \\
\hline II-3 & $0(0.0)$ & $1(1.0)$ & $0(0.0)$ & $3(3.1)$ & 96 \\
\hline II-4 & $6(2.9)$ & $0(0.0)$ & $0(0.0)$ & $2(1.0)$ & 207 \\
\hline II-5 & $1 \quad(0.9)$ & $0(0.0)$ & $0(0.0)$ & $8(6.8)$ & 117 \\
\hline II-6 & $13(3.3)$ & $0(0.0)$ & $0 \quad(0.0)$ & $2(0.5)$ & 395 \\
\hline II-7 & $4(0.7)$ & $0(0.0)$ & $0(0.0)$ & $2(0.4)$ & 538 \\
\hline II-8 & $1(0.2)$ & $0(0.0)$ & $0(0.0)$ & $7(1.1)$ & 621 \\
\hline II-9 & $3(0.3)$ & $0 \quad(0.0)$ & $0 \quad(0.0)$ & $28 \quad(3.2)$ & 872 \\
\hline II-10 & $2(0.4)$ & $11(2.1)$ & $0(0.0)$ & $8(1.5)$ & 531 \\
\hline II-11 & $1(0.2)$ & $56(12.4)$ & $0(0.0)$ & $13 \quad(2.9)$ & 450 \\
\hline II-12 & $1(0.2)$ & $13(2.7)$ & $0 \quad(0.0)$ & $10(2.1)$ & 485 \\
\hline II-13 & $1(0.4)$ & $1(0.4)$ & $0(0.0)$ & 3. (1.3) & 224 \\
\hline Totals & $229(2.2)$ & $196(1.9)$ & $103(1.0)$ & 165 (1.6) & 10461 \\
\hline
\end{tabular}


JGOFS 48

\begin{tabular}{|c|c|c|c|c|c|}
\hline $\begin{array}{l}\text { JGOFS } \\
\text { cup }\end{array}$ & $\begin{array}{l}\text { Date cup opens } \\
(1989-90)\end{array}$ & $\begin{array}{c}\text { Time } \\
\text { correction } \\
\text { factor (days) }\end{array}$ & G. bulloides & $\begin{array}{c}\text { N. pachyderma } \\
\text { (right) }\end{array}$ & G. glutinata \\
\hline & (JD) & & Flux (\%) & Flux (\%) & Flux (\%) \\
\hline I-1 & Apr 03 (459) & 27 & $126(38.7)$ & $50(15.3)$ & $75(23.0)$ \\
\hline $\mathrm{I}-2$ & Apr 08 (464) & 27 & $323(34.0)$ & $233(24.5)$ & $197(20.7)$ \\
\hline I-3 & Apr 22 (478) & 27 & $188(19.6)$ & $242(25.2)$ & $251(26.1)$ \\
\hline I-4 & May 06 (492) & 27 & $1541(37.7)$ & $1478(36.2)$ & $358 \quad(8.8)$ \\
\hline I-5 & May 20 (506) & 27 & $2243(43.6)$ & $1395(27.1)$ & $369 \quad(7.2)$ \\
\hline I-6 & Jun 06 (523) & 27 & $1263(56.0)$ & $403(17.9)$ & $125 \quad(5.5)$ \\
\hline I-7 & Jun 20 (537) & 27 & $744(47.7)$ & $412(26.4)$ & $27 \quad(1.7)$ \\
\hline I-8 & Jul 04 (551) & 27 & $224(45.4)$ & $161(32.7)$ & $0 \quad(0.0)$ \\
\hline I-9 & Jul 18 (565) & 27 & $99(27.6)$ & $170(47.4)$ & $0 \quad(0.0)$ \\
\hline I-10 & Aug 01 (579) & 27 & $179(27.4)$ & $251(38.4)$ & $0 \quad(0.0)$ \\
\hline I-11 & Aug 15 (593) & 27 & $81(29.1)$ & $134(48.2)$ & $18 \quad(6.5)$ \\
\hline I-12 & Aug 29 (607) & 27 & $63 \quad(6.9)$ & $762(83.3)$ & $9 \quad(1.0)$ \\
\hline$[-13$ & Sep $12(621)$ & 27 & $224(24.7)$ & $466(51.4)$ & $9 \quad(1.0)$ \\
\hline II-1 & Oct $16(655)$ & 27 & $199(82.6)$ & $11(4.6)$ & $10(4.1)$ \\
\hline II-2 & Oct 30 (669) & 27 & $39(33.1)$ & $26(22.0)$ & $4(3.4)$ \\
\hline II-3 & Nov 13 (683) & 27 & $114(51.1)$ & $61(27.4)$ & $7 \quad(3.1)$ \\
\hline II-4 & Nov 27 (697) & 32 & $72(41.9)$ & $24(14.0)$ & $3 \quad(1.7)$ \\
\hline II-5 & Dec 11 (711) & 32 & $33(34.7)$ & $20(21.1)$ & $9(9.5)$ \\
\hline II-6 & $\operatorname{Dec} 25(725)$ & 32 & $19(25.0)$ & $0 \quad(0.0)$ & $13(17.1)$ \\
\hline II-7 & Jan 08 (739) & 32 & $10(23.8)$ & $1 \quad(2.4)$ & $6(14.3)$ \\
\hline II-8 & $\operatorname{Jan} 22(753)$ & 32 & $4(4.0)$ & $1 \quad(1.0)$ & $41(41.0)$ \\
\hline II-9 & Feb 05 (767) & 32 & $3(7.3)$ & $0 \quad(0.0)$ & $24(58.5)$ \\
\hline II-10 & Feb 19 (781) & 32 & $9(8.5)$ & $1 \quad(0.9)$ & $36(34.0)$ \\
\hline II-11 & Mar 05 (795) & 32 & $15(14.0)$ & $0 \quad(0.0)$ & $17(15.9)$ \\
\hline II- 12 & Mar $19(809)$ & 32 & $210(29.7)$ & $206(29.2)$ & $76(10.8)$ \\
\hline \multirow[t]{2}{*}{ II-13 } & Apr 02 (823) & 32 & $769(23.3)$ & $1386(42.1)$ & $399(12.1)$ \\
\hline & Totals & & 8794 (36.3) & $7894(32.6)$ & $2083(8.6)$ \\
\hline
\end{tabular}




\section{JGOFS 48 (Extended)}

\begin{tabular}{|c|c|c|c|c|c|}
\hline \multirow{2}{*}{$\begin{array}{c}\text { JGOFS } \\
\text { cup }\end{array}$} & \multirow{2}{*}{$\frac{\text { G. inflata }}{\text { Flux (\%) }}$} & \multirow{2}{*}{$\frac{\text { G. scitula }}{\text { Flux (\%) }}$} & \multirow{2}{*}{$\frac{\text { G. quinqueloba }}{\text { Flux (\%) }}$} & \multirow{2}{*}{$\begin{array}{c}\text { Other } \\
\text { Flux (\%) }\end{array}$} & \multirow[b]{2}{*}{ Total Flux } \\
\hline & & & & & \\
\hline$I-1$ & $50(15.3)$ & $0 \quad(0.0)$ & $0 \quad(0.0)$ & $25 \quad(7.7)$ & 326 \\
\hline $\mathrm{I}-2$ & $99(10.4)$ & $0(0.0)$ & $0 \quad(0.0)$ & $99(10.4)$ & 951 \\
\hline $\mathrm{I}-3$ & $135(14.1)$ & $9(0.9)$ & $0(0.0)$ & $135(14.1)$ & 960 \\
\hline $\mathrm{I}-4$ & 322 (7.9) & $99 \quad(2.4)$ & $108 \quad(2.6)$ & $180 \quad(4.4)$ & 4086 \\
\hline I-5 & $103(2.0)$ & $340(6.6)$ & $502 \quad(9.8)$ & $192(3.7)$ & 5144 \\
\hline I-6 & $45 \quad(2.0)$ & $134 \quad(5.9)$ & $197(8.7)$ & $90 \quad(4.0)$ & 2257 \\
\hline I-7 & $0 \quad(0.0)$ & $90 \quad(5.8)$ & $152(9.7)$ & 135 (8.7) & 1560 \\
\hline I-8 & $9 \quad(1.8)$ & $45 \quad(9.1)$ & $18 \quad(3.7)$ & $36(7.3)$ & 493 \\
\hline I-9 & $\begin{array}{ll}0 & (0.0)\end{array}$ & $27 \quad(7.5)$ & $45(12.5)$ & $18 \quad(5.0)$ & 359 \\
\hline I-10 & $36 \quad(5.5)$ & $152(23.2)$ & $0(0.0)$ & $36(5.5)$ & 654 \\
\hline I-11 & $0 \quad(0.0)$ & $27 \quad(9.7)$ & $0(0.0)$ & $18 \quad(6.5)$ & 278 \\
\hline I-12 & $18 \quad(2.0)$ & $18 \quad(2.0)$ & $0(0.0)$ & $45 \quad(4.9)$ & 915 \\
\hline I-13 & $72 \quad(7.9)$ & $81 \quad(8.9)$ & $0(0.0)$ & $54 \quad(6.0)$ & 906 \\
\hline II-1 & $16(6.6)$ & $3(1.2)$ & $0(0.0)$ & $2(0.8)$ & 241 \\
\hline II-2 & $26(22.0)$ & $4(3.4)$ & $10(8.5)$ & $9 \quad(7.6)$ & 118 \\
\hline II-3 & $39(17.5)$ & $1(0.4)$ & $0(0.0)$ & $1 \quad(0.4)$ & 223 \\
\hline II-4 & $72(41.9)$ & $1(0.6)$ & $0(0.0)$ & $0 \quad(0.0)$ & 172 \\
\hline II-5 & $29(30.5)$ & $0(0.0)$ & $0(0.0)$ & $4 \quad(4.2)$ & 95 \\
\hline II-6 & $28(36.8)$ & $4(5.3)$ & $0(0.0)$ & $12(15.8)$ & 76 \\
\hline II-7 & $16(38.1)$ & $6(14.3)$ & $0(0.0)$ & $3(7.1)$ & 42 \\
\hline II-8 & $28(28.0)$ & $17(17.0)$ & $0(0.0)$ & $9(9.0)$ & 100 \\
\hline II-9 & $7(17.1)$ & $6(14.6)$ & $0(0.0)$ & $1(2.4)$ & 41 \\
\hline II-10 & $7(6.6)$ & $51(48.1)$ & $0(0.0)$ & $2(1.9)$ & 106 \\
\hline II-11 & $17(15.9)$ & $54(50.5)$ & $0(0.0)$ & $4(3.7)$ & 107 \\
\hline II-12 & $76(10.8)$ & $80(11.3)$ & $9(1.3)$ & $49 \quad(6.9)$ & 706 \\
\hline II-13 & $505(15.3)$ & $115(3.5)$ & $7(0.2)$ & 115 (3.5) & 3296 \\
\hline Totals & $1755(7.2)$ & $1364(5.6)$ & $1048(4.3)$ & $1274 \quad(5.3)$ & 24212 \\
\hline
\end{tabular}


MRI

\begin{tabular}{|c|c|c|c|c|c|c|c|c|c|}
\hline \multirow{2}{*}{$\begin{array}{l}\text { MRI } \\
\text { cup }\end{array}$} & \multirow{2}{*}{$\begin{array}{c}\text { Date cup } \\
\text { opens } \\
\text { (1988-1989) } \\
\text { (JD) }\end{array}$} & \multirow{2}{*}{$\begin{array}{l}\text { Time } \\
\text { correction } \\
\text { factor } \\
\text { (days) }\end{array}$} & \multirow{2}{*}{$\begin{array}{c}\text { G. } \\
\text { quinqueloba } \\
\overline{\text { Flux (\%) }}\end{array}$} & $\begin{array}{c}G . \\
\text { bulloides }\end{array}$ & \multirow{2}{*}{$\begin{array}{c}N . \\
\begin{array}{c}N a c h y d e r m a \\
\text { (right) }\end{array} \\
\frac{\text { Flux (\%) }}{}\end{array}$} & \multirow{2}{*}{$\begin{array}{c}\text { G. } \\
\text { glutinata }\end{array}$} & \multirow{2}{*}{$\begin{array}{c}G . \\
\text { sacculifer } \\
\text { Flux (\%) }\end{array}$} & \multirow{2}{*}{$\begin{array}{l}\text { Other } \\
\text { Flux (\%) }\end{array}$} & \multirow[b]{2}{*}{$\begin{array}{l}\text { Total } \\
\text { Flux }\end{array}$} \\
\hline & & & & Flux (\%) & & & & & \\
\hline III-1 & Oct $26(300)$ & 23 & 0 & 0 & 1 & 1 & 0 & 0 & 2 \\
\hline III-2 & Nov 22 (327) & 23 & 0 & 0 & 0 & 0 & 0 & 0 & 0 \\
\hline III-3 & Dec 19 (354) & 23 & 1 & 0 & 0 & 4 & 0 & 0 & 5 \\
\hline III-4 & $\operatorname{Jan} 16(382)$ & 23 & 1 & 0 & 3 & 4 & 1 & 0 & 9 \\
\hline III-5 & Feb 12 (409) & 23 & 0 & 0 & 0 & 0 & 0 & 0 & 0 \\
\hline III-6 & Mar 11 (436) & 23 & 0 & 0 & 0 & 0 & 0 & 0 & 0 \\
\hline III-7 & Apr 07 (463) & 23 & 0 & 3 & 1 & 0 & 0 & 0 & 4 \\
\hline III-8 & May 04 (490) & 23 & 0 & 1 & 1 & 0 & 0 & 0 & 2 \\
\hline III-9 & May 31 (517) & 23 & $22(88.0)$ & $2(8.0)$ & $1(4.0)$ & $0(0.0)$ & $0(0.0)$ & $0(0.0)$ & 25 \\
\hline III-10 & Jun 27 (544) & 23 & $65(51.2)$ & $28(22.0)$ & $19(15.0)$ & $13(10.2)$ & $1(0.8)$ & $1(0.8)$ & 127 \\
\hline III-11 & Jul 24 (571) & 23 & $52(66.7)$ & $9(11.5)$ & $7 \quad(9.0)$ & $6 \quad(7.7)$ & $4(5.1)$ & $0(0.0)$ & 78 \\
\hline III-12 & Aug 20 (598) & 23 & $62(66.7)$ & $19(20.4)$ & $9 \quad(9.7)$ & $3 \quad(3.2)$ & $0(0.0)$ & $0(0.0)$ & 93 \\
\hline \multirow[t]{2}{*}{ III-13 } & Sep $16(625)$ & 23 & $75(69.4)$ & $4(3.7)$ & $22(20.4)$ & $0 \quad(0.0)$ & $3(2.8)$ & $4(3.7)$ & 108 \\
\hline & Totals & & $278(61.4)$ & $66(14.6)$ & $64(14.1)$ & $31 \quad(6.8)$ & $9(2.0)$ & $5(1.1)$ & 453 \\
\hline
\end{tabular}


IP

\begin{tabular}{|c|c|c|c|c|c|c|c|}
\hline \multirow{2}{*}{$\begin{array}{l}\text { IP } \\
\text { cup }\end{array}$} & \multirow{2}{*}{$\begin{array}{c}\text { Date cup } \\
\text { opens } \\
\text { (1988-1989) } \\
\text { (JD) }\end{array}$} & \multirow{2}{*}{$\begin{array}{l}\text { Time } \\
\text { correction } \\
\text { factor } \\
\text { (days) }\end{array}$} & \multirow{2}{*}{$\begin{array}{l}N . \text { pachyderma } \\
\text { (left) }\end{array}$} & G. quinqueloba & $\begin{array}{l}\text { N. pachyderma } \\
\text { (right) }\end{array}$ & Other & \multirow[b]{2}{*}{ Total Flux } \\
\hline & & & & $\overline{\text { Flux (\%) }}$ & $\overline{\text { Flux (\%) }}$ & $\overline{\text { Flux (\%) }}$ & \\
\hline III-1 & Oct 21 (295) & 25 & $1(7.1)$ & $13(92.9)$ & $0(0.0)$ & $0 \quad(0.0)$ & 14 \\
\hline III-2 & Nov 17 (322) & 25 & $6(16.7)$ & $27(75.0)$ & $3(8.3)$ & $0 \quad(0.0)$ & 36 \\
\hline III-3 & Dec 14 (349) & 25 & 0 & 7 & 0 & 0 & 7 \\
\hline III-4 & Jan $11(377)$ & 25 & 0 & 3 & 0 & 0 & 3 \\
\hline III-5 & Feb 07 (404) & 25 & 1 & 1 & 0 & 0 & 2 \\
\hline III-6 & Mar 06 (431) & 25 & 0 & 1 & 1 & 1 & 3 \\
\hline III-7 & Apr 02 (458) & 25 & 1 & 0 & 0 & 0 & 1 \\
\hline III-8 & Apr 29 (485) & 25 & $12(80.0)$ & $3(20.0)$ & $0(0.0)$ & $0(0.0)$ & 15 \\
\hline III-9 & May $28(514)$ & 25 & $50(92.6)$ & $0(0.0)$ & $4(7.4)$ & $0(0.0)$ & 54 \\
\hline III-10 & Jun 22 (539) & 25 & $73(85.9)$ & $6(7.1)$ & $6(7.1)$ & $0(0.0)$ & 85 \\
\hline III-11 & Jul 19 (566) & 25 & $99(83.2)$ & $4(3.4)$ & $3(2.5)$ & $13(10.9)$ & 119 \\
\hline III-12 & Aug 15 (593) & 25 & $149(90.9)$ & $1(0.6)$ & $4(2.4)$ & $10(6.1)$ & 164 \\
\hline \multirow[t]{2}{*}{ III-13 } & Sep $11(620)$ & 25 & $2282(95.6)$ & $56 \quad(2.3)$ & $47(2.0)$ & $3(0.1)$ & 2388 \\
\hline & Totals & & $2674(92.5)$ & $122(4.2)$ & $68(2.4)$ & $27 \quad(0.9)$ & 2891 \\
\hline
\end{tabular}


APPENDIX II: The "mask" data for the SST distributions in Figures 16-18, containing the number of true (i.e. cloud-free) satellite observations used to calculate the temperature value at each grid point. Values of zero signify interpolated data. 


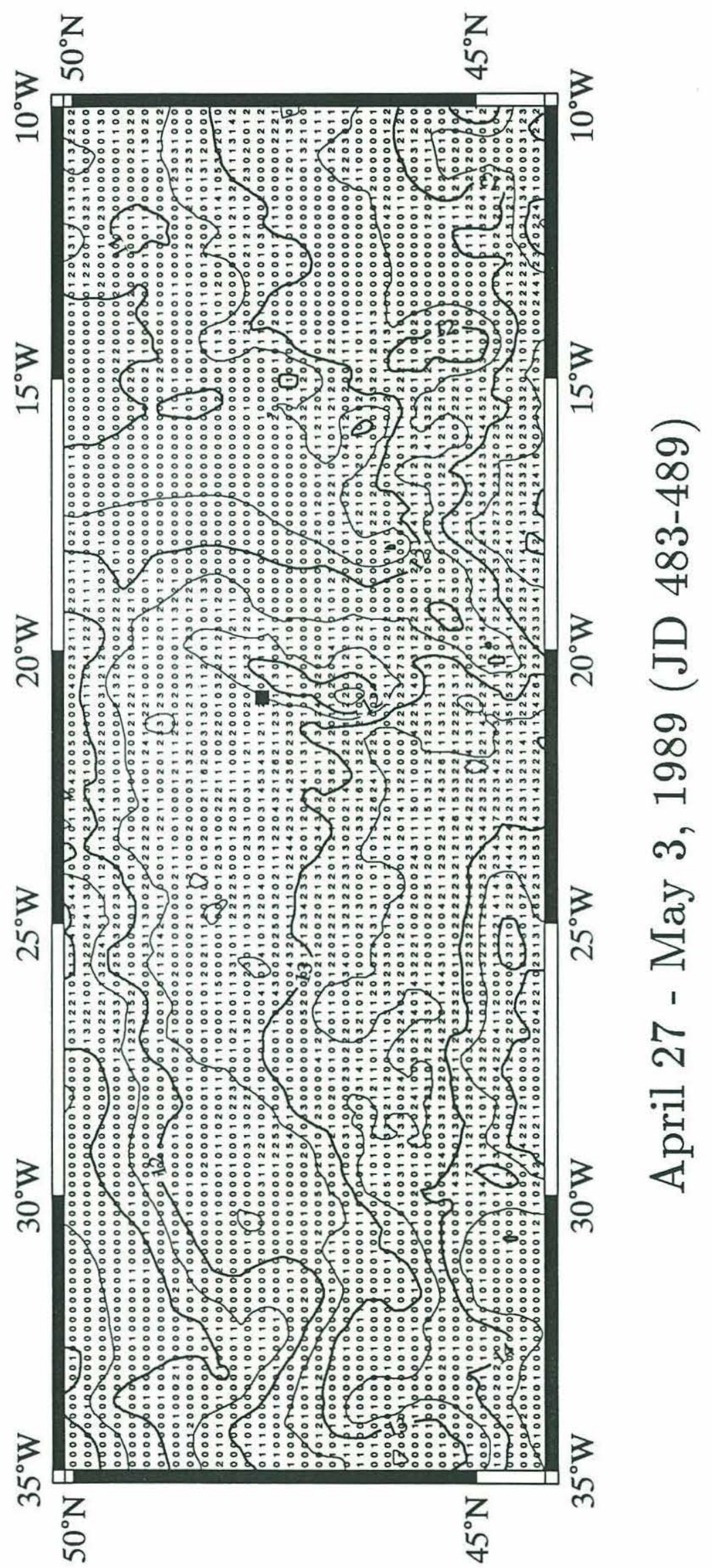




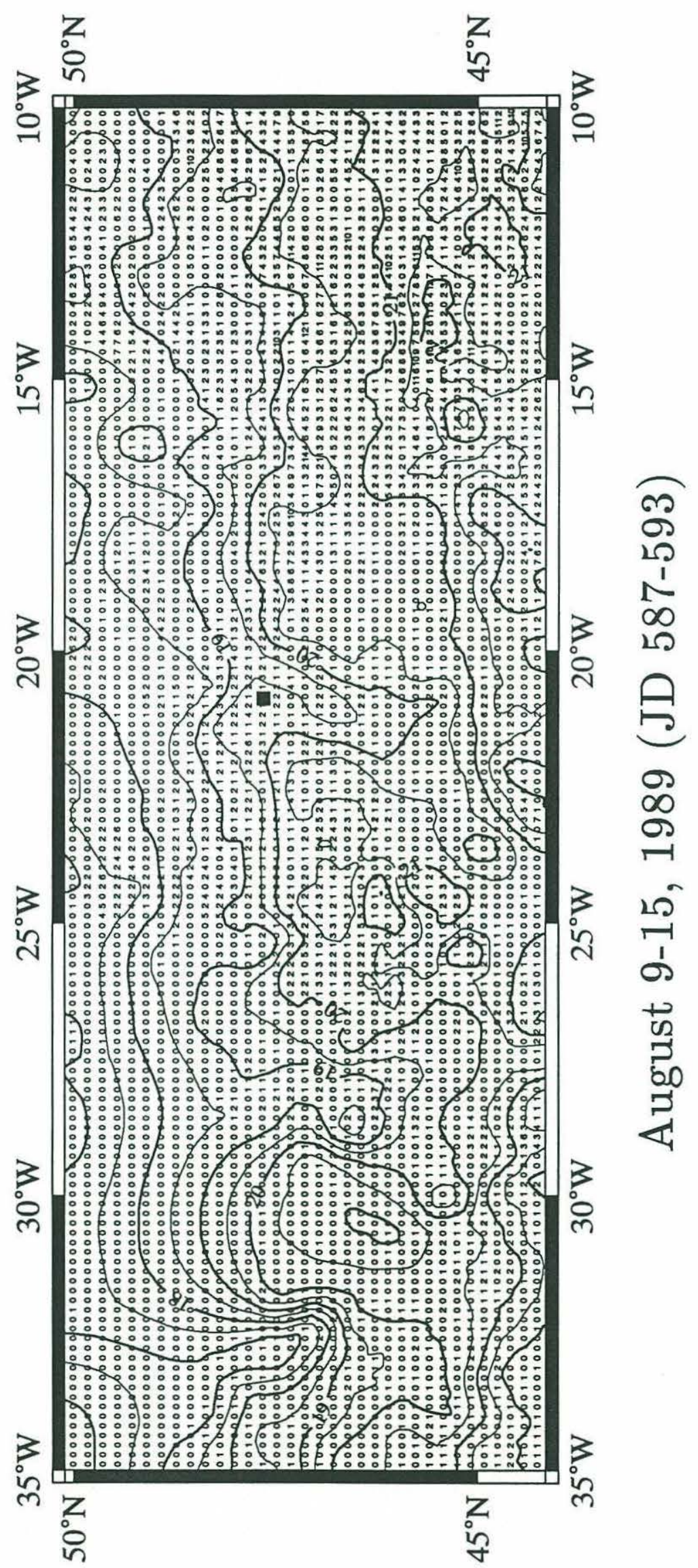




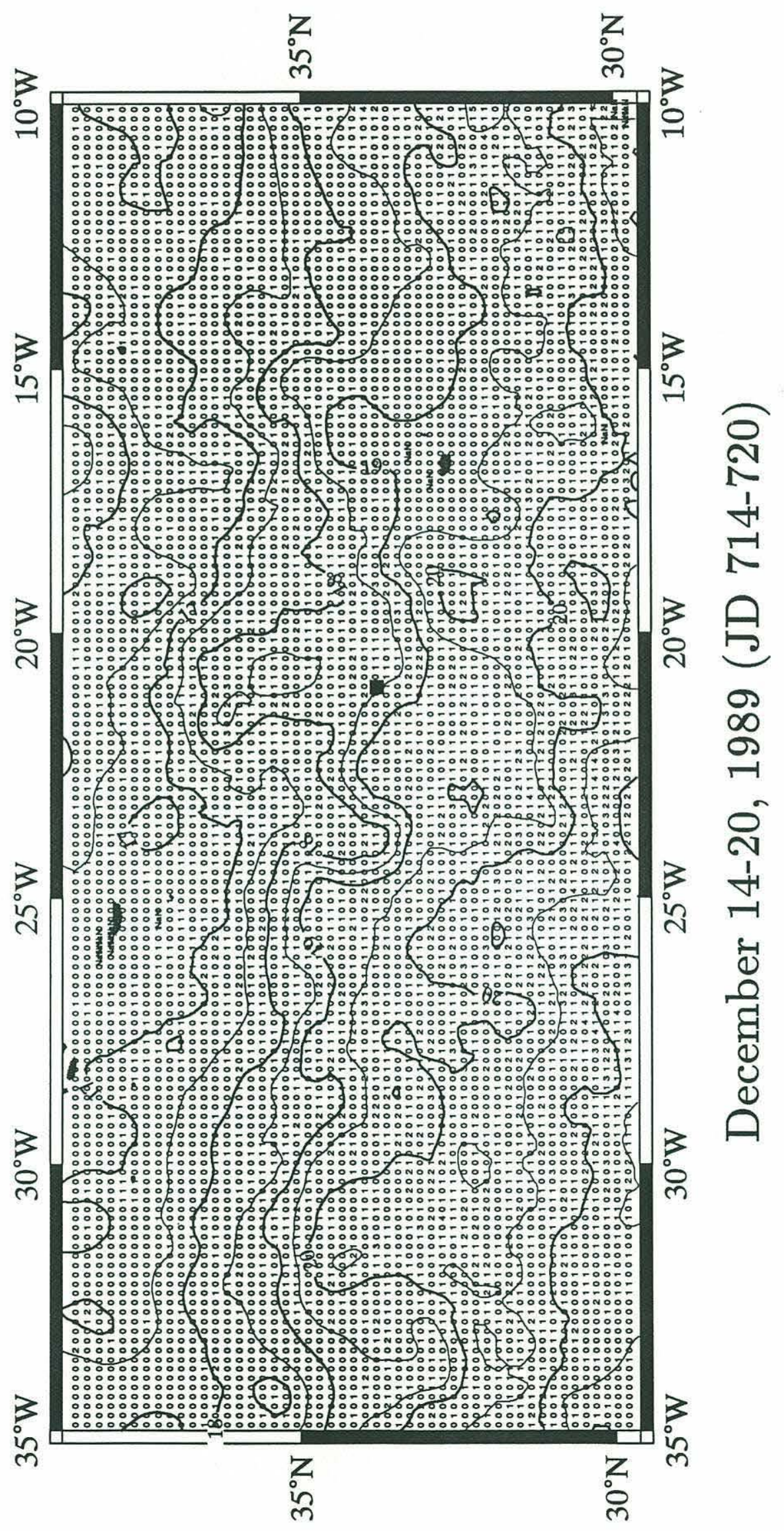




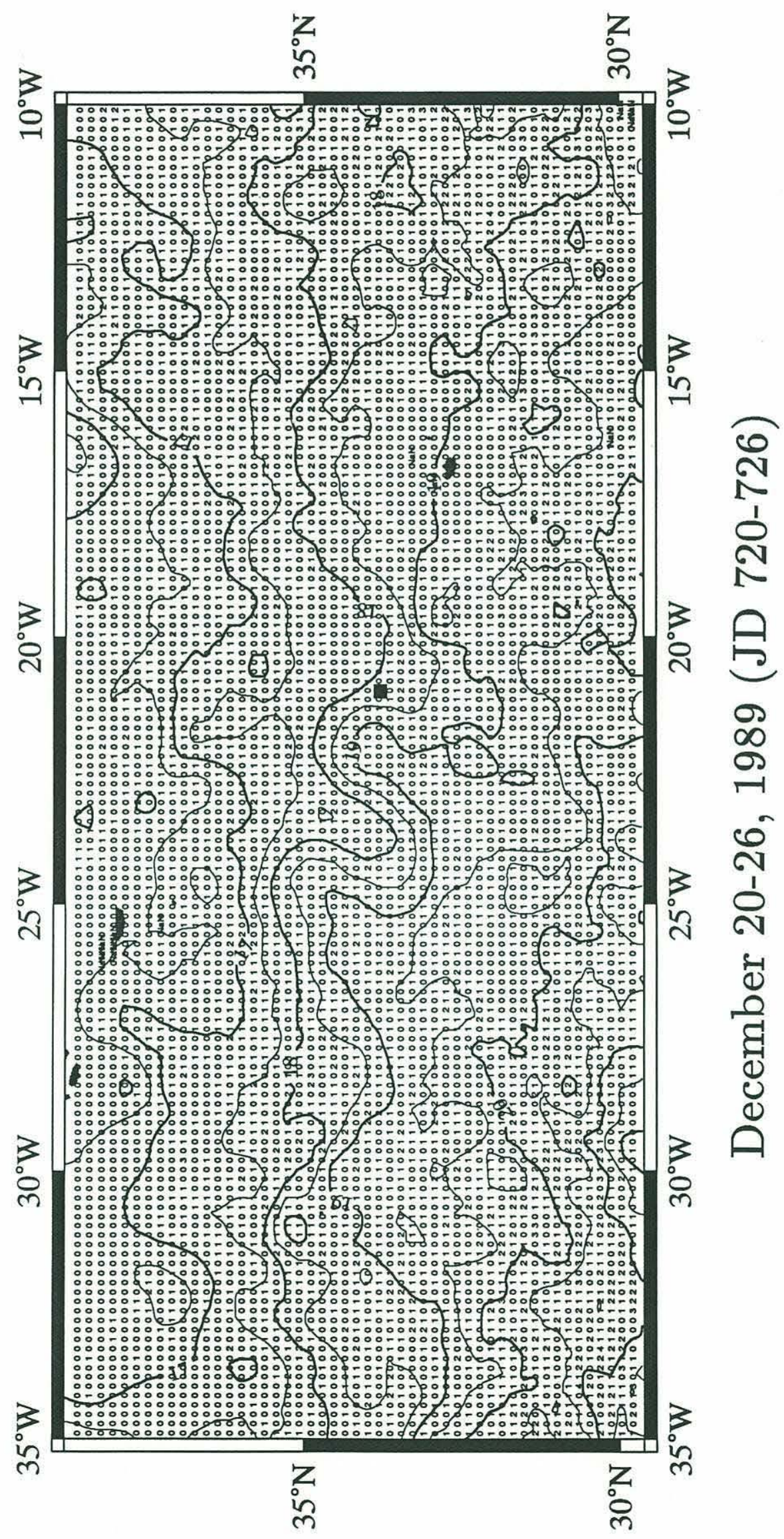




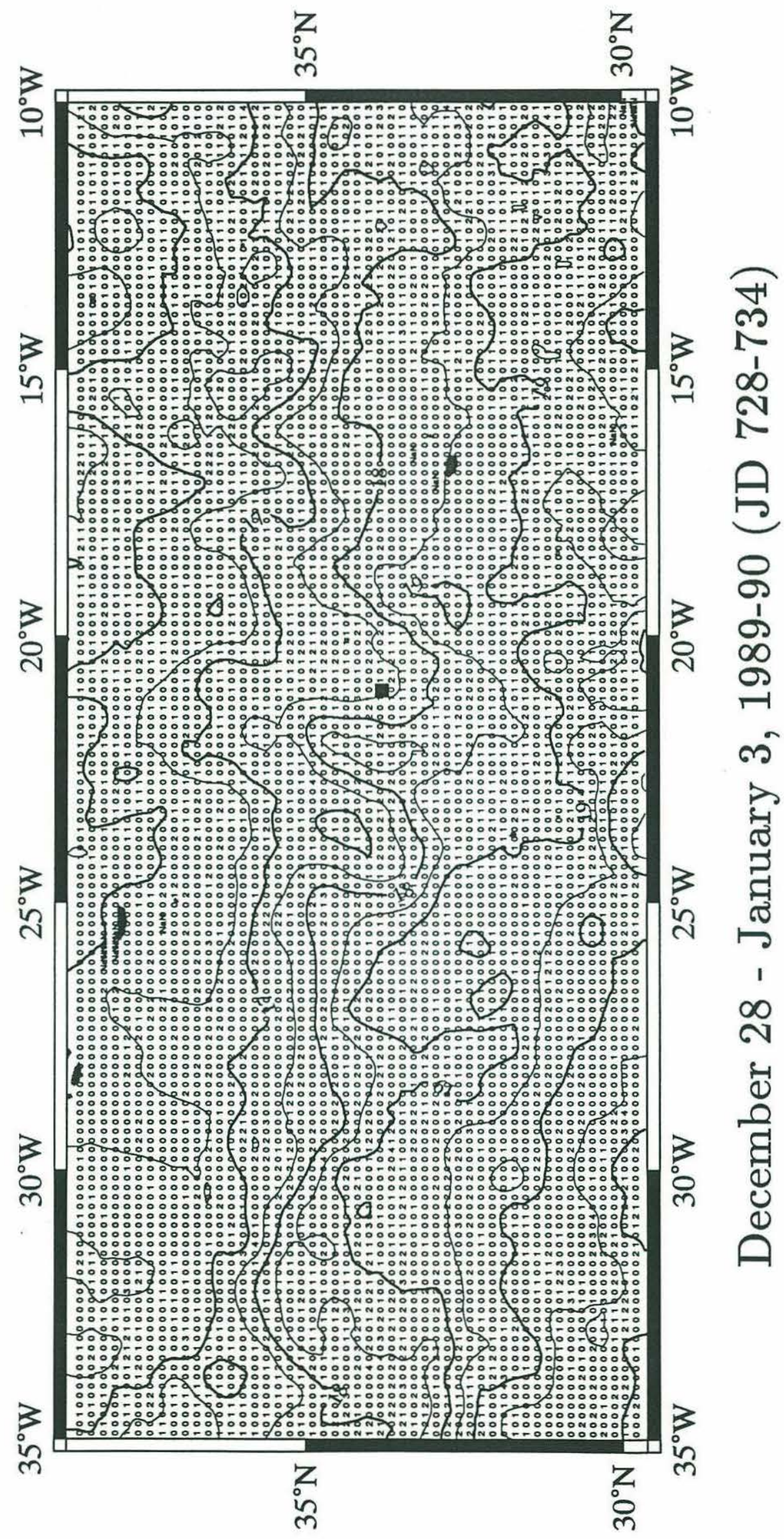




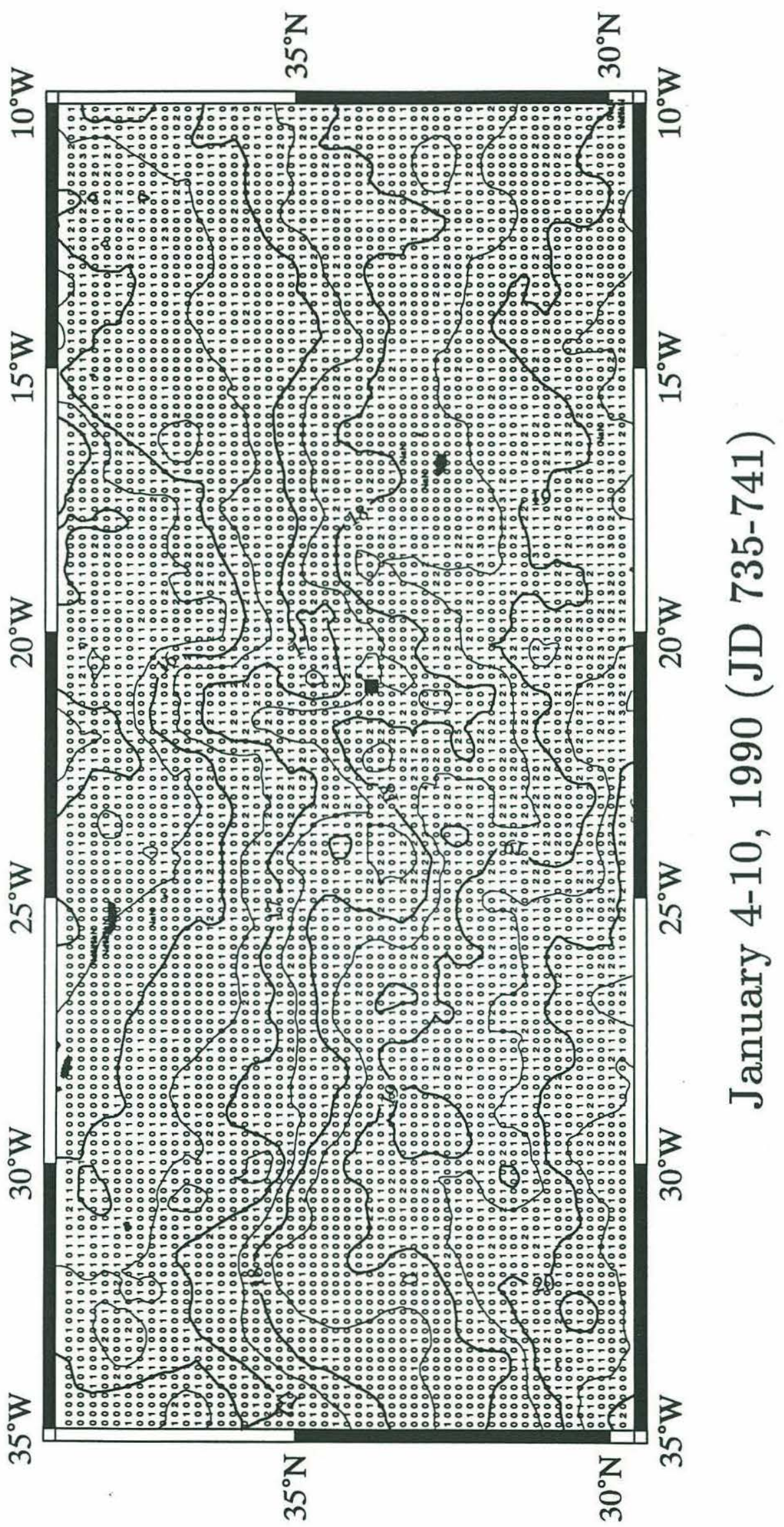




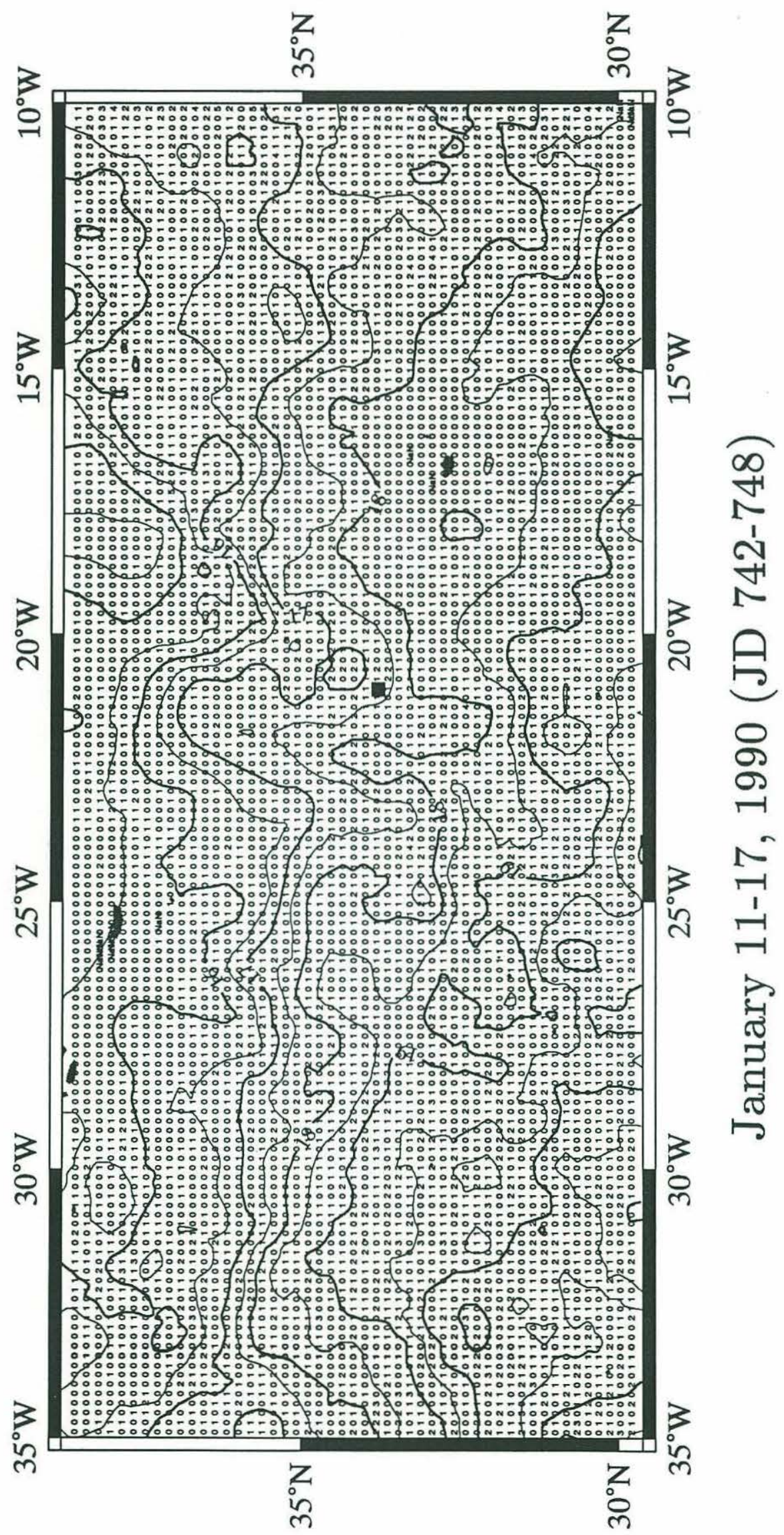




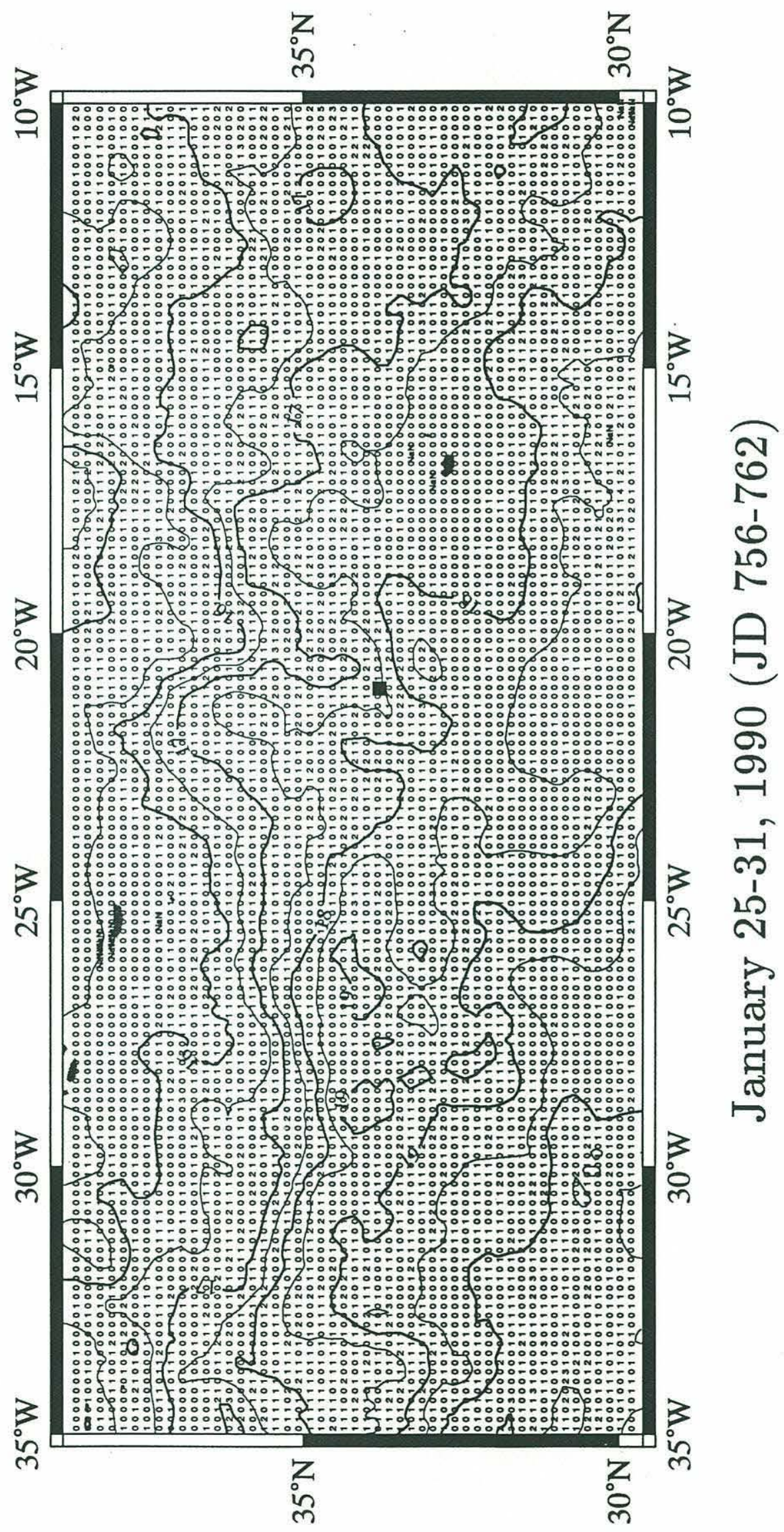




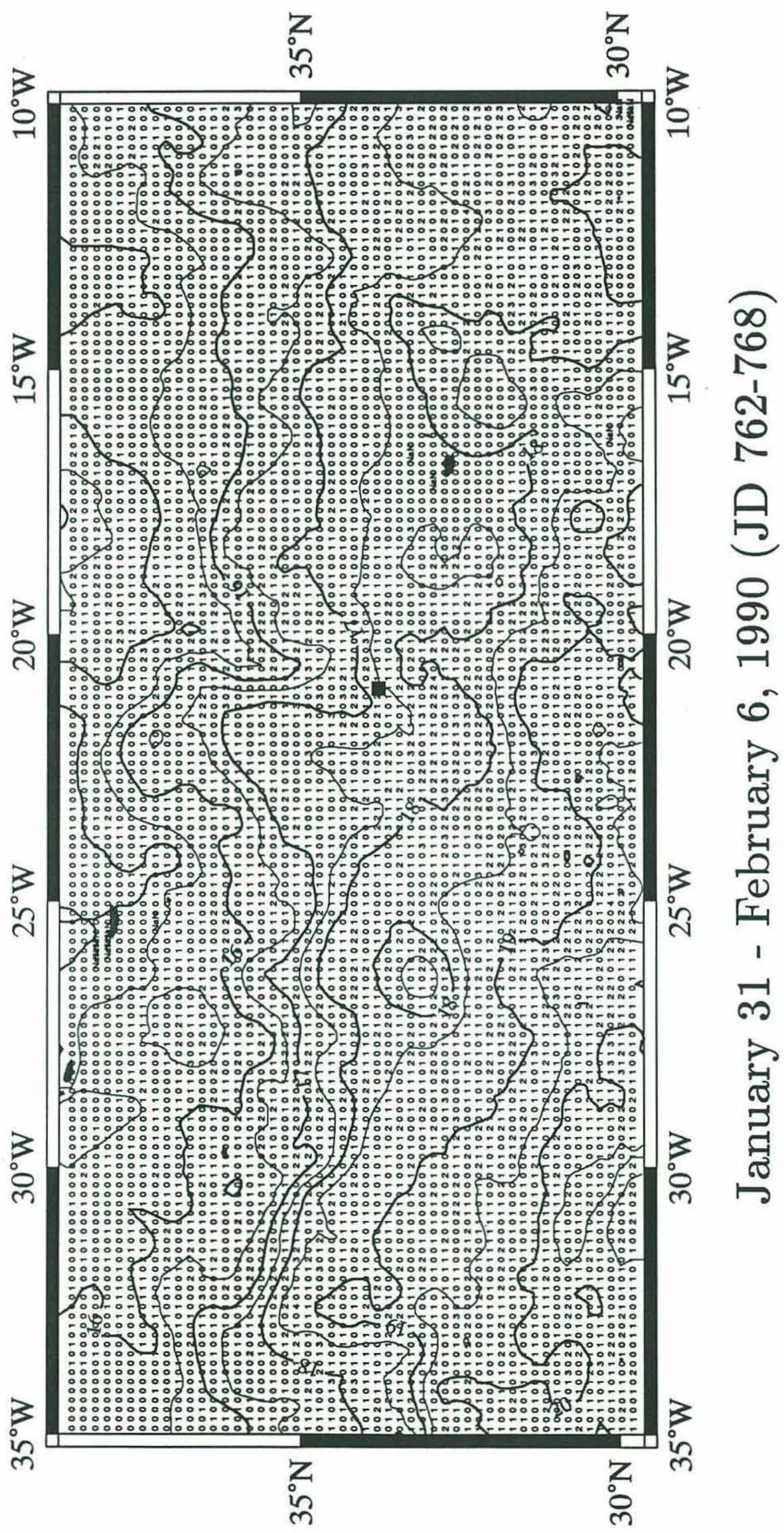




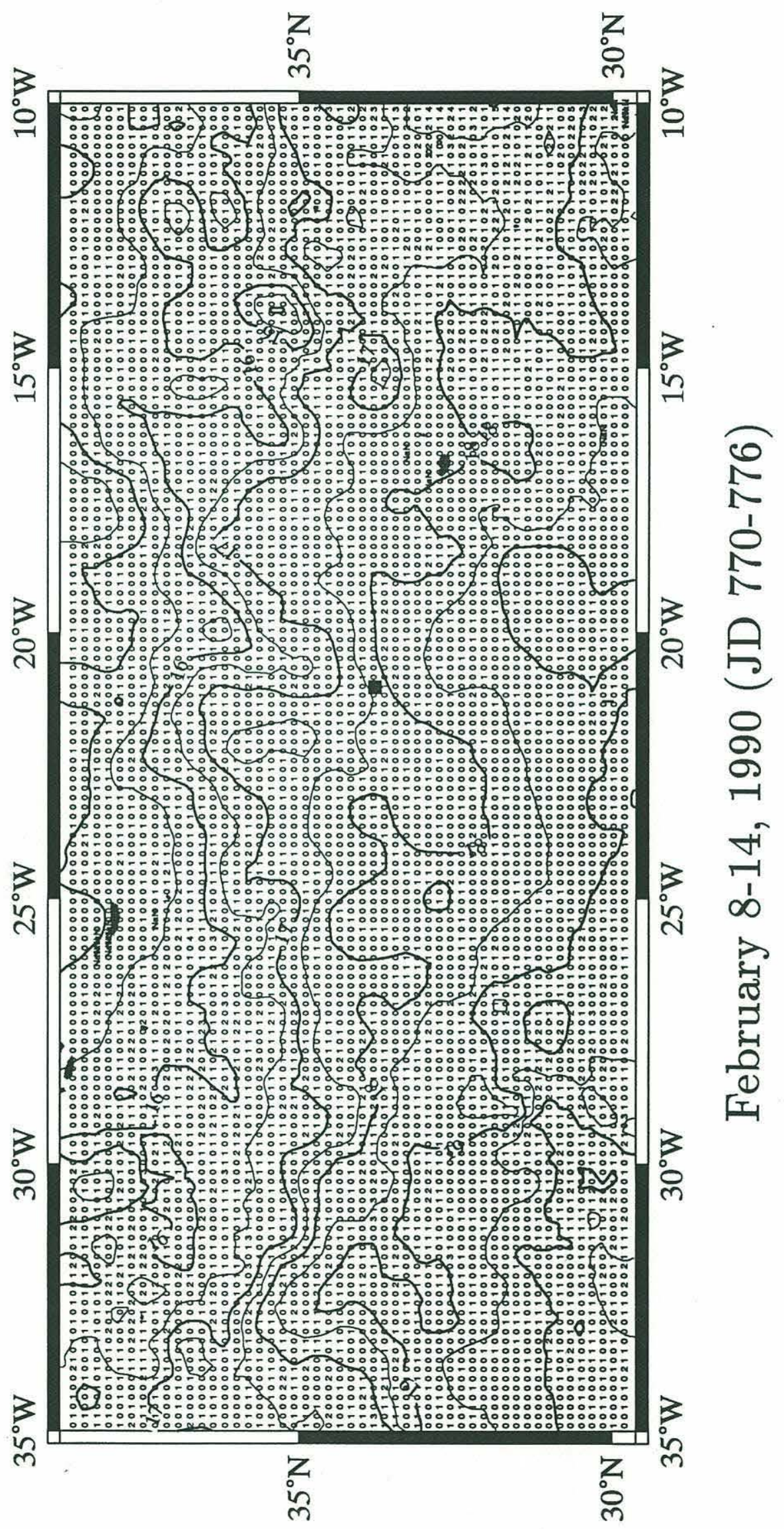


